\title{
¿UNIDAD LÓGICA O DINÁMICA? COHERENCIA Y SISTEMA JURÍDICO EN KELSEN *
}

\author{
Miguel Ángel Rodilla \\ Universidad de Salamanca
}

RESUMEN. En el tratamiento kelseniano del problema de los conflictos entre normas aflora una tensión entre una concepción del Derecho como un sistema dinámico de normas positivas y una concepción del sistema jurídico como una "unidad lógica», lo que implica, entre otras cosas, ausencia de contradicciones. En este artículo se analiza la evolución del pensamiento de KELSEN a propósito del tema, identificando tres posiciones sucesivas, y se examina la estrategia teórica que siguió el autor para defender casi hasta el final de su vida la tesis según la cual la coherencia es una propiedad necesaria del sistema jurídico, y las razones por las cuales terminó por abandonarla.

Palabras clave: KELSEN, sistema jurídico, conflictos de normas, antinomias.

ABSTRACT. Looking at the Kelsenian approach to the conflicts of norms, we can detect a tension between the understanding of law as a dynamic system of positive norms and the interpretation of the legal system as a «logical unity», which implies, among other things, a complete lack of normative contradictions. In this essay, the evolution of KELSEN'S thought respecting this issue is analyzed and three consecutive positions are identified. The theoretical strategy followed by him defending, almost until the end of his life, the thesis according to which coherence is a necessary property of a legal system is examined, and the reasons behind his abandonment of that thesis are unveiled.

Keywords: KELSEN, legal system, conficts of norms, antinomies.

* Fecha de recepción: 28 de septiembre de 2009. Fecha de aceptación: 29 de octubre de 2009.

Este trabajo estaba destinado a incorporarse al libro colectivo preparado como homenaje a G. PECESBARBA con ocasión de su jubilación. Diversas circunstancias me impidieron terminarlo a tiempo. Si ahora se lo dedico a él es como una forma de unirme, con retraso pero con todo afecto, a ese merecido homenaje. J. DELgado Pinto, J. Ruiz Manero, J. A. Ramos Pascua, J. M. Pérez Bermejo, J. M. ${ }^{a}$ Garrán, L. Santos Pérez, J. A. SENDín, E. RojAS y J. BENFELD leyeron y discutieron el borrador. Les estoy muy agradecido por sus observaciones. Recientemente he vuelto a leer «El voluntarismo de Hans Kelsen y su concepción del orden jurídico como un sistema normativo dinámico», publicado por el profesor DELGADO PINTO en 1977 y ahora reeditado en sus Estudios de Filosofía del Derecho, Madrid, CEPC, 2006, sobre el que lamentablemente no había vuelto desde hacía mucho tiempo. Esa nueva lectura me ha hecho caer en la cuenta de cuánto debe mi trabajo a las ideas desarrolladas en ese escrito: desde la distancia de una treintena de años esas ideas han debido de estar trabajando, por así decirlo, en la trastienda, sin que yo fuera consciente de ello. Estoy seguro de que el resultado habría sido mejor si en el momento de redactar estas páginas hubiera tenido más presente ese escrito. Este trabajo se ha realizado en el marco del proyecto de investigación SEJ20007-63792 financiado por la DGI. 


\section{A Gregorio Peces-Barba}

\section{INTRODUCCIÓN}

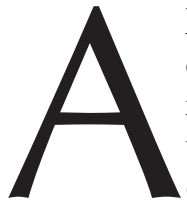

1 comienzo de la segunda parte de su conocido e influyente libro sobre el positivismo jurídico, N. BOBBIO esboza una caracterización inicial formulando nada menos que siete «puntos básicos» que constituirían otras tantas tesis características del positivismo. Yo me inclino a pensar que lo que denominamos «positivismo jurídico» es un movimiento abigarrado integrado por corrientes muy diversas que comparten muy pocas tesis — desde luego menos de las que enumera BовBIO- ${ }^{1}$. Pero no voy a entrar a discutir ese punto. En este momento me interesa llamar la atención sobre una tesis muy fuerte a propósito del sistema jurídico que BOBBIO incluye entre sus siete «puntos básicos»:

«El positivismo jurídico afirma la teoría de la coherencia y la plenitud del Ordenamiento jurídico: a) la característica de la coherencia excluye que en un mismo Ordenamiento jurídico puedan coexistir simultáneamente dos normas antinómicas (contradictorias o contrarias), porque se considera implícito en él el principio según el cual una de las dos normas, o ambas, no son válidas; $b$ ) con el requisito de la plenitud el positivismo jurídico afirma que a partir de las normas explícita o implícitamente contenidas en un Ordenamiento, el juez puede siempre recabar una regula decidenci para resolver cualquier caso que se plantee: el positivismo jurídico excluye que existan lagunas en el Derecho»² ${ }^{2}$.

Ésa es, en mi opinión, una afirmación muy problemática. Para empezar, i) ocupa un lugar impreciso en la visión de BoBBIO sobre el positivismo jurídico. Peor aún, ii) tomada en sus propios términos, es sencillamente errónea.

i) Es confuso el papel que desempeña esa tesis en el tratamiento que BOBBiO ofrece del positivismo jurídico porque, como es sabido, buena parte del empeño desarrollado por él en su teoría del sistema jurídico ${ }^{3}$ se dirige precisamente a desmontar, por un lado, las versiones más importantes de la tesis de la plenitud o compleción del Derecho, y a persuadirnos, por otro, de que el sistema jurídico no sólo es propenso a albergar antinomias sino que «a pesar de la armadura de reglas con las que la labor del jurista está protegida contra el peligro de la valoración personal sobre lo que es justo e injusto, hay situaciones últimas en las que la armadura no sirve, más aún, estorba, y hay que afrontar la dificultad a pecho descubierto» ${ }^{4}$. De modo que o la doctrina sobre la coherencia y la plenitud como propiedades del sistema jurídico no está ligada al positivismo de forma necesaria o BOBBIO no puede ser incluido en las filas del positivismo, a pesar de su propia autoadscripción.

1 La verdad es que en este contexto BoBBIo se expresa de forma algo confusa: habla de siete «caracteres fundamentales» del positivismo jurídico, que pueden formularse en otros tantos «puntos o problemas». No está claro, pues, si se trata de siete tesis del positivismo o de siete temas característicos de las discusiones doctrinales del positivismo. Probablemente el catálogo de BоввіO resulta de una combinación de ambas cosas. En todo caso el «punto» que aquí interesa aparece claramente formulado como una tesis.

2 N. Bobbio, El positivismo jurídico, trad. de R. DE Asís y A. GrePPI, Madrid, Debate, 1993, p. 142.

3 Vid. la segunda parte de El positivismo jurídico, op. cit., así como la de su Teoría general del Derecho, trad. de E. Rozo AcuÑA, Bogotá, Temis, 1987 (reeditado en Debate, 1. ra reimpr., Madrid, 1991).

4 «Sobre los criterios para resolver las antinomias», en N. BOBBIO, Contribución a la teoría del Derecho, trad. de A. Ruiz Miguel, Valencia, Fernando Torres, 1980, p. 364. 
ii) Independientemente de ello, la consideración de la tesis de la compleción y coherencia del sistema jurídico como tesis característica del positivismo jurídico me parece errónea. Contra ella habla, ante todo, el hecho de que existen teorías positivistas que la rechazan. Ése es, notoriamente, el caso de HART, quien después de KELSEN ha sido probablemente el teórico del Derecho más importante del siglo XX, y el creador de una de las versiones más interesantes e influyentes de teoría positivista del Derecho. En este punto HART se conduce, creo yo, de forma enteramente consecuente. Una vez que se admite la que él denomina «tesis de las fuentes sociales del Derecho», se sigue con toda naturalidad la «tesis de la discrecionalidad judicial», de acuerdo con la cual «en todo sistema jurídico habrá siempre ciertos casos no previstos y no regulados legalmente, es decir, casos para los que ningún tipo de decisión es dictado por el Derecho claramente establecido y, en consecuencia, el Derecho es particularmente indeterminado o incompleto» ${ }^{5}$.

En realidad lo sorprendente es que las tesis de la compleción y la coherencia del sistema jurídico hayan encontrado acomodo en las filas positivistas. Si, conforme a las convicciones del positivismo, admitimos que las normas jurídicas entran en el sistema a través de hechos sociales contingentes y de actos humanos deliberados, realizados por distintas autoridades en momentos diferentes, bajo la presión de contingencias diversas y obedeciendo a propósitos muy variados, parece casi obvio que sería una feliz (e improbable) casualidad que el resultado de un trabajo así de producción normativa fuera coherente y completo. Eso sólo sería verosímil bajo la hipótesis de un legislador racional, ominisciente y providente. Pero, independientemente de la fecundidad que pueda tener esa hipótesis como postulado hermenéutico ${ }^{6}$, desde el punto de vista descriptivo hace tiempo que ha sido abandonada por el positivismo jurídico - hace ya más de un siglo que GÉNY la despachó como una ficción ingenua, que «anuda con las ilusiones racionalistas de finales del siglo XVIII en relación con el poder de la legislación escrita» ${ }^{7}$.

KELSEN puede ser cualquier cosa menos un teórico del Derecho ingenuo. Por eso sorprende que de forma enfática y sostenida defendiera a lo largo de toda su vida la tesis de la compleción del sistema jurídico, y casi hasta el final de sus días la tesis de la coherencia. No voy a discutir su doctrina a propósito de la compleción del sistema jurídico, que hace tiempo que C. ALCHOURRÓN y E. BULYGIN demostraron que descansaba en un uso sistemáticamente ambiguo del término «permitido» en el enunciado «Todo lo que no está prohibido está permitido», que KELSEN situaba como norma de clausura destinada a cerrar herméticamente el sistema jurídico impidiendo la formación de lagunas normativas ${ }^{8}$. Voy a examinar, en cambio, el pensamiento kelseniano a propósito de la coherencia del sistema y el problema de las antinomias.

5 H. L. A. HART, «El nuevo desafío al positivismo jurídico», trad. por L. HierRo, F. LAPORTA y J. R. PÁRAMO, Sistema, 36 (mayo 1980), p. 5. Junto con la «tesis de la separación conceptual del Derecho y la moral», esas dos tesis forman parte, según HART, del núcleo básico de una teoría positivista del Derecho — de la suya al menos.

6 Sobre el «modelo dogmático del legislador», vid. C. S. NiNO, Introducción al análisis del Derecho, Barcelona, Ariel, 1983, pp. 328 y ss. Vid. también, Fr. OST y M. VAN DER KERCHOVE, «Rationalité et souveraineté du législateur, "paradigmas" de la dogmatique juridique?», RIFD, 62 (1985), y M. CALVO GARCÍA, «Metodología jurídica e interpretación: El postulado de la racionalidad del legislador», AFD (n. e.) 3 (1986).

7 F. GÉNY, Méthode d'interpretation et sources en droit privé positif, 2. ${ }^{a}$ ed., Paris, LRDJ, 1954, \$96.

8 Vid. el cap. VIII de Introducción a la metodología de las ciencias jurídicas y sociales, 1975, 2. ${ }^{a}$ reimpr. Buenos Aires, Astrea, 1993. Para una interesante discusión reciente sobre el tema de las lagunas me remito a F. 
En este punto el examen del pensamiento kelseniano es particularmente instructivo, porque a lo largo de su dilatada trayectoria intelectual KELSEN defendió dos doctrinas opuestas. Durante la mayor parte de su vida atribuyó de forma enérgica al sistema jurídico la propiedad lógica de la ausencia de contradicciones, lo que le indujo a sostener que todo sistema jurídico contiene un conjunto de reglas no convencionales que aseguran la coherencia. A partir de una fecha relativamente tardía pasó, en cambio, a sostener, con la misma energía, que la coherencia es tan sólo una propiedad deseable del sistema jurídico, de modo que los sistemas jurídicos están en condiciones de asegurarse coherencia sólo en la medida en que dispongan de reglas positivas capaces de disolver las incoherencias. En el primer caso el Derecho es un sistema necesariamente coherente; en el segundo la coherencia es un mero desideratum: un sistema jurídico sería coherente sólo de forma contingente, y, por cierto, improbable.

\section{CONFLICTOS ENTRE NORMAS}

Antes de pasar a analizar la(s) doctrina(s) de KELSEN a propósito de la coherencia del sistema jurídico es conveniente preparar el terreno explorando la idea misma de conflicto entre normas. La exploración que se hace a continuación sigue el camino bien trillado de la definición de antinomia, y el lector informado puede sencillamente saltarla y pasar directamente a la sección 2. Con todo, puede que no esté enteramente de más, en la medida en que permita destacar algunas peculiaridades de la caracterización que el mismo KELSEN ofrece de las antinomias o conflictos (lógicos) entre normas.

\section{1. ¿Qué coherencia?}

Empecemos acotando el terreno en que vamos a movernos, indicando el sentido en que vamos a discutir si el sistema jurídico es coherente. Esto es necesario ya que, aplicada a sistemas normativos, la exigencia de coherencia puede entenderse en sentidos diferentes. En un primer sentido podemos decir que un sistema normativo es coherente cuando las normas que lo integran están relacionadas unas con otras mediante operaciones de inferencia correctas. Coherencia en este sentido puede (y debe) exigirse de sistemas normativos estáticos, que, de acuerdo con la caracterización de KELSEN ${ }^{9}$, están integrados por normas conectadas unas con otras y en último término con la norma fundamental del sistema mediante relaciones estrictamente deductivas: «las diversas normas de un sistema de este tipo se encuentran implicadas por la norma fundamental del mismo modo que lo particular está implicado por lo general, y [...] por consiguiente, todas las normas particulares de semejante sistema pueden obtenerse

\footnotetext{
ATRIA y otros, Lagunas en el Derecho. Una controversia sobre el Derecho y la función judicial, Madrid, Marcial Pons, 2005.

9 Para la distinción entre sistemas estáticos y dinámicos vid. PG 290 y ss., TP1 94 y ss., TP2 135 y ss., GT 110 y ss. [129 y ss.] , RR 198 y ss. [203 y ss.]. Como es sabido, el tema desaparece enteramente en TGN por motivos que examina L. GiARFORMAGGIO en «¿Qué queda en la Allgemeine Theorie der Normen de los sistemas normativos estáticos y dinámicos», ahora en Estudios sobre Kelsen, México, Fontamara, 1994. Sobre la significación de esa distinción kelseniana es muy instructiva la obra colectiva coordinada por la misma L. GIANFORMAGGIO, Sistemi normativi statici e dinamici. Analisi di una tipologia kelseniana, Torino, Giapichelli, 1991.
} 
mediante una operación intelectual, es decir, mediante la inferencia de lo general a lo particular» (GT 112 [131 y ss.]). Así, por ejemplo, en un sistema moral del tipo de los que pretendieron construirse en la época de la Ilustración bajo el rótulo «Derecho natural» incurriríamos en incoherencia si le atribuimos normas que no pueden deducirse de la norma fundamental del sistema, aunque propiamente no sean incompatibles ${ }^{10}$. Ahora bien, según la caracterización kelseniana el Derecho es un sistema normativo dinámico, es decir, un sistema cuyas normas no valen por su contenido sino

«en virtud del hecho de haber sido creadas[s] de acuerdo con una regla definida, y sólo por ello [...] La norma fundamental de un orden jurídico positivo no es sino la regla fundamental de acuerdo con la cual han de crearse las diversas normas de ese orden. Cualifica un determinado acontecimiento como el acontecimiento inicial en la creación de las diversas normas jurídicas. Es el punto de partida de un proceso de creación de normas [...] Las normas individuales del orden jurídico no pueden ser deducidas lógicamente de esa norma fundamental [...] Tienen que ser creadas por un acto volitivo especial, no inferidas (concluded) de una premisa en virtud de una operación intelectual» [GT 113 y ss. (133 y ss.), cursivas mías; en términos parecidos TP1 96 y ss.].

En estas condiciones está fuera de lugar exigir al Derecho coherencia en sentido deductivo ${ }^{11}$. Podemos, en cambio, exigirle coherencia en el sentido más débil de «compatibilidad»: un sistema jurídico no es coherente si contiene normas incompatibles.

Ahora bien, en un sistema jurídico pueden presentarse incompatibilidades e incoherencias de diversos tipos. Siguiendo a K. ENGISCH, pueden distinguirse al menos cinco clases de incoherencias jurídicas ${ }^{12}$ : a) se producen incoherencias técnico-legales por falta de unidad terminológica, esto es, cuando existen inconsistencias en el uso de términos presentes en varias normas; b) existen incoherencias teleológicas cuando hay normas que persiguen fines en conflicto; $c$ ) existen incoherencias de principio cuando los principios que inspiran las normas del sistema están en conflicto; $d$ ) existen in-

10 Si construimos un sistema moral tomando como primer principio «No hagas a tu prójimo lo que no quieras que se haga contigo», preceptos morales bien conocidos, como «No insultar», «No mentir», «No robar», y otros por el estilo, pueden considerarse coherentes entre sí porque todos ellos pueden inferirse de ese primer principio. En cambio la norma «No inflijas sufrimiento innecesario a los animales» es incoherente con ellos, en el sentido de que no puede derivarse del primer principio (a menos que, con Francisco de Asís, consideremos a los animales hermanos nuestros), y por ello no puede formar parte del sistema, a pesar de que es difícil decir que es incompatible o contradictoria con el resto de las normas del sistema —más bien, al contrario, podríamos decir que es «consonante» con ellas.

11 Vid. J. WRÓBLEWSKI, «Systems of norms and legal norms», RIFD, 49 (1972), pp. 234 y ss. Tal vez no esté de más añadir que KELSEN no parece excluir que la coherencia en sentido deductivo tiene un cierto papel también en un sistema jurídico — a saber, en la relación que se da entre normas generales y normas individuales (v. $g r$. sentencias) en el marco de la aplicación jurisdiccional del Derecho-. En este punto es significativo que, cuando en un momento tardío de su trayectoria intelectual revisa su concepción sobre el lugar de lógica en el Derecho, reconoce que «desde siempre» la teoría pura del Derecho había admitido la aplicabilidad de «los principios lógicos, especialmente el principio de contradicción y las reglas de inferencia lógica a la relación en-

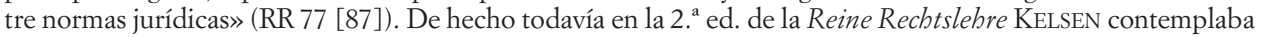
la posibilidad de obtener normas particulares mediante operaciones de inferencia lógica a partir de normas generales (aunque indirectamente: sirviéndose de las proposiciones que describen las normas). El cap. 58 de la Allgemeine Theorie der Normen está dirigido a eliminar esa posibilidad.

12 Einführung in das juristischen Denken, Kohlhammer, Stuttgart, 1956m, pp. 157 y ss. [Introducción al pensamiento jurídico, trad. de E. GARZón VALDÉs, Madrid, Guadarrama, 1967, pp. 198 y ss.] (en realidad ENGISCH habla de «contradicciones»; por razones que se entenderán inmediatamente, prefiero hablar de incoherencias). Desde otro punto de vista, es instructivo H. HAMNER HILL, «A functional taxonomy of normative conflicts», en Law and Philosophy, 6 (1987), pp. 227 y ss. Vid. también T. MAZZARESE, «Antinomie, paradossi, logica deontica», en RIFD, 61 (1984) pp. 419 y ss. 
coherencias valorativas cuando, a la luz de las consecuencias jurídicas que el sistema atribuye a determinados hechos o acciones, se revelan inconsistencias en la valoración que el legislador hace de ellos; e) finalmente existen incoherencias normativas cuando varias normas del sistema regulan de forma lógicamente incompatible la conducta de las personas, de modo que la misma conducta ${ }^{13}$ «aparece al mismo tiempo como mandada y no mandada, prohibida y no prohibida o incluso mandada y prohibida» ${ }^{14}$. En este último caso las normas son lógicamente incoherentes porque «el cumplimiento de una de ellas excluye, por razones lógicas, el cumplimiento de la otra» ${ }^{15}$; en estas condiciones, la conducta afectada por el sistema jurídico está, por así decirlo, sobredeterminada, pero lo está de modo incompatible, pues en ese caso «toda conducta es a la vez conforme y contraria al sistema» ${ }^{16}$.

A este último tipo de incoherencia suele referirse KELSEN con la expresión «conflicto entre normas». En la última de las definiciones que nos ofrece del mismo lo presenta en los siguientes términos:

«Existe un conflicto de normas cuando una norma establece como debida una conducta, mientras la otra establece como debida la omisión de esa conducta [...] La situación creada en un conflicto de normas consiste en que si se sigue una de las dos normas en conflicto, se viola la otra...» (ATN 168, en términos parecidos GN, 870 y ss.).

De forma significativa, en el opúsculo El contrato y el tratado (1945) KeLSEN precisó su objeto agregando el calificativo de «lógico» ${ }^{17}$, e introduciendo de paso la distinción entre conflictos «lógicos» entre normas y conflictos «teleológicos»: «nos hallamos en presencia de un conflicto lógico cuando una norma estatuye el contenido $a$ y otra norma del mismo sistema estatuye el contenido no $a$; por ejemplo, no

13 Para ser exactos, he de puntualizar que ENGISCH habla de «conducta in abstracto o in concreto» (ibid.). Con ello proporciona una definición que en mi opinión es insatisfactoria, porque no permite distinguir entre un conflicto lógico entre normas (antinomia), que se da cuando no es posible formular las dos normas sin incurrir en contradicción lógica, y un conflicto de deberes, que puede producirse cuando la aplicación de dos normas lógicamente compatibles, en las circunstancias concretas del caso, produce exigencias inconsistentes. Precisamente el caso que ENGISCH aduce como ejemplo de «contradicción normativa»—el orden jurídico ordena cumplir incondicionalmente la orden de un superior y al mismo tiempo prohíbe realizar determinadas acciones - no es un caso de antinomia, aunque para el destinatario de la norma «circunstancialmente» (ibid.) pueda representar un conflicto de deberes — si, por ejemplo un superior le ordena matar a un inocente-. Creo que es esto lo que J. WRÓBLEWSKI denomina «inconsistencia concreta» (vid. «Systems of norms and legal norms», op. cit., p. 244) y St. MÜNZER, «Conflicto en una ocasión particular» [vid. «Validity and legal conflicts», Yale Law Journal, 82 (1973)]. W. MaLGAUD habla en este caso de «antinomia accidental» («Les antinomies en droit, à propos de l'étude de Gavazzi», en Ch. PERELMAN, Les antinomies en droit, Bruxelles, Bruylant, 1965, p. 18), y A. ConTE de «Paradoja proerética» [Nove Studi sul linguaggio normativo (1967-1978), Giappichelli, Torino, 1985, pp. 133 y ss.]. Aunque por comodidad prefiero servirme de la denominación de «paranomia» utilizada por T. MAZZARESE, «Antinomie, paradossi, logica deontica», en RIFD, 61 (1984), pp. 422 y ss.), y T. Ausín (Entre la lógica y el Derecho. Paradojas y conflictos normativos, Barcelona, Plaza y Valdés, 2005, pp. 133 y ss.), probablemente es C. ALCHOURRÓN quien ofrece la caracterización más precisa del fenómeno bajo la denominación de «inconsistencia normativa condicional» (vid. «Conflictos de normas y revisión de sistemas normativos», ahora reeditado en C. AlCHOURRÓn y E. BulYgIn, Análisis lógico y Derecho, Madrid, CEC, 1991).

14 Einfübrung ..., op. cit., p. 158.

15 C. E. AlchourRón y E. Bulygin, «Sobre el concepto de orden jurídico», en Análisis lógico y Derecho, Madrid, Centro de Est. Const., 1991, p. 407.

16 Ibid., p. 406.

17 Que en el pasaje de ATN que acabo de acotar no aparezca ese calificativo se entenderá sin dificultad a lo largo de estas páginas. En realidad en el párrafo al que pertenece este pasaje KELSEN se propone defender que los conflictos entre normas no son contradicciones, es decir, conflictos lógicos. 
debes matar nunca y debes en caso de guerra matar a los enemigos [...] El conflicto puramente teleológico aparece cuando el contenido de dos normas no es lógicamente incompatible, porque es posible formularlo en dos frases que no implican una contradicción lógica [...] pero [...] la ejecución de una de las dos normas significa un perjuicio para el fin presunto de la otra» (CT 85 y ss. ${ }^{18}$. Los conflictos lógicos y los conflictos teleológicos son de naturaleza diferente, y de la presencia de uno u otro tipo de conflicto derivan consecuencias diferentes para la existencia de las normas y su pertenencia al sistema: en el caso de un conflicto teleológico las dos normas conservan su validez y deben ser aplicadas; en cambio dos normas lógicamente incompatibles no pueden coexistir, «se destruyen una a la otra, de tal manera que la materia reglamentada por ambas aparece — desde el punto de vista de la interpretación- como no reglamentada, o sea, como si no existiera ninguna de las dos normas. Las dos dejan de ser válidas» (CT 90 y ss.) ${ }^{19}$.

Por comodidad, a partir de ahora, y siguiendo un uso ampliamente implantado entre nosotros, denominaré «antinomias» a esos conflictos (lógicos) entre normas. Son ellas las que representan el desafío más importante a la pretensión de coherencia de un sistema jurídico. Quienes sostienen, como de hecho hizo KELSEN durante casi toda su vida, que el Derecho es un sistema normativo intrínsecamente coherente, suelen pensar precisamente (y sólo) en la ausencia de antinomias. En adelante entenderé por problema de coherencia del Derecho como sistema normativo el problema de si pueden existir antinomias, si el sistema puede contener normas que dirijan la conducta de forma lógicamente incompatible.

\subsection{El concepto de antinomia}

Pero antes de examinar la respuesta de KELSEN a ese problema es conveniente precisar un poco más el concepto de antinomia. Parafraseando la definición antes consignada podemos decir que dos normas constituyen una antinomia, cuando 1) perteneciendo al mismo sistema normativo, 2) refiriéndose al mismo supuesto de hecho y 3) imputan consecuencias jurídicas (lógicamente) incompatibles. De modo que, si tenemos un sistema $\mathrm{S}$ y dos normas $\mathrm{N}_{1}$ y $\mathrm{N}_{2}$, que obedecen a la forma canónica $\mathrm{x} \rightarrow$ ! $\mathrm{y}$ —donde $\mathrm{x}$ es un supuesto de hecho e !y la consecuencia jurídicamente imputada,

18 Tengo que puntualizar que el modo como KELSEN describe lo que él denomina «conflicto teleológico» entre normas hace pensar que lo que él tenía en mente no era tanto un conflicto entre los fines perseguidos por varias normas (incoherencia teleológica en el sentido de ENGISCH) como más bien un conflicto de deberes producido circunstancialmente por la aplicación de dos normas a un caso concreto —esto es, un caso de lo que T. MAZAREsSE denomina paranomia y C. AlCHOURRón «inconsistencia normativa condicional». El ejemplo que él pone - la persona que se ve ante el dilema de obedecer una norma que le prohíbe hollar un lugar sagrado y otra que le obliga a prestar ayuda a alguien en peligro- se ajusta perfectamente a la definición de paranomia (vid. CT 85 y ss; vid. también E. GARCía MÁYNEZ, «Some considerations on the problem of antinomies in the law», ARSP, 49 (1963), y Lógica del raciocinio jurídico, México, FCE, 1964, pp. 117 y ss.).

19 La posición que adopta KELSEN aquí contrasta con la que mantiene en la mayor parte de sus escritos. Según su opinión más reiterada, en caso de antinomia no siempre se anulan las dos normas; como veremos, en algunas ocasiones se anula alguna de ellas, en otras se reinterpretan de modo que se asegure la validez de las dos. Es explicable que en esta ocasión KELSEN procediera con cierto descuido, si se tiene en cuenta que los conflictos entre normas no era el tema del escrito. 
siendo ! un operador deóntico abstracto— ${ }^{20}$, para que podamos hablar de antinomia tienen que darse las tres condiciones siguientes:

1) $\mathrm{N}_{1}, \mathrm{~N}_{2} \in \mathrm{S}$

2) $x_{1}=x_{2}$

3) $! \mathrm{y}_{1} \neq ! \mathrm{y}_{2}$

Unas breves puntualizaciones ayudarán a precisar esas tres condiciones, y de paso a llamar la atención sobre algunas peculiaridades (y también insuficiencias) de la caracterización kelseniana del fenómeno que denominamos «antinomia».

(Ad 1) La primera condición parece obvia. Que una norma de un sistema jurídico castigue la interrupción voluntaria del embarazo mientras la de otro obliga a los médicos del sistema público de salud a practicar abortos en determinadas circunstancias es un caso de normas cuyo contenido es incompatible, pero no representa ningún problema de coherencia para ninguno de los dos sistemas. Los problemas de compatibilidad lógica tienen que ver con la validez simultánea de varias normas, y sólo pueden darse entre normas que tienen el mismo fundamento de validez, es decir, en el interior de un mismo sistema:

«Dado que [...] dos normas que se contradicen, esto es, que ordenan comportamientos opuestos, no pueden ser consideradas simultáneamente como válidas, y dado que sólo normas que tienen el mismo fundamento de validez, y, por lo tanto, constituyen una unidad, un orden normativo, un sistema de normas, no pueden contradecirse, no pueden estar en conflicto, dos ordenamientos normativos que no tienen el mismo fundamento de validez no pueden ser considerados simultáneamente como válidos» [BRO 1406 (105)).

En este punto es crucial la distinción entre antinomia y conflicto de deberes. Dos normas que pertenecen a sistemas normativos diferentes pueden provocar un conflicto de deberes a una persona, si está sujeta a ambos sistemas normativos, sin que, sin embargo, produzcan una antinomia ${ }^{21}$. Ése es el caso de los conflictos entre obligaciones jurídicas y deberes morales. Cuando una norma jurídica entra en colisión con las convicciones morales de una persona, produce en ella un conflicto de deberes. Por más angustioso que pueda ser, ese conflicto no representa ningún problema de coherencia sistemática ni para el Derecho ${ }^{22}$ ni para la moral. En ese caso no estamos ante un conflicto lógico sino más bien ante un conflicto psicológico ${ }^{23}$, en el que no están involucradas relaciones de validez entre normas:

20 !y admite las consabidas interpretaciones de «obligatorio hacer y» (Oy), «prohibido hacer y» $(V y)$ y «permitido hacer y» (Py).

21 Vid. GT 375 (446 y ss.).

22 A menos que uno esté dispuesto a sostener, por ejemplo, la concepción yusnaturalista clásica según la cual las leyes positivas derivan (por vía conclusión o por vía de determinación) de la ley natural (vid. Summa Theologiz, I. ${ }^{\text {a }}$-II. ${ }^{x}$, Q. 95 a. 2.) de modo que la compatibilidad con las normas morales es condición de validez de las normas jurídicas

23 Este «conflicto de deberes», dice KELSEN, es en realidad un proceso «que no se desarrolla en absoluto en la esfera del deber ser, que no es una contradicción entre dos juicios deónticos (Sollurteile), sino que es la concurrencia de dos motivos diferentes, de dos impulsos psíquicos para la acción que van en direcciones diferentes. Una situación que, por consiguiente, permanece enteramente en la esfera del ser. El juicio que constata ese hecho no contiene una contradicción lógica, igual que no la contiene el juicio que constata la incidencia de dos fuerzas contrarias sobre un cuerpo» [PG 303; NPR 75; en términos sustancialmente idénticos GT 375 (447)]. 
«... el jurista, es decir, aquel que considera al Derecho como un sistema de normas válidas, tiene que prescindir de la moral como un sistema de normas válidas, y el moralista, esto es, aquel que considera la moral [...] como un sistema de normas válidas, tiene que prescindir del Derecho como sistema de normas válidas. [...] No existe ningún punto de vista desde el cual la moral y el Derecho pueden ser considerados simultáneamente como órdenes normativos válidos» [BRO 1406 (106); en términos parecidos PG 304].

Así, pues, no todo conflicto de deberes, obedece a una antinomia: un conflicto de deberes puede producirse a partir de normas que proceden de sistemas diferentes, mientras que la antinomia no ${ }^{24}$. Entre normas que pertenecen a sistemas diferentes sólo pueden producirse antinomias cuando por el procedimiento del reenvío o de la recepción uno de ellos (o ambos) haya aceptado la validez de normas producidas por el otro; en ese caso, para expresarlo con la terminología de KELSEN, se ha producido entre los dos sistemas una «delegación» de poder normativo que ha creado entre ellos relaciones de coordinación o de subordinación, mediante las cuales se produce una apropiación total o parcial del contenido normativo de otro sistema.

Como indicaré brevemente más adelante, a partir de aquí KELSEN da un paso más, interpretando esa relación entre sistemas en términos de una integración en un único sistema. Si aceptamos que sólo pueden afirmarse como simultáneamente válidas normas que pertenecen a un solo y el mismo sistema ${ }^{25}$, la relación de delegación (unívoca o biunívoca) establecida entre dos sistemas (por medio de mecanismos como el reenvío o la recepción), que permite que normas de un sistema sean consideradas válidas y aplicables al otro, sólo es posible si ambos sistemas se consideran formando parte de un único sistema integrado ${ }^{26}$. En este contexto KELSEN, pensando en los casos de remisión entre sistemas jurídicos y morales y entre sistemas jurídicos nacionales, formuló la tesis de que la unidad del sistema equivale a su unicidad — que un sistema existe, como conjunto de normas válidas, a condición de que sea único, de modo que todas las normas válidas formen parte del mismo y único sistema-, y muy pronto construyó sobre esa tesis su doctrina sobre la unidad del Derecho internacional y el Derecho interno. Aunque la tesis de la unicidad del sistema me parece muy problemática, no entraré ahora a discutirla, porque no es necesaria para fijar el concepto de antinomia ${ }^{27}$.

$(A d 2)$ Para que exista antinomia las normas implicadas tienen que regular el mismo supuesto de hecho. El supuesto de hecho de una norma tiene cuatro componentes:

24 Es conveniente distinguir dos casos diferentes de conflictos de deberes que no son antinomias. Por una parte, tenemos el caso de las paranomias (T. MAZZARESE), que se da entre dos normas del mismo sistema jurídico que son lógicamente compatibles pero que, en conjunción con las circunstancias particulares del caso, producen un conflicto de deberes (vid. supra n. 12). Por otra, tenemos el caso de las obligaciones conflictivas a las que puede encontrarse uno sujeto por el hecho de estar sometido a sistemas normativos diferentes.

25 «Si existen dos sistemas normativos distintos, entonces desde el punto de vista de un conocimiento orientado a la validez de las normas sólo uno de esos dos sistemas puede ser aceptado como válido, y no los dos simultáneamente» (PG 301, NPR 73 y ss.).

${ }_{26}$ En los casos en los que «el Derecho positivo remite expresamente a normas morales y la moral a reglas jurídicas positivas, o el Derecho alemán dispone la aplicación del Derecho francés, y el Derecho francés la del alemán», afirma KELSEN, se produce una relación de «delegación» entre los sistemas implicados. «El ordenamiento delegado y el delegante [...] se encuentran en relación de supra-subordinación. Pero semejante relación de subordinación presupone la unidad del sistema, y sólo es posible dentro de uno y el mismo orden total que abarca tanto el orden superior como el inferior» (PG 304, NPR 76).

27 En 2.0 infra haré una breve referencia, casi puramente alusiva al nudo de problemas aquí implicado. 
i) los destinatarios de la norma; ii) el lapso temporal dentro del cual la norma es aplicable; iii) el marco espacial de aplicación de la norma, y iv) la conducta regulada por ella. Se da antinomia cuando dos normas se dirigen a los mismos sujetos en las mismas circunstancias temporales y espaciales, contemplando la misma conducta, y sin embargo regulándola de forma diferente.

Podemos expresar esta condición de un modo algo diferente. Adoptando una terminología kelseniana muy conocida, podemos decir que las normas tienen cuatro ámbitos de validez (Geltungsbereiche) ${ }^{28}$ : i) el ámbito de validez personal (P) lo constituyen los sujetos a los que la norma se aplica; ii) el ámbito de validez temporal (T) está constituido por el lapso de tiempo dentro del cual la norma es aplicable; iii) el ámbito de validez territorial o espacial (E) lo constituye el espacio dentro del cual esa norma es aplicable, y iv) el ámbito de validez material (M) lo constituye la conducta objeto de regulación. El universo de los casos que caen dentro del supuesto de hecho de una norma está formado por la intersección de esos cuatro ámbitos de validez: $\mathrm{x}=(\mathrm{P} \cap$ $\mathrm{T} \cap \mathrm{E} \cap \mathrm{M})$. Pues bien, antinomia sólo puede existir entre normas que comparten, en todo o en parte, el supuesto de hecho en todos y cada uno de esos cuatro ámbitos de validez. Podríamos, pues, reformular la segunda condición en los siguientes términos:

\section{2') $\quad(\mathrm{P} \cap \mathrm{T} \cap \mathrm{E} \cap \mathrm{M})_{1}=(\mathrm{P} \cap \mathrm{T} \cap \mathrm{E} \cap \mathrm{M})_{2}$}

Pero esta formulación es todavía incompleta. Para que exista antinomia tiene que haber coincidencia en todos y cada uno de los ámbitos de validez de las dos normas, pero esa coincidencia puede afectar sólo parcialmente al contenido del supuesto de hecho de una de las normas afectadas, o de las dos. Siguiendo la conocida clasificación de antinomias propuesta por A. Ross ${ }^{29}$, pueden darse tres casos:

a) Que se dé coincidencia completa entre el supuesto de hecho de una norma y el supuesto de hecho de otra, de modo que no sea posible en ningún caso aplicar una de ellas sin entrar en colisión con la otra. En este caso (en la terminología de Ross, antinomia total-total) podemos hablar de identidad entre ambos supuestos de hecho.

b) Que el supuesto de hecho de una de las normas sea (al menos en alguno de sus componentes) más amplio que el de la otra, de modo que no todos los casos de aplicación de la primera suponen conflicto con la segunda, mientras que todos los casos de aplicación de la segunda entran en conflicto con la primera. En este caso (antinomia total-parcial) existe una relación de inclusión entre el supuesto de hecho de una norma y el de la otra.

c) Que el supuesto de cada una de las normas en parte coincida y en parte no coincida con el de la otra, de modo que la aplicación de cada una de ellas en unos casos entra en conflicto con la otra y en otros no. En este caso (antinomia parcial-parcial) existe una relación de intersección entre los supuestos de hecho de las dos normas ${ }^{30}$.

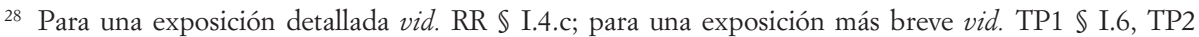
\$ I.3.a, CT 53 y ss., GT \$ I.I.C.h.

${ }_{29}$ Sobre el Derecho y la justicia, trad. de G. R. CARRIÓ, Buenos Aires, Eudeba, 1977, pp. 124 y ss.

30 Un examen de los ejemplos de «conflictos de normas» ofrecidos por KELSEN en ATN cap. 29 I) y D 349 y ss., indica que él no parecía contemplar los casos de antinomia parcial-parcial. Sospecho que en ello no había ninguna razón teórica de fondo, sino probablemente sólo inadvertencia. 
Así, pues, tomando el supuesto de hecho de una norma como el conjunto de los casos a los que esa norma puede aplicarse, y utilizando los símbolos convencionales del álgebra de conjuntos, tendríamos los tres casos siguientes de antinomia:

$\begin{array}{ll}\text { a) } & x_{1} \equiv x_{2} \\ \text { b) } & x_{1} \supset x_{2} \\ \text { c) } & x_{1} \cap x_{2}\end{array}$

(Ad3) La tercera condición requiere algunas puntualizaciones. Ante todo, tal como la he expresado más arriba $\left(! \mathrm{y}_{1} \neq ! \mathrm{y}_{2}\right)$ resulta confusa, porque podría inducir a pensar que se produce antinomia simplemente cuando a propósito del mismo supuesto de hecho dos normas establecen consecuencias jurídicas diferentes. Pero esto es obviamente erróneo. Dos normas pueden prescribir para el mismo supuesto de hecho de forma diferente sin que exista ningún tipo de inconsistencia ${ }^{31}$. En la formulación de esta tercera condición $\neq$ ha de verse como un símbolo que indica no mera diferencia sino incompatibilidad lógica ${ }^{32}$. Así, pues, la tercera condición para que exista antinomia es que las dos normas imputen al mismo supuesto de hecho consecuencias jurídicas que son incompatibles desde el punto de vista lógico.

Ahora bien, a la hora de precisar los casos en que se produce incompatibilidad lógica, la definición kelseniana se revela indebidamente restrictiva. A lo largo de su dilatada trayectoria intelectual KELSEN se ha atenido a una definición de antinomia substancialmente invariable:

«Nos hallamos en presencia de un conflicto lógico (entre normas) cuando una norma estatuye el contenido $a$ y otra norma del mismo sistema estatuye el contenido no $a$; por ejemplo, no debes matar nunca y debes en caso de guerra matar a los enemigos» (CT 85). «Existe un conflicto de normas cuando una norma establece como debida una conducta, mientras la otra establece como debida la omisión de esa conducta» (ATN 168; en términos parecidos GN 870 y ss.).

Con toda consecuencia KELSEN agrega que en esas condiciones no es posible actuar con arreglo al sistema — cualquiera que sea lo que se haga se viola una norma del sistema:

«La situación creada en un conflicto de normas consiste en que si se sigue una de las dos normas en conflicto, se viola la otra...» (ATN 168; en términos parecidos GN 870 y ss.).

Esta definición está recortada a la medida de las normas prescriptivas (esto es, de las normas preceptivas y prohibitivas), y por eso me parece doblemente restrictiva: i) pasa por alto los conflictos lógicos que pueden producirse entre normas prescriptivas y normas permisivas, y ii) ignora la posibilidad de antinomias no deónticas, en particular, las que pueden darse entre normas que confieren potestades.

31 En realidad ése es un caso frecuente. El art. 120.3 de la Constitución («Las sentencias serán siempre motivadas y se pronunciarán en audiencia pública») contiene dos normas a propósito del acto de dictar sentencia: una impone el deber de motivación, la otra impone el deber de publicidad. Pero es obvio que no existe ninguna incompatibilidad entre esos dos deberes.

32 Por lo demás, como se verá inmediatamente, lo que es «diferente» en esa formulación no es propiamente la materia de la prescripción (y) sino más bien la modalidad de la prescripción (la interpretación del operador deóntico !). 
i) La concepción kelseniana de conflicto entre normas, tal como se presenta en la definición, se ajusta a la idea de lo que HART denominó imposibility of joint obedien$\mathrm{ce}^{33}$ : existe conflicto lógico entre dos normas cuando no es posible cumplir las dos al mismo tiempo porque el cumplimiento de una implica la violación de la otra. Como he dicho, ésta es una visión demasiado restrictiva: da cuenta de los conflictos que se producen entre normas que cualifican la misma conducta de forma contraria («Obligatorio $y » /\langle$ Prohibido $y \gg)$, pero ignora los conflictos que pueden darse entre normas que cualifican la misma conducta de forma contradictoria («Obligatorio y»/«Permitido y», «Prohibido $y » / \ll$ Permitido no $y »)^{34}$.

Hay desde luego una importante diferencia entre ambos casos. En un conflicto por contrariedad, es decir, un conflicto en el que están involucradas dos normas prescriptivas («Prohibido conducir por la izquierda»/«Obligatorio conducir por la izquierda»), la antinomia representa un conflicto inesquivable para el destinatario de las normas: como señala KELSEN, haga lo que haga, actuará contra el Derecho, porque no es posible cumplir una norma sin violar la otra. En cambio, en los casos de conflicto por contradicción, en los que está involucrada una norma prescriptiva y otra permisiva («Prohibido fumar»/«Permitido fumar»), el destinatario puede esquivar el conflicto y actuar de conformidad con las dos normas: dado que las normas permisivas no prescriben una acción, el destinatario de dos normas contradictorias queda en libertad de no hacer uso del permiso que le concede una de ellas y cumplir la norma prescriptiva; si cumple la norma prescriptiva («Prohibido fumar»), no viola la permisiva («Permitido fumar») —en realidad una norma permisiva no puede ser violada—. Sin embargo, ello no elimina, creo yo, la incompatibilidad lógica: el hecho de que uno no haga uso del permiso de fumar que le concede una norma, no evita que esa norma esté en conflicto con otra que le prohíbe fumar — porque, efectivamente, si hace uso del permiso concedido por una norma del sistema, viola otra-. Una prohibición o una obligación son contradictorias con un permiso «cuando el uso de la permisión hace lógicamente imposible el cumplimiento de la prohibición (obligación), y viceversa» ${ }^{35}$.

En esa línea HART propone sustituir el test de la imposibility of joint obedience, implícito en la definición kelseniana, por un test de imposibility of joint conformity.

«Es claro que puede haber conflictos entre normas que prohíben y normas o sistemas jurídicos que expresa o tácitamente permiten. Para dar cabida a esos casos tendríamos que hacer uso no sólo de la noción de obediencia, que es apropiada para reglas que mandan o

33 Vid. la segunda parte de «Kelsen's doctrine of the unity of law», ahora en Essays in Jurisprudence and Philosophy, Oxford, Clarendon, 1983.

${ }^{34}$ No deja de ser sorprendente que KeLSEN hable de contradicción entre normas cuando en realidad se refiere a casos de contrariedad. «El principio de contradicción — dice KELSEN— rige [...] tanto para la esfera del ser como para la del deber ser; pues los dos juicios "debe ser a" y "debe ser no a" son tan incompatibles como los dos juicios "es a" y "no es a"» (PG 295 y ss.). Como se ve, KELSEN está contemplando aquí la incompatibilidad entre un enunciado prescriptivo y la negación interna del mismo. Pero, utilizando la terminología tradicional en la lógica deóntica, éste es un caso de incompatiblidad por contrariedad, no por contradicción, que se produce entre un enunciado prescriptivo y su negación externa. HART ha llamado la atención sobre esta imprecisión terminológica: «Si "A debe ser" y "A debe no ser" son lógicamente inconsistentes, no son, como dice KELSEN, contradictorios sino contrarios. El contradictorio de "A no debe hacerse" es "no es el caso que A deba hacerse", y dos enunciados deónticos (ought-statements) con esa forma no describirían dos reglas que mandan y prohíben la misma acción, sino dos reglas una de las cuales prohíbe mientras la otra permite la misma acción» («Kelsen's doctrine...», pp. 330 y ss.).

35 Vid. C. Alchourrón y E. Bulygin, Análisis lógico y Derecho, op. cit., p. 407. 
prohíben alguna acción, sino también de la noción de actuar en base a un permiso o disponiendo de él. Podríamos adoptar el término genérico «conformidad» para comprender tanto la obediencia a las reglas que mandan o prohíben, como actuar en base a un permiso o disponiendo de él [...] Así, si una regla prohíbe y otra regla permite la misma acción por la misma persona al mismo tiempo, la conformidad simultánea será lógicamente imposible y las dos reglas entrarán en conflicto» ${ }^{36}$.

En suma, existe incompatilibidad lógica entre dos normas cuando la conducta está cualificada deónticamente de forma contraria o contradictoria. Si nos atenemos a la lógica de las modalidades deónticas fundamentales, esto ocurre en tres casos:

a) Cuando una norma manda hacer algo y otra probíbe hacerlo; esto es, cuando en el mismo sistema normativo:

$$
\text { Oy } \wedge \text { Vy, en otros términos: } \quad \mathrm{Oy} \wedge \mathrm{O} \neg \mathrm{y}
$$

b) Cuando una norma manda hacer algo y otra permite no bacerlo; esto es, cuando en el mismo sistema normativo:

$$
\text { Oy } \wedge \text { Py, en otros términos: } \mathrm{Oy} \wedge[(\neg \mathrm{Oy}) \vee(\neg \mathrm{O} \neg \mathrm{y})]
$$

c) Cuando una norma probíbe hacer algo y otra permite bacerlo; es decir, cuando en el mismo sistema normativo:

$$
\text { Vy } \wedge \text { Py, en otros términos: } \quad \mathrm{O} \neg \mathrm{y} \wedge[(\neg \mathrm{Oy}) \vee(\neg \mathrm{O} \neg \mathrm{y})]
$$

El primer caso a) es un supuesto de contrariedad entre normas; los dos últimos casos, b) y c), son supuestos de contradicción ${ }^{37}$.

ii) HART parece dar por supuesto que KELSEN no tendría dificultades para aceptar la existencia de conflictos lógicos entre normas prescriptivas y normas permisivas. Si así fuera, el carácter indebidamente restrictivo de su definición podría atribuirse, en este punto, simplemente a inadvertencia. No estoy seguro de ello. Es verdad que KELSEN admite la posibilidad de normas jurídicas permisivas ${ }^{38}$. Pero de eso no se deduce, como parece pensar HART, que estaría dispuesto a revisar en este punto su definición de conflicto entre normas, como si obedeciera a un mero descuido. Un indicio de que no es así lo proporciona el hecho de que en ninguno de los ejemplos de conflictos entre normas que KELSEN presenta aquí y allá ${ }^{39}$ aparezca implicada una norma permisiva. Si consideramos que algunos de esos ejemplos tienen una formulación un tanto alambica$\mathrm{da}$, y que la mayor parte de los casos de antinomia que de forma natural nos vienen a la mente suelen involucrar conflictos entre normas permisivas y normas prescriptivas ${ }^{40}$, el catálogo de ejemplos de antinomia elaborado por KELSEN parece delatar una resis-

36 «elsen's doctrine...», pp. 326 y ss.

37 Como es sabido, que se trate de contrariedad o de contradicción tiene una interesante consecuencia en la forma como puede resolverse la antinomia. Cuando la antinomia se produce entre dos normas contradictorias — casos b) y c) —, podemos resolverla anulando una de las dos normas, pero no las dos, pues en el marco de un sistema normativo una conducta o está prohibida o está permitida, o es obligatoria o está permitida; pero si se da entre dos normas contrarias — caso $a$ ) — , cabe resolver la antinomia anulando una de las dos normas o las dos, porque una conducta puede no estar ni prohibida ni obligada, sino simplemente permitida.

38 Vid. RR 15 y ss. [28 y ss.]

39 Vid. nuevamente el catálogo que ofrece en D 349 y ss. y ATN cap. 29.

40 A guisa de ejemplo, los casos de antinomia formulados por N. BOBBIO en el cap. 3 de la segunda parte de su Teoría general del Derecho, op. cit., son abrumadoramente casos de antinomia por contradicción. 
tencia a formular la definición de conflicto normativo de modo que encaje en ella de forma natural el conflicto entre normas prescriptivas y permisivas. Esa resistencia probablemente se explica por su insistencia en que las normas permisivas son fragmentos de normas o normas no-independientes ${ }^{41}$. Si esto explica por qué los conflictos entre una norma prescriptiva y otra permisiva quedan fuera de la definición kelseniana de conflicto entre normas, igualmente explicaría, creo yo, que también queden excluidos los conflictos entre normas que confieren potestades ${ }^{42}$.

En efecto, en el caso particular de KELSEN esta segunda exclusión se explicaría sin dificultad considerando su concepción reduccionista de la norma jurídica, que le hace concebir las normas que confieren potestades como fragmentos de las normas que estipulan sanciones. Pero para ser justos hay que decir que, independientemente de las peculiaridades de su teoría de la norma jurídica, en este punto KELSEN se encuentra en abundante compañía. Por regla general las definiciones de antinomia que encontramos en los manuales de teoría del Derecho están cortadas a la medida de las normas prescriptivas (en la terminología de HART, «normas que imponen deberes»). Pero es notorio que en un sistema jurídico hay más ingredientes que normas prescriptivas ${ }^{43}$. En particular, parece obvio que pueden producirse antinomias también entre las que siguiendo a HART se conocen como «normas que confieren potestades». Para que pueda cubrir este caso, la definición que hemos venido ofreciendo necesita una cierta adaptación - entre otras razones porque las normas que confieren potestades no cualifican deónticamente la conducta: la consecuencia jurídica de que se dé lo previsto en el supuesto de hecho de la norma no es una conducta debida (prohibida, obligatoria o permitida) sino la producción de un acto válido.

Una norma que confiere potestades enlaza ciertos efectos institucionales a ciertas acciones realizadas reuniendo ciertas condiciones competenciales (condiciones $\mathrm{C}$ ) y ciertas condiciones procedimentales (condiciones P). Dos normas que confieren potestades son lógicamente incompatibles si establecen de forma diferente las condiciones $\mathrm{C}$ y las condiciones $\mathrm{P}$ necesarias ${ }^{44}$ para realizar válidamente el mismo acto $a$. En este caso con arreglo a una norma si se cumplen los requisitos $\mathrm{C}$ y se realiza una cierta secuencia de acciones en las condiciones P se produce $a$; de acuerdo con la otra no se produce $a$. Como afirmar que se ha producido $a$ y que no se ha producido $a$ es incurrir en contradicción, parece evidente que nos encontramos ante un caso de antinomia ${ }^{45}$.

41 Vid. RR 56 [68].

42 Para un examen de este tema, que incluye también una concepción de «conflicto normativo» más amplia que la noción de «antinomia» que manejo aquí, vid. H. HAMnER HiLL, «A functional taxonomy...», ya citado.

43 En realidad la consideración de las normas que confieren potestades como fragmentos de normas o normas no independientes crea graves dificultades a la hora de intentar de cohonestar la teoría kelseniana de la norma jurídica con la teoría kelseniana del Derecho como sistema normativo. Sobre este punto, vid. M. A. RODILLA, «Dinamismo y coactividad. Sobre una incongruencia en la teoría pura del Derecho», en Doxa, $28,2005$.

44 En una versión anterior había escrito «condiciones necesarias y suficientes». Juan Ruiz Manero ha detectado, con razón, un error en esa fórmula. «En mi opinión — me señala—, tienes toda la razón por lo que se refiere a las condiciones necesarias; pero no lo veo por lo que hace a las condiciones suficientes. De hecho [...] muchas veces [...] se establecen diferentes condiciones suficientes para realizar el mismo acto (por ejemplo, otorgar testamento, que puede hacerse mediante diversos conjuntos de condiciones $\mathrm{P}$, que resultan cada una de ellos suficiente y que dan lugar a las diferentes formas en que puede otorgarse válidamente testamento: abierto, cerrado, ológrafo, etc.)».

45 Hace tiempo que los civilistas han localizado en nuestro Código Civil un ejemplo de antinomia que claramente no es deóntica. El art. 759 establece que: «El heredero o legatario que muera antes de que la condi- 
Podemos adaptar a este caso la definición de antinomia en los siguientes términos. Entre dos normas que confieren potestades se da una antinomia cuando 1) perteneciendo ambas normas al mismo sistema, 2) establecen un conjunto diferente de condiciones necesarias 3) para realizar válidamente el mismo acto. Así, pues, si tenemos un sistema $\mathrm{S}$, dos normas (que confieren potestades) $\mathrm{N}_{1}$ y $\mathrm{N}_{2}$, que obedecen a la forma canónica $\mathrm{CP} \rightarrow \mathrm{a}$ (donde $\mathrm{CP}$ es el conjunto de condiciones necesarias para realizar válidamente $a$ ), para que podamos hablar de antinomia tienen que darse las tres condiciones siguientes:

(1) $\mathrm{N}_{1}, \mathrm{~N}_{2} \in \mathrm{S}$

(2) $\mathrm{CP}_{1} \neq \mathrm{CP}_{2}$

(3) $\mathrm{a}_{1} \equiv \mathrm{a}_{2}$

$\mathrm{Y}$ en este caso $\neq$ puede leerse sin dificultad como «es diferente».

En realidad esta ampliación de los casos en que puede producirse incompatibilidad lógica es todavía insuficiente. En teoría pueden producirse incompatibilidades lógicas también entre disposiciones jurídicas que simplemente no son normas —ni normas que imponen deberes, ni normas que confieren potestades-. Supóngase que por mayoría simple el Parlamento español aprueba una ley que restablece la bandera tricolor. Esa disposición es obviamente incompatible con la disposición de la Constitución que determina cuál es la bandera española. Estamos ante dos disposiciones incompatibles: o los colores de la bandera española son rojo y amarillo, o son rojo, amarillo y morado. No estamos aquí propiamente ante dos normas, es decir, ante dos directivas de conducta diferentes, sino más bien ante dos disposiciones performativas que crean la entidad que denominamos «bandera española». Ahora bien, en un sistema jurídico las disposiciones que no son normas están relacionadas con normas ${ }^{46}$. En este caso el art. 4.1 CE está relacionado, por ejemplo, con el art. $543 \mathrm{CP}$ que castiga los ultrajes a los emblemas de la Nación. La existencia de esas dos disposiciones incompatibles generaría una antinomia, porque llegado el caso un juez podría verse en la tesitura de tener que condenar a una persona y tener que absolverla por el mismo hecho.

\section{LA DOCTRINA DE KELSEN SOBRE LA COHERENCIA EN EL SISTEMA JURÍDICO}

Como ya he avanzado, a propósito del tema de la coherencia en el Derecho el pensamiento de KELSEN ha seguido una interesante trayectoria que vale la pena analizar.

\footnotetext{
ción se cumpla, aunque sobreviva al testador, no transmite derecho alguno a sus herederos»; en cambio el 799 establece que «La condición suspensiva no impide al heredero o legatario adquirir sus respectivos derechos y transmitirlos a sus herederos, aun antes de que se verifique su cumplimiento». En este caso no están en conflicto dos normas prescriptivas, sino más bien dos normas que confieren potestades. Comentando este último artículo F. BONET RAMÓN señala que la contradicción se debe a «una copia descuidada y errónea de los arts. 1.041 del Código francés, 854 del italiano de 1865 y 18.10 del portugués...» (Código Civil Comentado, 2. ${ }^{a}$ ed., Madrid, Aguilar, 1964). El ejemplo es doblemente interesante, porque es además un caso de antinomia en el que no es aplicable ninguna de las tres reglas a las que tradicionalmente se recurre para disolver antinomias.

${ }^{46}$ Como es sabido, KELSEN no diría «están relacionadas con normas», sino más bien «son fragmentos de normas». Si admitiéramos esa doctrina reduccionista, estaríamos ante una forma específica del tipo genérico de antinomia, más que ante una variedad distinta.
} 
1) Del tema KELSEN se ocupó por primera vez, que yo sepa, a finales de los años veinte en «Die philosophischen Grundlagen der Naturrechtslehre und des Rechtspositivismus» (1928), uno de sus primeros opúsculos sobre el Derecho natural y al mismo tiempo uno de los primeros escritos en los que formula su concepción del Derecho como sistema normativo ${ }^{47}$. En realidad KELSEN se sirve aquí del concepto de sistema para establecer una diferenciación estructural entre el Derecho natural y el positivo, sobre la que construirá luego buena parte de su crítica a la idea de Derecho natural: el Derecho natural es un sistema normativo estático, mientras que el Derecho positivo es dinámico ${ }^{48}$; desde el punto de vista lógico no pueden coexistir, y los intentos de las doctrinas yusnaturalistas de coordinarlos conducen necesariamente a una desnaturalización de la idea de Derecho natural ${ }^{49}$. Ahora bien, en ese marco de discusión KELSEN introduce inopinadamente la coherencia como una propiedad de los sistemas jurídicos. El Derecho es un sistema normativo inherentemente coherente: la ausencia de antinomias no es simplemente una propiedad deseable del sistema sino una propiedad necesaria. En realidad KELSEN parece pensar que la idea de ausencia de incompatibilidades lógicas está analíticamente implícita en la idea misma de unidad sistemática. En suma, como sistema normativo, el Derecho es una unidad dinámica y también una unidad lógica. En estas condiciones las antinomias no constituyen propiamente una deficiencia que pueda aquejar al sistema jurídico, aunque, como veremos, sí afectan al proceso de interpretación del material proporcionado por los órganos de producción jurídica: las leyes (quiero decir, los textos legales) pueden contener incoherencias, el sistema jurídico, en cambio, no.

2) KELSEN mantuvo esa posición prácticamente intacta hasta bien entrada la década de los cincuenta. Aunque aquí y allá había venido alterando algunas piezas de su teoría del Derecho, la concepción inicial sobre la coherencia del sistema jurídico reaparece sin modificaciones substanciales en la primera edición de la Reine Rechtslebre (1934) y en la General Theory of Law and State (1945), y en líneas generales todavía incluso en el artículo relativamente tardío sobre «Der Begriff der Rechtsordnung» (1958). Hacia finales de los años cincuenta se observa, sin embargo, un cambio significativo, del que ya hay rastros en ese último trabajo. Un estudio más detenido del papel de la lógica en el campo de las normas — del que tenemos noticia a través del intercambio epistolar que mantuvo con U. KLUG- ${ }^{50}$ le lleva a revisar su tesis inicial sobre la aplicabilidad de los principios lógicos (en particular el principio de contradicción) $)^{51}$ a las normas. Con todo, eso no le conduce de momento a abandonar enteramente su posición primera, sino más bien a realizar un reajuste. La operación de reajuste queda documentada en la segunda edición de la Reine Rechtslebre (1960),

47 Algunas de las ideas fundamentales habían aparecido ya pocos meses antes en NPR.

48 «Toda la contraposición entre Derecho natural y Derecho positivo puede en cierto sentido representarse como contraposición entre un sistema normativo estático y otro dinámico» (GP 293).

49 Vid. J. A. Sendín Mateos, «La crítica de Hans Kelsen a la doctrina del Derecho natural», en Revista de Investigaciones Jurídicas (México), 29 (2005), espec. pp. 482 y ss. 1988.

${ }^{50}$ H. Kelsen y U. Klug, Normas jurídicas y análisis lógico, trad. de J. C. Gardella, Madrid, CEC,

51 A propósito de esta expresión se aprecia en KELSEN una cierta vacilación terminológica: en unas ocasiones utiliza Satz von Widerspruch (o Widerspruchsatz) y principle of contradiction en otras habla, en cambio, de Satz von ausgeschlossenen Widerspruch y principle of non-contradiction. En todo caso, utiliza ambas como expresiones intercambiables. Para unificar terminología y simplificar, las he traducido como «principio de contradicción». 
donde una interesante maniobra le permite establecer temporalmente un compromiso entre la exigencia de pensar el sistema jurídico como una unidad lógica y su más reciente convicción de que la lógica no es aplicable a las relaciones entre normas: aunque el principio de contradicción no afecta a la validez de las normas, es una exigencia del pensamiento jurídico describir el Derecho como un sistema libre de contradicciones, y en ese sentido la exigencia de coherencia es aplicable indirectamente al Derecho. En tanto que objeto de conocimiento el Derecho es un sistema normativo coherente.

3) Hasta qué punto ese compromiso era frágil y problemático — basado en realidad en un malentendido-, lo reveló el hecho de que apenas dos años después de la publicación de la segunda edición de la Reine Rechtslebre, en un escrito, breve pero de gran impacto, con el título Derogation (1962) lo rompe de forma inequívoca, abandonando, ahora ya resueltamente, la tesis inicial sobre la coherencia intrínseca del sistema jurídico. De esa tesis ya no queda resto alguno en Recht und Logik (1965) ni en la Allgemeine Theorie der Normen, publicada póstumamente en 1979, seis años después de la muerte del autor. En la que resulta ser su posición definitiva el Derecho se concibe ahora, desde luego, como un sistema normativo dinámico, pero ya no como una unidad lógica: aunque la ausencia de antinomias es una situación deseable, todo sistema normativo dinámico es susceptible de verse aquejado por ellas, y la ciencia jurídica no puede hacer al respecto otra cosa que constatar su existencia.

Podemos, pues, resumir por anticipado la trayectoria kelseniana en los siguientes términos: en la posición inicial la coherencia se presenta como una propiedad necesaria del Derecho como sistema normativo; en la fase de transición el Derecho puede no ser coherente pero ha de ser descrito como coherente; finalmente, de acuerdo con la posición definitiva la coherencia no forma parte de las propiedades necesarias del sistema jurídico ni tampoco de las condiciones necesarias de una descripción científica del Derecho positivo ${ }^{52}$. Como veremos, el cambio doctrinal de KELSEN en este punto afecta no sólo al concepto mismo de sistema jurídico, sino también a la noción de validez de las normas y a la relación entre el Derecho y la ciencia jurídica.

\subsection{La unidad del Derecho como sistema}

Una de las ideas centrales de la teoría pura del Derecho es que el concepto de Derecho está cifrado en términos de un sistema de normas, y por cierto de un sistema dinámico. Que el Derecho sea un sistema de normas significa que es posible reducir a unidad la multiplicidad de las normas que lo integran; que sea un sistema dinámico significa que las normas que lo integran son el producto de actos de voluntad, y que en este sentido son normas positivas. No cualquier agregado de normas constituye un sis-

52 Con frecuencia los comentaristas de KELSEN tienden a distinguir dos posiciones en este tema: la formulada en la segunda edición de la Reine Rechtslebre y la defendida a partir de Derogation. Un examen detallado revela que la trayectoria es algo más compleja. Por regla general se pasa por alto la posición inicial, que KELSEN mantuvo durante más de treinta años, antes de 1960. Una vez que se toma en consideración esa posición inicial, se advierte claramente que la defendida en la segunda edición de la Reine Rechtslebre en realidad representa sólo una fase de transición hacia la posición final. En su artículo de 1977, J. DELGADo PinTo había indicado con toda la claridad deseable la trayectoria seguida por KELSEN en este punto (vid. «El voluntarismo de Hans Kelsen...», op. cit.). 
tema, ni cualquier relación entre normas es relevante como relación sistemática. Para KELSEN la relación entre las normas que es relevante a los efectos de su integración en un sistema es la relación de validación: las normas de un sistema están relacionadas entre sí mediante relaciones de validación, y varias normas forman un sistema si tienen una fuente común de validez. En el caso de los sistemas dinámicos, un conjunto de normas integra el tipo de unidad que denominamos «sistema» en la medida en que todas ellas hayan sido creadas por autoridades normativas cuyo poder de producción de normas deriva de alguna norma (válida) del sistema, y en último término de una única norma suprema, que es la fuente última de validez de todas las normas y a la que KELSEN denomina «norma fundamental» (Grundnorm, basic norm). A diferencia de lo que ocurre en los sistemas estáticos, entre la norma fundamental de un sistema dinámico y el resto de las normas del sistema no hay una relación de contenido: la norma fundamental no determina el contenido del resto de las normas sino sólo el modo como pueden ser creadas. Al fundamentar la validez de una primera norma positiva, la norma fundamental dota de autoridad a un primer poder normativo, el cual, por su parte, puede delegar la potestad de crear normas en otros poderes inferiores. De este modo la norma fundamental pone en marcha un proceso de producción normativa. La unidad sistemática de las normas producidas de ese modo no depende de su contenido, sino sólo de la forma como fueron producidas ${ }^{53}$ : «la unidad de un sistema dinámico es la unidad de una cadena de delegaciones de autoridad (Delegationszusammenhang)» (NPR 73).

Para completar este sumarísimo recordatorio de ideas bien conocidas, es preciso agregar que la norma fundamental que unifica un sistema de normas positivas no puede ser ella misma positiva. Positiva es una norma creada mediante actos de voluntad. Ahora bien, una vez que se acepta el presupuesto de la inderivabilidad del «deber ser» a partir del «ser», resulta claro que los actos de voluntad sólo pueden ser actos creadores de normas si se basan a su vez en alguna norma. Por eso el fundamento del primer acto de voluntad creador de normas - y por tanto el fundamento de un sistema de normas positivas - no puede encontrarse en una norma positiva. La norma fundamental no es, pues, una norma puesta (gesetzt), sino supuesta (vorausgesetzt), no es producto de un acto de voluntad sino más bien del entendimiento ${ }^{54}$ : es una norma cuya validez tenemos que dar por supuesta para poder interpretar un conjunto de hechos $(v . g r$. ciertas declaraciones de voluntad, ciertas decisiones y ciertos actos de poder) como fenómenos creadores de normas, y un conjunto de prescripciones como normas.

«La norma fundamental es así la hipótesis necesaria de todo estudio positivista del Derecho. Al no haber sido creada según un procedimiento jurídico, no es una norma del Derecho positivo; dicha norma no es «puesta» sino «supuesta». Es la hipótesis que permite

53 «Las normas del Derecho [...] no valen en virtud de su contenido. Cualquier cosa puede ser Derecho [...] Una norma vale como norma jurídica sólo porque fue dictada de una forma bien determinada, porque fue producida de acuerdo con una regla bien determinada, porque fue establecida según un método específico» (TP1 96; en términos parecidos TP2 136 y ss.).

${ }^{54}$ Es sabido, KELSEN, queriendo ser enteramente coherente con su tesis de que las normas son el sentido de actos de voluntad, terminó afirmando que también la norma fundamental es el sentido de un acto de voluntad, sólo que en este caso no pudiendo ser el resultado de un acto de voluntad real había que entenderla como fruto del acto de voluntad ficticio de una autoridad ficticia (ATN 206 y ss.). Ahora bien, como quiera que las ficciones sólo existen en el pensamiento, afirmar tal cosa significa admitir que la norma fundamental es un producto intelectual y no volitivo. 
a la ciencia jurídica considerar al Derecho como un sistema de normas válidas. Todas las proposiciones por las cuales esta ciencia describe su objeto están fundadas sobre el supuesto de que la norma fundamental es una norma válida. Pero esto no significa que la ciencia del Derecho afirme la validez de la norma fundamental: se limita a declarar que si la norma fundamental es supuesta válida, el establecimiento de la primera constitución y los actos cumplidos conforme a ella tienen la significación de normas válidas» (TP2 139).

Es interesante señalar que desde sus primeras exploraciones de la idea de Derecho como sistema normativo KELSEN pone en juego una idea de sistema densamente cargada de presupuestos. Para empezar, ve en la unidad sistemática un «postulado epistemólogico» que opera como condición necesaria del conocimiento jurídico. Y a continuación vincula a la idea de unidad (sistemática) tanto la propiedad de la unicidad como la propiedad de la ausencia de contradicciones: sólo podemos conocer el Derecho en tanto que unidad sistemática, y eso a condición de que lo pensemos como el único sistema y además como un sistema coherente. En un escrito relativamente temprano (y dentro de un epígrafe con el significativo título de «el postulado de la unidad del sistema») KELSEN pone en conexión esas ideas formulando una concepción muy fuerte de la unidad sistemática, a la que con escasas variaciones se atiene casi hasta el final de su vida:

«Conocer un objeto y conocerlo como unidad significan lo mismo.

Que la unidad de un sistema de normas significa al mismo tiempo su unicidad, es sólo una consecuencia del principio de unidad — un principio determinante, igual que para todo conocimiento, también para el conocimiento del deber ser, para el conocimiento de las normas-, cuyo criterio negativo es la imposibilidad de la contradicción lógica» (PG 305; NPR 76).

Esta formulación, extraordinariamente apretada, de la idea de unidad sistemática contiene una batería de tesis conectadas en cadena:

1. La tesis de la unidad sistemática como postulado del conocimiento jurídico —en palabras de KELSEN, «la exigencia gnoseológica de considerar todo el Derecho en un sistema, es decir, de considerarlo desde un mismo punto de vista como un todo en sí cerrado» (TP1 178). Si no me equivoco, KELSEN entiende esta tesis como una derivación especial de una convicción teórica más general, de ascendiente kantiano, y muy profundamente arraigada en él, a saber, que el conocimiento científico aspira a aprehender su objeto como unidad - lo que él denomina «la exigencia de unidad de todo conocimiento» (PG 318) ${ }^{55}$ según el cual «conocer un objeto significa conocerlo como unidad» (PG 305, NPR 76): «toda búsqueda del conocimiento científico está motivada por el empeño en encontrar unidad en la aparente multiplicidad de los fenómenos» [GT $374(446)]^{56}$.

55 En la versión inglesa, incorporada como apéndice a GT, se lee: «el postulado de la unidad del conocimiento» (GT 421).

56 No es enteramente claro, en mi opinión, el significado preciso de ese postulado general de la unidad del conocimiento, ni tampoco es inmediatamente evidente que conocer el Derecho como unidad exija concebirlo precisamente como el tipo de unidad que KELSEN denomina «sistema» u «orden». Pero lo cierto es que los efectos de esta idea de fondo se irradian a lo largo de toda la teoría pura del Derecho. Si no interpreto erróneamente, es uno de los motores del empeño de KELSEN por superar los múltiples dualismos que en su opinión han infectado el pensamiento jurídico. Entre los más importantes de los dualismos combatidos por KELSEN están, para empezar, el dualismo metafísico mundo sensible/mundo inteligible que él detecta en el yusnaturalismo, a continuación algunas oposiciones características del aparato conceptual corriente entre los juristas ( $v$.gr. Dere- 
2. La tesis según la cual la unidad del sistema implica unicidad. Con arreglo a ella es «lógicamente imposible» considerar simultáneamente válidas dos normas pertenecientes a sistemas normativos diferentes, lo cual «lleva a la necesidad lógica de concebir todo el Derecho desde uno solo y el mismo punto de vista y a considerarlo como un sistema único» (TP2 204). Como es sabido, esta tesis conduce a KELSEN a interpretar las relaciones de subordinación o de coordinación entre varios sistemas jurídicos, establecidas a través de mecanismos como la recepción y el reenvío, en términos de una integración de los sistemas implicados en un único sistema con una única norma fundamental ${ }^{57}$, y está en la base de su grandiosa — pero extraordinariamente problemática - visión de un mundo jurídicamente unificado.

3. La tesis de que la unidad del sistema implica no sólo ausencia sino incluso «imposibilidad» de contradicción. Esta tercera tesis supone concebir el Derecho como «un sistema lógicamente cerrado» (TP1 120), esto es, como una «unidad lógica» ${ }^{58}$. KELSEN vincula de una forma particularmente estrecha la tesis de la ausencia de contradicciones a la idea de sistema hasta el punto de hacer de ella la expresión misma de la unidad sistemática: «Dado que la norma fundamental es el fundamento de la validez de todas las normas que pertenecen a uno y el mismo orden jurídico, constituye la unidad en la multiplicidad de esas normas. Esa unidad se expresa también en que un orden jurídico puede ser descrito en proposiciones jurídicas que no se contradicen» [RR 209 (214), cursivas mías].

4. La tesis según la cual la ausencia de contradicción es un criterio (negativo) de la unicidad. Esta última tesis conecta las dos anteriores del siguiente modo: si un sistema normativo no admite contradicciones entre normas (T. 3), y es verdad que no es posible afirmar como simultáneamente válidas normas pertenecientes a dos sistemas diferentes, sólo podremos aceptar que dos o más sistemas jurídicos relacionados entre sí a través de relaciones de validez forman en realidad un sólo sistema (T. 2) a condición de que entre ellos no sean posibles contradicciones

Ninguna de esas tesis es inmediatamente obvia; cada una de ellas por separado suscita interrogantes, que se complican cuando se considera su fuerza conjunta. No puedo articular ahora una discusión mínimamente satisfactoria de la fuerte interpretación kelseniana de la idea de unidad del Derecho como sistema. HART recorrió ya un buen trecho ${ }^{59}$ en su agudo análisis de la tesis kelseniana de la unidad del Derecho estatal y el Derecho internacional —una tesis en cuya defensa KELSEN había movilizado de forma particularmente explícita y coordinada las cuatro tesis que acabo de diferenciar ${ }^{60}$. No pudiendo discutirlas ahora todas ellas, me contentaré con aislar la tercera. Voy, pues, a examinar de qué modo KELSEN defendió casi hasta el final de su vida la tesis según la

\footnotetext{
cho subjetivo/deber jurídico, persona física/persona jurídica, creación/aplicación, Derecho público/Derecho privado, Derecho/Estado), finalmente el dualismo Derecho estatal/Derecho internacional.

57 Vid. PG 304 y ss., NPR 76.

58 Creo que en la tesis del Derecho como unidad lógica están conectadas la tesis de la coherencia $y$ la tesis de la compleción. Si, como KELSEN piensa, la existencia de incompatiblidades lógicas arruina la unidad del sistema, con tanta más razón la arruinará la presencia de lagunas, ya que para resolver los casos de lagunas los órganos de aplicación del Derecho tendrían que echar mano de recursos exógenos. Como es sabido, KelSEN defiende las dos tesis. Pero lo cierto es que al formular su idea de la unidad lógica del Derecho no las conecta inmediatamente.

59 En «Kelsen's doctrine of the unity of law», ya citado.

60 Vid. TP1 $\$ 50$; GT 2. ${ }^{a}$ Parte, cap. VI $₫ C$; TP2 cap. XIII $₫ 4 ;$ BRO $₫ 3 ;$ RR $₫ 43$.
} 
cual el Derecho, en tanto que sistema, está necesariamente libre de contradicciones, y las razones por las cuales terminó por abandonarla.

\subsection{La posición inicial}

Hasta un momento relativamente tardío de su trayectoria intelectual KELSEN vinculó a la noción de sistema ciertas propiedades lógicas entre las cuales se encuentra, además de la ausencia de lagunas, precisamente la coherencia en el sentido de ausencia de antinomias. El Derecho no tiene sólo la propiedad formal de la unidad de un sistema continuo de delegación de poderes normativos, sino también la propiedad material de la «unidad lógica» o ausencia de contradicciones: un conjunto de normas lógicamente incompatibles no constituye un sistema, incluso si han sido creadas de forma regular, siguiendo una cadena bien formada de poderes normativos. KeLSEN expresa esa tesis en términos inequívocos, en una formulación sorprendente:

«La unidad de un orden jurídico es la unidad de una continuidad creadora (Erzeugungszusammenbang ${ }^{61}$. Esta unidad se expresa también en el hecho de que un orden jurídico puede ser descrito mediante proposiciones no contradictorias» [BRO 1401 (100), cursivas mías].

Esta formulación, realizada en una fecha (1958) relativamente tardía, es sorprendente porque en ella la segunda frase parece presentarse como una paráfrasis de la primera, como si la idea de «unidad dinámica», entendida como «la unidad de una continuidad creadora», fuera equivalente o implicase la idea de una «unidad lógica», entendida en el sentido de ausencia de contradicción ${ }^{62}$. De la fusión de esas dos ideas resulta la tesis kelseniana temprana de la coherencia intrínseca del sistema jurídico. Pero esa fusión necesita explicación, porque salta a la vista que se trata de dos ideas diferentes, que incluso parecen apuntar a dos visiones enfrentadas del sistema jurídico: por un lado, el sistema jurídico entendido como un conjunto dinámico de normas positivas, resultado de decisiones realizadas en momentos diversos por autoridades diversas, y, por otro, el sistema jurídico entendido como un conjunto coherente de enunciados prescriptivos.

Punto de partida de la temprana tesis kelseniana de la coherencia intrínseca del sistema jurídico es el presupuesto de que entre las normas rigen relaciones lógicas análogas a las que se dan entre enunciados asertóricos o descriptivos. También para ellas rigen, pues, los principios lógicos. En particular, el principio de contradicción es aplicable tanto a los enunciados asertóricos como a las normas. De modo que, así como por razones lógicas el enunciado «es a» y el enunciado «no es a» no pueden formar parte del mismo sistema de enunciados, tampoco es posible que «debe ser a» y «no debe ser a» formen parte del mismo sistema normativo. La aplicación de los principios de la lógica a las relaciones entre enunciados asertóricos tiene que ver con sus condi-

${ }^{61}$ No es fácil verter al castellano la expresión alemana. He adoptado aquí la traducción de M. I. AZARETO, aunque creo que es tentador traducirla por «cadena de producción».

62 Cuando más adelante, en ese mismo artículo, insiste en la «exigencia gnoseológica de concebir a todo Derecho en un sistema, esto es, de concebirlo a partir de uno solo y el mismo punto de vista como un todo que puede describirse sin contradicciones» [BRO 1409 (109), cursivas mías], vuelve KELSEN a presentarnos dos ideas enteramente diferentes como si fueran dos formas diferentes de expresar la misma idea. 
ciones de verdad; su aplicación a las relaciones entre enunciados prescriptivos afecta a las condiciones de validez de los mismos en tanto que normas. Si es la validez lo que determina la existencia de una norma, y el fundamento de la validez lo que determina su pertenencia a un sistema, y admitimos que dos normas contradictorias no pueden ser ambas simultáneamente válidas, entonces ambas no pueden existir como normas pertenecientes al mismo sistema normativo. Si de dos enunciados contradictorios ( $\mathrm{El}$ hierro es un metal»/《El hierro no es un metal») podemos afirmar que necesariamente uno es falso y que ambos no pueden formar parte del mismo sistema de enunciados, de dos normas contradictorias («Está prohibido fumar»/《Está permitido fumar») o contrarias («Está prohibido conducir por la izquierda»/«Es obligatorio conducir por la izquierda») podemos afirmar que una de las dos necesariamente es inválida (tal vez las dos) —ambas no pueden formar parte del mismo sistema normativo, en realidad ambas no pueden propiamente coexistir como normas:

«El principio de contradicción rige [...] tanto para la esfera del ser como para la del deber ser; pues los dos juicios "debe ser a" y "no debe ser a" son tan incompatibles como los dos juicios "es a" y "no es a". Si el material jurídico que se presenta al conocimiento muestra una contradicción de este tipo, que anula todo sentido, si los actos jurídicos aparecen con un sentido subjetivo de ese tipo, esa contradicción, si se trata de normas de uno y el mismo sistema, tiene que encontrar una solución, es decir, el sentido subjetivo contradictorio no puede convertirse en sentido objetivo» (PG 295 y ss.)

En este pasaje es crucial la combinación de dos distinciones: i) la distinción entre el «sentido subjetivo» y el «sentido objetivo» de los actos de voluntad, y ii) la distinción entre las «normas» y el «material jurídico que se presenta al conocimiento». El resultado de esa combinación es que el contenido de los actos de prescripción proporciona el «material» al conocimiento jurídico, pero no constituye inmediatamente las normas del sistema. Y eso le permite a KELSEN concebir al Derecho como un sistema normativo dinámico y al mismo tiempo carente de contradicciones.

i) Es característico de los sistemas dinámicos el que las normas entren en el sistema mediante prescripciones, esto es, mediante actos de voluntad dirigidos a otros en el sentido de que hagan algo. Una prescripción, un mandato, es un acto de voluntad dirigido a la conducta de otro y cuyo sentido subjetivo es que algo debe ser. Pero no de toda prescripción deriva que desde el punto de vista objetivo aquello que se prescribe deba ser: no todo acto de prescripción produce los efectos propios de una norma - en particular, no todo mandato genera una obligación-. Desde el punto de vista externo de un observador el atracador que conmina a su víctima a entregarle una cantidad de dinero no hace nada substancialmente diferente del recaudador de impuestos que exige al contribuyente una cantidad de dinero amenazándole con un castigo: en ambos casos una persona se dirige a otra expresando que algo debe ser y conminándole a hacer algo. Si en el segundo caso el sentido subjetivo del acto coincide con su sentido objetivo - de modo que en ese caso el destinatario del mandato «debe» (e. d. está jurídicamente obligado a) entregar el dinero que se le reclama-, es porque ese acto está respaldado por una norma jurídica que autoriza al recaudador a dirigirse en esos términos al contribuyente ${ }^{63}$. Ahora bien, esa norma es, por su parte, el sentido de un

63 Vid. PG 297 y s.; TP1 28 y ss.; TP2 36 y ss. La distinción entre el sentido subjetivo y el sentido objetivo de los actos de prescripción persiste a lo largo de toda la obra de KELSEN. En un momento relativamente tardío, 
acto de voluntad, que sólo puede ser capaz de producir normas en la medida en que se apoya en otra norma, y así sucesivamente siguiendo una «cadena de validez» (J. RAz) cuyo primer eslabón es una primera norma positiva, a la que podemos denominar «constitución», a cuya validez provee la norma fundamental del sistema. Todo esto lo conocemos ya. Lo que ahora añade KELSEN es que si el sentido subjetivo de diversos actos jurídicos es contradictorio, esos actos no pueden ser creadores de normas válidas del mismo sistema: «el sentido subjetivo contradictorio no puede convertirse en sentido objetivo». El punto es crucial porque significa que la coherencia, y no sólo la creación regular por un órgano competente autorizado por el sistema, forma parte de las condiciones de validez de las normas jurídicas — que las relaciones entre normas están sujetas a principios lógicos a los efectos de sus validez-. Pero para aclarar su significación necesitamos introducir la segunda distinción.

ii) En el pasaje antes acotado KELSEN distingue entre «el material jurídico que se presenta al conocimiento» y las normas mismas. El material jurídico procede de actos de voluntad y está dado al conocimiento; las normas, en cambio, son más bien construidas por el conocimiento en el curso de un proceso de interpretación orientado jurídicamente:

«El sentido que tiene el material suministrado en el proceso de creación jurídica sólo adviene por medio de una interpretación apoyada en último término en la norma fundamental. Y este sentido — que es un sentido objetivo creado por el conocimiento jurídico- puede diferir enteramente del sentido subjetivo afirmado por los actos a interpretar» (PG 298).

Podemos expresar esta distinción en términos de la distinción entre disposiciones jurídicas y normas jurídicas ${ }^{64}$. Las disposiciones jurídicas son los enunciados contenidos en los textos jurídicos, producto de decisiones normativas realizadas por los órganos autorizados al efecto por el sistema. Las normas jurídicas, en cambio, son el contenido de sentido normativo de esas mismas disposiciones, y son resultado de procesos de interpretación. Las disposiciones jurídicas integran los textos jurídicos (las «leyes»), pero no inmediatamente el sistema jurídico: el sistema jurídico está integrado por normas, no por disposiciones. Como acabamos de ver, KELSEN tiene buen cuidado en advertir que no necesariamente existe una correspondencia estricta entre el sentido subjetivo de los actos creadores de Derecho y su sentido objetivo, es decir, entre las disposiciones jurídicas y las normas contenidas en un texto jurídico. Y en este punto distingue dos casos enteramente diferentes ${ }^{65}$. En primer lugar, dado que para él sólo son normas jurídicas (completas) aquellas que enlazan con el nexo deóntico un acto de coacción (como consecuencia) a un supuesto de hecho (como condición), una mera prescripción, incluso si ha sido establecida por un órgano autorizado por el sistema, no puede ser considerada inmediatamente como norma jurídica: o es un fragmento de

cuando ha pasado a abrazar una concepción imperativista de las normas, KELSEN se atiene todavía a ella: «El sentido subjetivo de todo acto imperativo (Befeblsakt) es un deber ser; también lo es el acto del salteador de caminos que ordena a alguien entregarle su dinero. Pero sólo cuando el acto está autorizado por una norma que se presupone válida el sentido subjetivo de un acto imperativo es también su sentido objetivo, y eso quiere decir que es una norma vinculante» [RL 1489 (29)].

${ }_{64}$ Para esta distinción, vid. el iluminador tratamiento de R. GuAstini, Dalle fonti alle norme, Torino, Giappichelli, 1990 (cap. 1), y Distinguiendo, trad. de J. Ferrer i Beltrán, Barcelona, Paidós, 1993 (cap. 2 de la segunda parte).

${ }_{65}$ PG 297 y ss. 
alguna norma jurídica que debe ser integrada enlazándole algún acto coactivo, o, si esto no es posible, es una simple declaración de intenciones o una mera expresión de deseos del legislador ${ }^{66}$. En segundo lugar, y más interesante para nosotros, el contenido significativo de dos disposiciones jurídicas que prescriben de forma lógicamente incompatible no puede transformarse inmediatamente en dos normas (válidas).

Una vez establecido esto, para completar la tesis de KELSEN sobre la coherencia del sistema jurídico basta agregar la analogía que, como ya he dicho, establece él entre la pretensión de verdad de los enunciados asertóricos y la pretensión de validez de las normas: así como por razones lógicas dos enunciados asertóricos contradictorios no pueden ser ambos verdaderos, por las mismas razones dos enunciados normativos contradictorios no pueden ser ambos válidos; y como la validez es la forma de existencia de las normas, al menos uno de esos dos enunciados no es el contenido de una norma, ambos no pueden coexistir en el mismo sistema normativo. En este sentido el sistema jurídico es una unidad lógica: el Derecho está libre de antinomias incluso si el legislador produce disposiciones jurídicas contradictorias.

Esto no significa negar la existencia de ese fenómeno que denominamos «antinomia». Significa, más bien, situarlo en el lugar apropiado. Antinomias pueden producirse entre disposiciones jurídicas —en el nivel del «discurso de las fuentes» (GUASTINI) - , pero no entre normas — en el nivel del sistema jurídico como conjunto de normas (válidas). Una vez más la analogía entre enunciados asertóricos y enunciados normativos es pertinente: del mismo modo que, como cuestión de hecho, en un mismo documento pueden encontrarse dos enunciados asertóricos contradictorios, también en un mismo texto legal pueden darse dos enunciados normativos (disposiciones jurídicas) contradictorios; pero igual que la presencia en un documento no decide sobre la pretensión de verdad de los enunciados asertóricos, tampoco la presencia en un texto jurídico decide sobre la pretensión de validez de los enunciados normativos. Ahora bien, entre enunciados asertóricos la función de verdad es la relación relevante a los efectos de la integración en un sistema de enunciados; entre normas la relevante es la relación de validación. Por eso, si dos disposiciones contradictorias no pueden ser ambas simultáneamente válidas, entonces ambas no pueden «transformarse» en normas jurídicas. La transformación de disposiciones incompatibles en normas se produce en el curso de un proceso de interpretación que está sujeto a reglas lógicas. En el curso de ese proceso se disuelve la incompatibilidad y se transforma el «material» proporcionado por las fuentes del Derecho en sistema jurídico:

«Dos normas que por su significado se contradicen y por consiguiente se excluyen lógicamente la una a la otra no pueden considerarse simultáneamente válidas. Una de las principales tareas del jurista es ofrecer una presentación consistente del material con el que trata. Puesto que el material se presenta en expresiones lingüísticas, a priori es posible que contenga contradicciones. La función específica de la interpretación jurídica es eliminar esas contradicciones, mostrando que son falsas contradicciones (sham contradictions). Es mediante la interpretación jurídica como el material jurídico se transforma en un sistema jurídico» [GT 375 (446), cursivas mías].

${ }^{66}$ «Así, una ley prescribe a todos los ciudadanos celebrar el aniversario de la constitución, pero no prevé nunguna sanción con respecto a aquellos que se abstengan. Al no tener aparejada ninguna consecuencia jurídica la conducta contraria a la prescrita, la ciencia del Derecho no puede considerar a dicha ley como una norma jurídica» (TP1 77). 
De este modo KELSEN está en condiciones de conciliar dos tesis definitorias aparentemente incompatibles - que el Derecho es un sistema normativo de normas positivas, y que es un sistema normativo coherente, que es una unidad dinámica y al mismo tiempo también una unidad lógica-. El material jurídico es producido por los órganos investidos de poder normativo - abreviando, el legislador- mediante decisiones que pueden ser contradictorias; el sistema jurídico es, en cambio, fruto de un proceso de interpretación que está sujeto a exigencias lógicas.

Esta solución afecta de forma muy significativa al contenido y función de la norma fundamental. Como sabemos, KELSEN atribuye a la norma fundamental de un sistema jurídico, como sistema dinámico, el cometido de dotar de autoridad a un órgano de producción de normas, el cual a su vez puede delegar en otros órganos: la unidad del sistema queda garantizada por la unidad de una cadena continua de delegación de poderes de producción normativa. Pero, como es notorio, KELSEN asigna a la norma fundamental un status lógico-transcendental, como condición de posibilidad de la ciencia jurídica, y del conocimiento del Derecho en general ${ }^{67}$. La suposición de la norma fundamental es la condición necesaria para que podamos comprender e interpretar los diversos materiales jurídicos — resultantes de actos de voluntad de órganos diversos, en momentos diferentes, y bajo restricciones de todo tipo- como un todo dotado de sentido y accesible a una «interpretación racional». Precisamente por eso la norma fundamental no puede limitarse a instituir una autoridad con poder para crear normas, pues eso no garantiza en absoluto unidad lógica - la sola instauración de una autoridad normativa conferiría validez a cualquier contenido-. La norma fundamental tiene también que ser garante de que lo producido por los órganos jurídicos sea interpretado como una unidad dotada de sentido.

«La hipótesis de la norma fundamental no significa otra cosa que la expresión de las condiciones necesarias del conocimiento jurídico [...] La función de la norma fundamental es ciertamente ante todo el establecimiento de una autoridad superior de producción jurídica, es, por tanto, ante todo delegación. Pero no se agota en eso. La norma fundamental no dice sólo "es Derecho lo que estatuye esta autoridad y porque lo estatuye, y nada más que lo que ella estatuye". Contiene también la garantía de que lo producido de ese modo puede ser concebido con sentido (sinnvoll)» (PG 299, cursivas mías)

La norma fundamental tiene, pues, que contener algo más que «una pura delegación»; en particular tiene que suministrar recursos para hacer efectiva la exigencia de coherencia y unificar lógicamente el sistema. Sólo así entendida está en condiciones de fundamentar el Derecho como sistema normativo no sólo dinámico sino también coherente. KELSEN es explícito:

«El sentido de la norma fundamental constitutiva de un orden jurídico no puede ser entendido — como correspondería a la idea de la positividad — como una pura delegación. La norma fundamental no puede significar el mero establecimiento de un órgano de creación de Derecho. Es cierto que hay que mantener lejos de la norma fundamental todo con-

67 «Si podemos aplicar per analogiam un concepto de la teoría kantiana del conocimiento (la norma fundamental) es la condición lógico-transcendental de los juicios mediante los cuales el sentido subjetivo del acto constituyente y de los actos realizados de acuerdo con él son interpretados como su sentido objetivo, y las normas que son el sentido subjetivo de dichos actos como normas objetivamente válidas, es decir, vinculantes. La presuposición de la norma fundamental es la condición verificada por la ciencia jurídica en el curso de un análisis de esos juicios. Sin ella esos juicios no son posibles, y por consiguiente tampoco lo son las interpretaciones que resultan de ellos» [BRO 1399 (98)]. 
tenido que determine las normas del orden jurídico fundamentado por ella en el sentido de alguna «justicia» material, absoluta. Pero si el sistema de normas jurídicas positivas erigido sobre la norma fundamental ha de ser un todo dotado de sentido (sinnvolles Ganze), una construcción comprensible, un posible objeto de conocimiento [...], entonces la norma fundamental misma tiene que ofrecer una garantía de ello. Lo que tiene que ofrecer no es ciertamente fundamentar un orden justo, sino fundamentar un orden dotado de sentido. Con ayuda de la norma fundamental tiene que poder concebirse el material jurídico creado positivamente (durch Satzung) como un todo dotado de sentido, lo cual significa que tiene que poder ser interpretado racionalmente» (PG 295).

Si la norma fundamental es el fundamento último de la validez de las normas del sistema, $y$, como hemos visto, la relación de validación entre normas está sujeta a exigencias lógicas, la norma fundamental unifica el Derecho constituyéndolo en una unidad al mismo tiempo dinámica y lógica. Una vez que admitimos que la coherencia - y no sólo la producción regular - forma parte de las condiciones de validez de las normas ${ }^{68}$, tenemos que considerar incluidas en la norma fundamental un conjunto de reglas de interpretación del material jurídico que garanticen coherencia disolviendo las antinomias. No necesitamos entrar todavía a examinar las reglas que según KELSEN cumplen esa función ${ }^{69}$. Independientemente de cuáles sean, lo cierto es que ahora tenemos que aceptar que la norma fundamental tiene un contenido mucho más complejo de lo que tendemos a pensar - más desde luego de lo que en ocasiones el mismo KELSEN parece querer dar a entender-. De acuerdo con la versión standard, la norma fundamental de un orden jurídico positivo se limita a investir de autoridad normativa a un poder jurídico básico, al que, para simplificar, podemos denominar «poder constituyente». De modo que en una formulación abreviada tendría un tenor parecido al siguiente: «Debe hacerse lo que establezca el poder constituyente $\mathrm{P}{ }^{70}$. Pero desde el momento en que KELSEN la erige en garante de la coherencia del sistema, hemos de pasar a concebirla como un complejo algoritmo ${ }^{71}$ en el que está integrado un conjunto de reglas que, por así decirlo, permiten filtrar y configurar el «material que se le ofrece al conocimiento jurídico», transformándolo en un sistema, esto es, en un conjunto coherente de normas (válidas).

Ahora bien, esta concepción arrastra consecuencias que tendrían que resultar incómodas para un positivista declarado, y particularmente militante, como KELSEN: i) en

68 «La norma fundamental dice que en condiciones determinadas (o a determinar) se establece como debida una consecuencia determinada (o a determinar). Pero con eso dice que en las mismas condiciones esa consecuencia no se establezca al mismo tiempo como no debida. Pues en la idea de ley tiene que estar incluido (mitgesetzt) el principio de contradicción, porque sin él se anularía toda idea de legalidad (Gesetztlichkeit)» (PG 299 y ss.).

69 Vid. más abajo el primer Excurso.

70 Para ser exactos, KELSEN ofrece una formulación más compleja. Dado que para él las normas jurídicas enlazan un supuesto de hecho a un acto de coacción, la norma fundamental de un sistema jurídico tiene que reflejar en su propio tenor esa función suya de dotar de autoridad normativa a un poder capaz de producir normas de ese tipo. «La norma fundamental de un orden jurídico prescribe que uno debe comportarse tal como mandan los "padres" de la constitución y los individuos directa o indirectamente autorizados (delegados) por la Constitución. Expresado en la forma de una norma jurídica: los actos coactivos deben realizarse sólo en las condiciones y en la forma determinadas por los «padres» de la constitución o por los órganos delegados por ellos» [GT 115 y ss. (135 y ss.)].

${ }_{71}$ Tomo la expresión de J. M. PéREz BERMEjo, quien lo introduce dentro de una caracterización general de las concepciones fundacionalistas del sistema jurídico. Vid. su Coherencia y sistema jurídico, Madrid, Marcial Pons, 2006, p. 91. 
primer lugar, parece poner en entredicho la tesis positivista sobre las fuentes sociales del Derecho, y ii) en segundo lugar, parece destruir aquella distancia, aseguradora de neutralidad, entre el conocimiento y su objeto, que de forma característica afirma el positivismo jurídico.

i) Para KELSEN el Derecho es un sistema normativo integrado por normas positivas; precisamente uno de los motivos de su insistencia en distinguir entre sistemas estáticos y dinámicos era explicar la naturaleza positiva del Derecho. Es cierto que KELSEN acepta que el sistema jurídico descansa todo él en una norma no-positiva, a saber, la norma fundamental, pero si se acepta el principio de la inderivabilidad del deber ser a partir del ser, su teoría de la validez de las normas jurídicas hace inevitable aceptar también que la norma fundamental del sistema no puede ser ella misma una norma positiva. En este sentido la norma fundamental, admite KELSEN sin ambages, es «un límite a la idea de positividad jurídica» (PG 294). Ahora bien, desde el momento en que le asigna el papel de garante de la coherencia del sistema tiene que admitir también que esa norma no positiva que es la norma fundamental contiene toda una batería de reglas o principios de interpretación que permiten eliminar antinomias restaurando la unidad lógica del sistema. Igual que la norma fundamental, tampoco esas reglas pueden ser positivas ${ }^{72}$. Aunque, obviamente, son susceptibles de ser positivizadas, no son reglas convencionales: forman parte del Derecho - de todo sistema jurídico- sin necesidad de haber sido introducidas mediante actos de producción normativa. Pero una vez que admitimos este punto, tenemos que aceptar también que el contenido de un sistema jurídico no es sólo producto de decisiones. KELSEN afirma que «el positivismo significa ciertamente que sólo es Derecho el producido siguiendo el procedimiento conforme con la constitución, pero no que tenga que admitirse como Derecho todo lo producido de ese determinado modo y especialmente no que tenga que admitirse como Derecho en el sentido que él mismo se atribuye» (PG 298). Pero para poder filtrar el material, discriminando del conjunto de lo «producido siguiendo el procedimimento» aquello que es Derecho y aquello que realmente no lo es, el sistema tiene que disponer de más ingredientes que normas positivas. En suma, desde el momento en que KELSEN afirma que la coherencia es una propiedad del Derecho como sistema, y que la norma fundamental tiene que garantizarla, se ve obligado a admitir que el sistema mismo no puede contener sólo normas positivas. Puesto que ha de satisfacer ciertas exigencias lógicas de racionalidad, no puede estar integrado de forma exhaustiva por normas positivas cuya validez descanse simplemente en el hecho de haber sido creadas regularmente; tiene que contener principios no convencionales de interpretación que permitan asegurar coherencia.

ii) La doctrina de la coherencia necesaria del Derecho presupone que no existe correspondencia estricta entre las disposiciones jurídicas y las normas, entre el material

72 En realidad KeLSEN no se detiene a discutir con detalle el status de las reglas de disolución de contradicciones normativas. Pero resulta claro que da por supuesto que no se trata de reglas positivas. En PG 296 señala que los conflictos lógicos entre normas han de resolverse «por vía de interpretación»; y al explorar algunas de las reglas de solución de antinomias insiste en que no son normas de Derecho positivo, sino «principios de interpretación presupuestos», sin los cuales no es posible dar sentido al material jurídico: sólo la aplicación de esas reglas permite una interpretación coherente del material jurídico. En algunos casos «esas interpretaciones son reinterpretaciones sin base jurídico-positiva, en contradicción con el tenor literal y el sentido pretendido, es decir, subjetivo, del material jurídico que ha de interpretarse» (PG 297, cursivas mías). 
legislativo y el sistema jurídico. Es el conocimiento jurídico — de forma particularmente relevante, la ciencia jurídica- el que pone las reglas que permiten extraer de las disposiciones jurídicas normas. Pero eso implica que el conocimiento jurídico crea su propio objeto: utilizando una expresión kantiana nada impertinente, el conocimiento jurídico opera la síntesis que configura el material legislativo y permite transformarlo en sistema jurídico, esto es, en Derecho. Pero lo hace conformándolo a sus propias exigencias de racionalidad. En ese sentido la ciencia jurídica tiene un papel activo en relación con su propio objeto: el Derecho, en tanto que sistema, no está meramente dado, sino que es un constructo de la ciencia jurídica, que al construirlo lo somete a sus propias leyes.

Volviendo a la tesis de las fuentes sociales del Derecho, podemos ahora reformularla en los siguientes términos. Las fuentes del Derecho se encuentran en actos de voluntad (de ciertas personas investidas de podes de producción normativa), pero esos actos de voluntad sólo producen el «material» del Derecho - las disposiciones jurídicas, no propiamente las normas-. El Derecho, como sistema de normas (a diferencia de un conglomerado de disposiciones jurídicas), es un constitutum, una construcción de la ciencia jurídica, que de ese modo es también en cierto modo fuente del Derecho.

\subsection{Transición}

En la segunda edición de la Reine Rechtslehre, de 1960, KeLSEN inició un interesante cambio de posición, que, sin embargo, no habría de consumarse todavía en esa obra. Ese cambio estaba ligado a una reconsideración del papel de la lógica en el Derecho $^{73}$.

La tesis inicial de la coherencia como una propiedad necesaria del sistema jurídico descansaba en el presupuesto de que las relaciones entre las normas están sujetas a exigencias lógicas y que, por consiguiente, pueden darse también contradicciones, es decir, conflictos lógicos. Ahora KELSEN niega que los principios lógicos (en particular el principio de contradicción) sean aplicables a las normas, porque no admite que entre ellas haya relaciones lógicas. La lógica, afirma KELSEN, se ocupa de las condiciones formales de verdad/falsedad que se dan entre enunciados. Relaciones lógicas sólo son posibles entre enunciados asertóricos o descriptivos, únicos susceptibles de ser discutidos desde el punto de vista de la verdad. La lógica nada tiene, en cambio, que ver con las normas, que son prescripciones formuladas en enunciados deónticos: las normas pueden ser válidas o inválidas, no verdaderas o falsas. Ahora bien, si no puede haber relaciones lógicas entre normas, entonces, hablando con propiedad tampoco puede haber contradicciones —es decir, conflictos lógicos- entre normas. El principio de contradicción rige para los enunciados asertóricos: contradictoria es la conjunción de los enunciados «es a»y «no es a», porque ambos enunciados no pueden ser verdaderos. Pero no rige para las normas, de las que no puede predicarse verdad o falsedad.

73 Sobre el particular, vid. T. MAZZARESE, Logica deontica e linguaggio giuridico, Padova, Cedam, 1989, pp. 115 y ss. Para hacerse cargo de este cambio de posición es muy instructivo el intercambio epistolar entre Kelsen y Klug recogido en H. KelSEN y U. Klug, Normas jurídicas y análisis lógico, trad. de J. C. Gardella, Madrid, CEC, 1988. 
Puede que lo que denominamos «antinomia» - la existencia de dos normas, una de las cuales dice «debe ser a», mientras las otra dice «no debe ser a»- represente una deficiencia para un sistema normativo, pero en todo caso no es una contradicción, es decir, una deficiencia lógica, porque entre normas se dan relaciones de validación pero no relaciones lógicas.

«No puede ignorarse la posibilidad de que de hecho los órganos jurídicos establezcan normas que están entre sí en conflicto [...] Semejante conflicto de normas se da cuando una norma determina una conducta como debida y la otra determina como debida una conducta incompatible con ella [...] Este conflicto no es [...] una contradicción lógica en sentido estricto, aunque suele decirse que las dos normas se «contradicen». Pues los principios lógicos, y en especial el principio de contradicción, sólo son aplicables a enunciados susceptibles de ser verdaderos o falsos, y una contradicción lógica entre dos enunciados consiste en que sólo uno u otro enunciado puede ser verdadero, pues si uno es verdadero el otro tiene que ser falso. En cambio, una norma no es ni verdadera ni falsa, sino válida o inválida» [RR 209 ss. (214), cursivas mías].

Ahora bien, esta importante modificación en el presupuesto de partida no conduce a KELSEN (todavía) a abandonar enteramente su posición inicial. A pesar de negar que existan relaciones lógicas entre normas, sigue afirmando que la «unidad lógica» es una propiedad del sistema jurídico. Para hacer compatibles estas dos ideas KeLSEN, i) echa mano de la distinción entre normas jurídicas (Rechtsnormen) y proposiciones jurídicas (Rechtssätze $)^{74}$, y a continuación ii) introduce en el sistema la exigencia de coherencia a través de las proposiciones jurídicas.

i) La distinción entre normas jurídicas y proposiciones jurídicas es una distinción entre dos niveles de lenguaje: el nivel del lenguaje en el que se expresa el Derecho y el del lenguaje en el que se produce el discurso de la ciencia jurídica sobre el Derecho. Las normas jurídicas son «mandatos, y en cuanto tales imperativos» [RR 73 (84)] que indican que en determinadas circunstancias deben realizarse determinadas conductas -aunque KELSEN se apresura a precisar que bajo la expresión «imperativo» han de englobarse no sólo los mandatos sino también las permisiones y las autorizaciones-. Las proposiciones jurídicas, en cambio, son enunciados asertóricos de la ciencia jurídi$\mathrm{ca}^{75}$ a propósito del Derecho: «son juicios hipotéticos que enuncian que en el sentido de un [...] orden jurídico dado al conocimiento, y en ciertas condiciones determinadas por ese orden jurídico, deben producirse determinadas consecuencias» [RR 73 (84), cursivas mías]. Si en ocasiones no se tiene clara esta distinción es porque normas y proposiciones jurídicas pueden servirse de los mismos recursos lingüísticos: en la medida en que se formulen lingüísticamente, también las normas adoptan la forma de enunciados hipotéticos que enlazan mediante el nexo de la imputación determinadas

74 Vid. RR $\$ 16$. He de advertir que en la versión española de la segunda edic. de la Reine Rechtslebre Satz se ha traducido por «enunciado». Para mantener la distinción entre Satz y Aussage, prefiero traducirla por «proposición».

75 Para que no haya dudas: aunque la ciencia jurídica es el «sujeto» predilecto para la emisión de proposiciones jurídicas, es obvio que no es el único. No sólo formulan proposiciones jurídicas los científicos del Derecho. También lo hacen los abogados cuando asesoran a sus clientes apoyándose en el Derecho vigente, los ciudadanos cuando se informan unos a otros sobre su situación jurídica, los historiadores del Derecho cuando informan sobre un ordenamiento jurídico histórico, etc. Así pues, la referencia, aquí y en otros lugares, «ciencia jurídica» ha de entenderse como una abreviatura de la que (siguiendo fielmente, creo yo, a KELSEN) me sirvo para referirme a cualquier forma de actividad cognitiva en relación con el Derecho 
consecuencias a determinados supuestos de hecho. Ello no debe, sin embargo, hacernos perder de vista el distinto sentido que tienen en uno y otro caso. Las normas son resultado de actos de voluntad creadores de Derecho, las proposiciones jurídicas son resultado de actos de conocimiento mediante los que se elabora y suministra información a propósito de «un orden jurídico dado al conocimiento». El deber ser (Sollen) expresado en ambas tiene un sentido enteramente diferente: «el deber ser de la proposición jurídica no tiene, como el deber ser de la norma jurídica, un sentido prescriptivo sino descriptivo» [RR 77 (88)]. La pertenencia a juegos de lenguaje —-descriptivo, prescriptivo - $\tan$ diferentes afecta a la naturaleza de las pretensiones epistémicas de unas y otras ${ }^{76}$. Las normas jurídicas no pueden discutirse desde el punto de vista de la de verdad, aunque sí, obviamente desde el punto de vista de la validez; y su validez o invalidez (vale decir, su existencia y su pertenencia al sistema) depende básicamente de si fueron o no creadas por un acto autorizado por otra norma del sistema. Las proposiciones jurídicas, en cambio, en tanto que enunciados asertóricos que «describen la validez» [RR 77 (88)] de una norma, sí pueden ser discutidas desde el punto de vista de la verdad, y su verdad o falsedad depende de si realmente existen o no (e. d. si son válidas o no) las normas sobre las que versan.

En la trayectoria intelectual de KELSEN la formulación de la distinción entre normas jurídicas y proposiciones jurídicas, que hoy es moneda corriente, fue relativamente tardía, y vino favorecida por el progresivo abandono de su concepción inicial sobre la naturaleza de las normas jurídicas. En su primera gran obra - los Hauptprobleme de 1911- KELSEN había defendido de forma particularmente beligerante una teoría no imperativista de las normas jurídicas ${ }^{77}$, que sin embargo debería compaginarse con su visión voluntarista del Derecho. Aunque las normas jurídicas son «expresión de la voluntad del Estado» [HP 189 (163)], sería erróneo, pensaba KELSEN, concebirlas como mandatos, como imperativos: las normas son más bien juicios (Urteile) que enlazan mediante el nexo de la imputación determinadas consecuencias a determinados supuestos de hecho. Los meros mandatos son manifestaciones de la voluntad, y en este sentido permanecen en la esfera del Sein. En cambio, «la proposición (Satz): «Debes...» es un juicio y nada más que un juicio, en el que sobre el sujeto «tú» se enuncia el predicado «deber ser». Ahora bien, aunque desde el punto de vista lógico-formal la frase «Debes...» no puede ser más que un juicio y nunca un imperativo, ese juicio puede estatuir un deber ser igual que un imperativo; y por eso en deterrminadas circunstancias ese juicio puede funcionar como una norma» $[\mathrm{HP} 211(181)]^{78}$. La insistencia en que las

76 «Las proposiciones deónticas (Sollsätze) formuladas por la ciencia jurídica [...] pueden ser verdaderas o falsas, mientras que las normas deónticas (Sollnormen) puestas por la autoridad jurídica no son ni verdaderas ni falsas sino válidas o inválidas» [RR 75 y ss. (86)].

77 Aunque es pertinente toda la sección segunda del libro segundo de los Hauptprobleme, vid. especialmente el cap. VII.

78 Trece años después de la publicación de los Hauptprobleme KELSEN, en el prólogo a la segunda edición de esa obra, expresa su posición en los siguientes términos. «La proposición jurídica (Rechssatz) como expresión de la específica legalidad jurídica (Rechtsgesetztlichkeit), como la ley del Derecho (Rechtsgesetz), es para mí el problema medular, y desde este punto de vista el Derecho de la ciencia jurídica [a diferencia del de la sociología] se presenta como un sistema de proposiciones jurídicas, como una conexión de juicios (Urteilszusammenhang), igual que para la filosofía transcendental la naturaleza de la ciencia natural se presenta como un sistema de juicios; sólo que esos juicios expresan la legalidad de la conexión natural, mientras que en la proposición jurídica se manifiesta la específica legalidad (Gesetztligkeit) del Derecho. Igual que en el juicio de la ley natural, también en la proposición jurídica se enlaza una determinada consecuencia a una determinada condición; sólo 
normas jurídicas son juicios hacía casi inevitable situar el Derecho inmediatamente en el campo de aplicación de la lógica, y favorecía una cierta indistinción entre las normas jurídicas y las proposiciones mediante las que la ciencia jurídica formula las normas. Aunque KELSEN mantuvo hasta el final un especial cuidado en distinguir las normas de los meros mandatos, lo cierto es que con el paso del tiempo, y probablemente por el contacto con la tradición de la jurisprudencia analítica, acentuado en los años cuarenta a raíz del exilio en Norteamérica, fue abandonando esa posición inicial tan marcadamente anti-imperativista, y ello, creo yo, facilitó la distinción entre las normas jurídicas y las proposiciones de la ciencia jurídica.

ii) La distinción Rechtsnormen/Rechtssätze, tal como se presenta en la segunda edición de la Reine Rechtslehre, no es realmente nueva en KELSEN. Esa distinción ya había quedado registrada de forma temática en la General Theory of Law and State (1945) ${ }^{79}$ y en la versión francesa de 1953 de la Reine Rechtslebre ${ }^{80}$. Lo que es nuevo es la consecuencia que de ella extrae para el tema de las contradicciones normativas. Puesto que las normas no pueden discutirse desde el punto de vista de la verdad, las relaciones entre normas no están sujetas a los principios lógicos, en particular al principio de contradicción. Por ello, hablando con rigor, no existen contradicciones entre normas, si por tales entendemos incompatibilidades lógicas. Es cierto que el legislador puede establecer normas que coloquen al destinatario en una posición imposible porque no puede cumplir una sin violar la otra. Pero eso no representa un problema lógico, ya que la lógica no juega aquí ningún papel.

Hay aquí sin duda un importante cambio en el planteamiento inicial. Inicialmente el fenómeno de las antinomias había quedado situado en el terreno de las disposiciones jurídicas: prescripciones lógicamente incompatibles pueden presentarse en el «material jurídico que se le presenta al conocimiento», pero no en el Derecho como sistema de normas válidas. El fenómeno se desplaza ahora hacia el terreno de las normas -aunque no bajo la forma de un conflicto lógico, no caracterizado como una contradicción. Una vez dado ese paso, KELSEN podría haberse desembarazado del fenómeno como si representara un problema puramente factual, tal vez importante, pero irrelevante para la integración del Derecho como sistema: la presencia de normas que prescriben de forma incompatible - podría haber dicho- es un hecho lamentable, pero en la medida en que la validez de las normas no está sujeta a exigencias lógicas, carece de significación a los efectos de la unificación de una multiplicidad de normas en esa unidad que denominamos «sistema». KELSEN, sin embargo, parece retroceder ante esa consecuencia, y todavía quiere mantener la idea de la unidad lógica del Derecho en el

\footnotetext{
que en lugar del nexo causal que allí liga la consecuencia a la condición, aquí entra otro principio de enlace. El deber ser expresa el sentido en el que la posposición jurídica une un supuesto de hecho como condición al otro como consecuencia jurídica» [HP VI (XL)]. Obsérvese que en este pasaje (como, por lo demás, a lo largo de toda la obra) la expresión Rechtssatz aparece para designar la formulación canónica de las normas jurídicas más que los enunciados (metalingüísticos) de la ciencia jurídica. En realidad es inútil buscar en los Hauptprobleme la distinción posterior entre Rechtsnorm y Rechtssataz. Cuando años más tarde KELSEN afirma que el uso de esas dos expresiones como sinónimas es síntoma de una tendencia de la ciencia del Derecho a confundir «la función cognitiva de la ciencia del Derecho» con la función normativa de la autoridad jurídica» [RR 74 n. (85 n.)], está formulando indirectamente una observación que en realidad le habría sido aplicable a él mismo.

79 Vid. GT 45 (52 y ss.) donde la distinción aparece bajo los términos legal norm y rule of law in a descriptive sense.

${ }^{80}$ Vid. TP2 45 y ss.
} 
sentido de la ausencia de contradicciones. Y para eso le resulta útil la distinción entre normas jurídicas y proposiciones jurídicas: aunque los principios lógicos, y en particular el principio de contradicción, no son directamente aplicables a las normas, sí lo son «indirectamente», a saber, a través de las proposiciones jurídicas — v. gr. a través de los enunciados de la ciencia jurídica que informan sobre las normas que están vigentes en un país. Si las proposiciones jurídicas, como enunciados asertóricos que son, están sujetas a los principios lógicos, entonces la descripción de un sistema jurídico $(v \cdot g r$. por la ciencia jurídica) tiene que llevarse a cabo mediante un sistema de enunciados libre de contradicciones. Por eso KELSEN admite que, aunque, en rigor, no es correcto hablar de contradicciones lógicas entre normas, esa forma de hablar tiene cierto sentido:

«Dado que las normas jurídicas, en tanto que prescripciones —es decir, como mandatos, permisiones, autorizaciones — no pueden ser verdaderas ni falsas, se plantea la cuestión de cómo pueden aplicarse los principios lógicos, en particular el principio de contradicción y las reglas de inferencia, a la relación entre normas jurídicas (tal como desde siempre ba hecho la teoría pura del Derecho) ${ }^{81}$, si, con arreglo a la visión tradicional, esos principios sólo son aplicables a enunciados que pueden ser verdaderos o falsos. La respuesta a esta pregunta es que los principios lógicos pueden aplicarse a las normas jurídicas (Rechtsnormen), si no directamente, sí indirectamente en la medida en que son aplicables a las proposiciones jurídicas (Rechtssätze) que describen esas normas jurídicas, y que sí pueden ser verdaderas o falsas. Dos normas jurídicas se contradicen y, por consiguiente, no pueden ser afirmadas al mismo tiempo como válidas cuando las dos proposiciones jurídicas que las describen se contradicen; y una norma jurídica puede ser derivada de otra, cuando las proposiciones jurídicas que las describen pueden entrar en un silogismo» [RR 76 y ss. (87 y ss.), cursivas mías].

Así, pues, KELSEN parece pensar ahora que aunque, hablando con propiedad, una norma que manda hacer $a$ y otra que prohíbe hacer $a$ no constituyen una contradicción, la conjunción de los enunciados que describen esas mismas normas como normas que forman parte del mismo sistema $(v, g r$, el enunciado «En Derecho español es obligatorio hacer $a$ y está prohibido hacer $a \gg)$ sí constituye una contradicción. Y eso le lleva a afirmar que, aunque, hablando con propiedad, los conflictos entre normas no puedan ser catalogados como contradicciones, es decir, como conflictos lógicos, ciertamente son un absurdo lógico, un sinsentido, porque no pueden ser descritos en proposiciones con sentido. Por eso podemos denominarlos «contradicciones» de un modo traslaticio. Ahora bien, si esto es así, entonces la norma fundamental, que tiene que hacernos posible concebir como un todo normativo dotado de sentido el producto de un conjunto de actos de creación de normas, tiene que proporcionar los recursos necesarios para eliminar los conflictos de normas. En este sentido la norma fundamental, que fundamenta la validez de las normas, mantiene todavía su función inicial de guardián y garante de la coherencia, operando como filtro ${ }^{82}$ :

81 Obsérvese esta significativa confesión de KELSEN.

82 En este punto me desvío de la interpretación de J. Delgado PinTo, para quien los principios de interpretación que resuelven los conflictos de normas ya no forman parte del «significado de la norma fundamental». KELSEN, dice DELGADO PINTO, más bien «parece considerarlos como criterios o recursos lógicos de toda interpretación jurídica, que no necesitan estar contenidos en norma alguna» («El voluntarismo de Hans Kelsen...», op. cit., p. 131). Es verdad que en RR KELSEN no afirma explícitamente, como hacía en PG, que la norma fundamental es la garante de la coherencia y que por tanto ha de contener los recursos necesarios para asegurarla. Pero ¿de qué otro modo hemos de interpretar el pasaje que se acota a continuación? Si la norma fundamental «no suministra el sentido objetivo de una norma válida a cualquier acto», si en particular no lo 
«...la norma fundamental no suministra el sentido objetivo de una norma válida a cualquier acto, sino sólo a aquel que tienen el sentido subjetivo de que los hombres deben comportarse de un determinado modo. Ese acto tiene que ser -en sentido normativo - un acto pleno de sentido. Si tiene otro sentido - v. gr. el sentido de un enunciado ( $v . g r$ una teoría presentada en una ley) - o no tiene ningún sentido - cuando la ley contiene palabras sin sentido o determinaciones que son incompatibles entre sí- no entra en consideración ningún sentido subjetivo que pueda interpretarse como el sentido objetivo, no estamos ante ningún acto cuyo sentido subjetivo sea susceptible de ser legitimado por la norma fundamental» [RR 211 (216), cursivas mías].

En el epígrafe 34.e) de la 2. ${ }^{a}$ ed. de la Reine Rechtslebre - bajo el significativo título «La unidad lógica del orden jurídico»-, KELSEN reformuló su tesis inicial sobre el sistema jurídico como una unidad al mismo tiempo dinámica y lógica en un pasaje que merece ser reproducido in extenso:

«Dado que la norma fundamental es el fundamento de validez de todas las normas que pertenecen al mismo orden jurídico, ella constituye la unidad de una pluralidad de esas normas. Esa unidad se expresa en que un orden jurídico puede ser descrito en proposiciones jurídicas que no se contradicen entre sí. Naturalmente no puede ignorarse la posibilidad de que de hecho los órganos jurídicos establezcan normas que están entre sí en conflicto [...] Semejante conflicto de normas se da cuando una norma determina una conducta como debida y la otra determina como debida una conducta incompatible con ella [...] Ese conflicto no es [...] una contradicción lógica en sentido estricto, aunque suele decirse que las dos normas se «contradicen». Pues los principios lógicos, y en especial el principio de contradicción sólo son aplicables a enunciados susceptibles de ser verdaderos o falsos, y una contradicción lógica entre dos enunciados consiste en que sólo uno u otro enunciado puede ser verdadero, pues si uno es verdadero el otro tiene que ser falso. En cambio, una norma no es ni verdadera ni falsa, sino válida o inválida. Pero el enunciado que describe un orden normativo, de que con arreglo a ese orden vale una determinada norma [...] sí puede [...] ser verdadero o falso. De ahí que los principios lógicos en general, y el principio de contradicción en particular, pueden aplicarse a las proposiciones que describen el Derecho, y con ello también indirectamente a las normas jurídicas. Por ello no va en absoluto tan descaminado quien dice que dos normas jurídicas se «contradicen» entre sí. Que A deba ser y al mismo tiempo no deba ser es tan carente de sentido como que A es y al mismo tiempo no es. Un conflicto de normas representa algo tan carente de sentido como una contradicción lógica.

Pero dado que el conocimiento del Derecho - como todo conocimiento- persigue concebir su objeto como un todo lleno de sentido y describirlo en proposiciones libres de contradicciones, parte del supuesto de que los conflictos de normas pueden y tienen que ser disueltos en el curso de la interpretación» [RR 209 y ss. (214 y ss.) cursivas mías].

Como se ve, KELSEN admite que el legislador puede incurrir en el tipo de conflicto normativo que denominamos «antinomia», esto es, puede establecer normas incompatibles o «contradictorias» (pongámoslo así, entre comillas), pero insiste en que el sistema jurídico es coherente porque la ciencia jurídica puede (y tiene que) depurarlo eliminando los conflictos. Carlos AlChOURRÓN y Eugenio BULYGIN han denunciado esta estrategia teórica en los siguientes términos

«Lo que KeLSEN dice aquí [a propósito de la capacidad de la ciencia jurídica para disolver contradicciones] suena un poco optimista, pero es sustancialmente verdadero. Sin embargo, lejos de apoyar su tesis de que todos los sistemas jurídicos son siem-

hace en relación con las leyes que contienen «determinaciones que son incompatibles entre sí», ¿̇no se erige en garante de la coherencia del sistema? 
pre coherentes, prueba que esta tesis es falsa. En efecto, si las contradicciones han de ser eliminadas, entonces hay tal cosa como una contradicción que debe ser eliminada. Q. E. D.» ${ }^{83}$.

Obsérvese que este reproche habría estado fuera de lugar aplicado a la posición inicialmente defendida por KELSEN, pues desde el momento en que él establecía la coherencia como condición de validez de las normas, estaba en condiciones de rechazar la existencia misma de normas contradictorias: las antinomias se producen entre disposiciones jurídicas, pero no entre normas; son un fenómeno del «material que se ofrece al conocimiento», no del sistema jurídico elaborado precisamente por el conocimiento jurídico obedeciendo principios lógicos ${ }^{84}$. El reproche de AlCHOURRÓN y BuLYGIN es, en cambio, pertinente aplicado a la posición defendida por KELSEN en la segunda edición de la Reine Rechtslebre. Como hemos visto, una concepción imperativista de las normas le permite ahora negar que la coherencia forme parte de la validez de las normas, y ello le conduce a resituar el fenómeno de las antinomias desplazándolo desde las disposiciones jurídicas a las normas mismas: puede haber normas incoherentes entre sí, pues la coherencia no es relevante como condición de validez de las normas, $y$ sin embargo las incoherencias tienen que eliminarse «en el curso de la interpretación», porque el sistema ha de ser descrito como un todo lleno de sentido. Ahora bien, afirmar que el sistema jurídico es coberente porque está en condiciones de eliminar las incoherencias que puedan presentarse entre sus normas es ciertamente una forma paradójica de hablar. Esa paradoja se explica, sin embargo, por la confusa concepción que KELSEN mantiene a propósito de la relación entre la ciencia jurídica y su objeto, que conduce a una concepción muy problemática de la norma fundamental como fundamento de la validez de las normas.

KELSEN introduce la distinción entre normas y proposiciones jurídicos en el marco de un intento de aclarar la naturaleza de la ciencia jurídica. La ciencia jurídica es una ciencia descriptiva, integrada por proposiciones jurídicas, es decir, enunciados asertóricos cuyo cometido es suministrar información sobre el contenido normativo de un determinado orden jurídico como objeto «dado al conocimiento». Desde este punto de vista el sistema jurídico es previo a la ciencia jurídica, está preconstituido: «La ciencia jurídica es conocimiento del Derecho, no configuración del mismo» [RR 74 (86) n.] ${ }^{85}$. Y sin embargo, KELSEN no puede dejar de seguir pagando tributo a una visión neokantiana, muy fuertemente arraigada en él, sobre el carácter productivo del conocimiento:

83 «La concepción expresiva de las normas», ahora en Análisis lógico y Derecho, op. cit., p. 142.

84 En la edición francesa de la Reine Rechtslebre, publicada en una fecha relativamente tardía, KELSEN, a pesar de haber introducido la distinción entre normas y proposiciones jurídicas (reglas de Derecho), sigue atribuyendo a la ciencia jurídica la capacidad para decidir sobre la validez de las normas jurídicas. «Podemos [...] afirmar simultáneamente que las reglas de Derecho son juicios formulados por la ciencia jurídica, y que el objeto de esta ciencia está constituido por normas jurídicas. No hay aquí ninguna contradicción. Sin duda puede considerarse que las normas jurídicas no tienen el carácter de normas jurídicas en tanto no sean reconocidas por la ciencia del Derecho» (TP2 48, cursivas mías).

${ }^{85} \mathrm{La}$ ciencia jurídica «describe las normas jurídicas creadas mediante actos de conducta humanos [...] y junto con ello las relaciones constituidas mediante esas normas jurídicas entre los supuestos de hecho determinados por ellas. Las proposiciones en las que la ciencia del Derecho describe esas relaciones, en tanto que proposiciones jurídicas, tienen que distinguirse de las normas jurídicas, que son creadas por los órganos jurídicos...» [RR $73(84)]$. 
«En el sentido de la teoría kantiana del conocimiento, la ciencia del Derecho, como conocimiento del Derecho, igual que todo conocimiento, tiene carácter constitutivo y por consiguiente «produce» su objeto en la medida en que lo concibe como un orden con sentido. Así como el caos de las percepciones sensoriales se convierte en un cosmos, es decir, en naturaleza como un sistema unitario, sólo mediante conocimiento ordenador de la ciencia, igualmente la multitud de las normas jurídicas generales e individuales establecidas (gesetzt) por los órganos jurídicos se convierte en un sistema unitario, libre de contradicciones, en un orden jurídico, sólo mediante el conocimiento de la ciencia jurídica. Pero esa «producción» tiene un carácter puramente gnoseológico. Es algo totalmente diferente de la producción de objetos mediante el trabajo humano o de la producción del Derecho mediante la autoridad jurídica» [RR 74 y ss. (85), cursivas mías].

Así concebida, la ciencia jurídica ocupa una posición ambigua: sus proposiciones describen las normas de un determinado sistema jurídico, pero al mismo tiempo las construyen. En el pasaje que acabo de transcribir se advierte la preocupación de KELSEN por puntualizar que la ciencia jurídica es productiva es un sentido diferente a como lo es la autoridad jurídica; pero lo cierto es que, si tiene confiada la función de asegurar coherencia, tiene que poder intervenir activamente en el material normativo producido por la autoridad jurídica ${ }^{86}$. Esa ambigüedad sobre la relación entre el conocimiento jurídico y su objeto tiene su reflejo en la naturaleza bifronte de la norma fundamental: como (última) norma del sistema, fundamento de la validez de las normas jurídicas, y como condición de posibilidad del conocimiento jurídico. En tanto que fundamento último de la validez de las normas, la norma fundamental unifica como sistema una multiplicidad de normas. Pero como es bien sabido, no es una norma jurídica, fruto de un acto de decisión de algún órgano jurídico; es más bien «una norma pensada» [RR 207 (212)], que necesariamente ha de «suponer» el conocimiento jurídico con el fin de hacer accesibles determinados fenómenos a una interpretación en términos normativos. En este sentido la suposición de la norma fundamental resulta ser al mismo tiempo el punto de referencia de la integración del sistema como una unidad y la condición de posibilidad de la ciencia jurídica: opera como fuente última de la validez de las normas y al mismo tiempo como garante de las exigencias lógicas que hacen del sistema un todo lleno de sentido accesible a una interpretación racional. Pero eso genera una situación paradójica: como fundamento último de la validez de las normas no puede contener reglas para la disolución de antinomias, puesto que las relaciones de validación entre normas no están sujetas a principios lógicos; pero como condición de posibilidad del conocimiento jurídico tiene que contener reglas que disuelvan las antinomias, puesto que ha de garantizar la coherencia del sistema como una «unidad lógica».

\section{Excurso I. Las reglas de disolución de las antinomias}

La afirmación kelseniana de que el Derecho es una unidad lógica implica que el sistema jurídico dispone de reglas capaces de disolver de forma inequívoca y, por así

${ }^{86}$ En nota a pie de página [RR 75 (86)] KELSEN ataca la tesis (que él atribuye a la teoría tradicional del Derecho) según la cual la ciencia jurídica contribuye a la configuración del Derecho. Pero lo cierto es que una vez que atribuye al conocimiento jurídico funciones de garante de la coherencia, se desdibujan las fronteras que él quiere trazar entre «conocimiento» y «configuración» del Derecho. 
decirlo, mecánica todos los conflictos lógicos entre normas. Independientemente de cuáles sean sus credenciales, las tres reglas tradicionales - lex superior, lex posterior, lex specialis - no son en este punto satisfactorias, porque, como es bien sabido, tienen una eficacia limitada: por un lado, no ofrecen solución a aquellos casos en los que las normas implicadas en la antinomia son indistinguibles desde el punto de vista de los tres criterios (jerárquico, cronológico y de especialidad) que permiten aplicarlas; por otro, tampoco la proporcionan en aquellos otros casos en los que concurren conflictivamente varias de ellas ${ }^{87}$. ¿Qué otra combinación de reglas podría asegurar coherencia en todos los casos? Si KELSEN no pudiera ofrecer una respuesta a esta pregunta, su tesis de la unidad lógica del sistema jurídico se vendría abajo. El examen de la respuesta de KELSEN mostrará que en efecto dispone de una batería de instrumentos interpretativos para afrontar las antinomias, pero que su aplicación en lugar de proporcionar solución a los conflictos de normas asegurando coherencia, más bien otorgan carta de naturaleza a las incoherencias, permitiendo que queden integradas en el sistema. El estudio de las reglas kelsenianas de solución de antinomias resulta así revelador en la medida en que saca a la luz lo confusa que termina siendo en KELSEN la idea del sistema como «unidad lógica» en el sentido de ausencia de contradicción.

\section{Las reglas}

Aunque KELSEN no lleva a cabo un estudio demasiado detallado, en diversos lugares ${ }^{88}$ y con algunas variaciones, realiza una exploración del tema distinguiendo varias situaciones.

i) Cuando la antinomia se produce entre normas del mismo rango pero promulgadas en momentos diferentes (y la antinomia es del tipo total-total o parcial-parcial), el conflicto se disuelve aplicando el principio lex posterior y, por tanto, anulando la norma promulgada con anterioridad ${ }^{89}$. KELSEN considera que ese principio está implícito en la norma fundamental del siguiente modo. Como sabemos, la norma fundamental de un sistema dinámico instaura una autoridad normativa, es decir un poder autorizado a crear normas. Pero a quien tiene poder para crear normas ha de suponérsele también poder para anular las normas anteriormente creadas. En este sentido el principio lex posterior, dice KELSEN, «está incluido en la autorización» [RR 210 (215)]: está presupuesto como principio de interpretación del material jurídico «porque sin ese presupuesto no puede interpretarse con sentido un orden jurídico transformable» (PG 296).

${ }^{87}$ El problema es bien conocido. Vid., por todos, el tratamiento de BoBBIO en Teoría general del Derecho, op. cit., Segunda Parte, cap. III, seccs. 69-70.

${ }^{88}$ V. gr. PG 295 y ss.; RR 210 y ss. [214 y ss.]; BRO 1400 y ss. [99 y ss.]. Es significativo que las reglas de disolución de antinomias reaparezcan incluso después de que KELSEN haya abandonado la idea de la coherencia intrínseca del sistema jurídico; vid. en este sentido D 352 y ss.; ATN 102 y ss., donde se constata que KELSEN sigue teniendo en mente las mismas reglas, aunque, como veremos, atribuyéndoles un status normativo diferente (vid. infra el segundo Excurso). Sobre las reglas kelsenianas es muy instructivo el análisis de J. RUIZ MANERO en Jurisdicción y normas, Madrid, CEC, 1990, pp. 57-67, y de J. AGUILÓ, en el capítulo primero de Sobre Derogación. Ensayo de dinámica jurídica, México, Fontamara, 1995.

89 Naturalmente en el caso de la antinomia parcial-parcial sólo se anula aquella parte del supuesto de hecho de la norma anterior que interseca con la posterior. 
ii) Es obvio que cuando la antinomia se produce entre normas dictadas por el mismo órgano y en el mismo acto ${ }^{90}$ el principio lex posterior es inaplicable. Ahora bien, dentro de este supuesto KELSEN parece distinguir dos casos:

a) Si la incompatibilidad es sólo parcial (antinomia total-parcial), ha de aplicarse el principio lex specialis, entendiendo que «una de las dos normas limita la validez de la otra» [RR 211 (215)] —expresándolo en los términos de GAVAZZI, «la norma más amplia queda privada de aquella parte de contenido que es regulada de forma diversa por la norma más estrecha»- ${ }^{91}$. Puntualizaré que si la incompatibilidad se da entre una norma prescriptiva y una norma permisiva y aceptamos el carácter parasitario de las normas permisivas como fragmentos de alguna norma prescriptiva ${ }^{92}$, la aplicación de la regla lex specialis produce lo que podemos denominar una «fusión conjuntiva» de las dos normas: al eliminar en el supuesto de la norma incluyente la zona de inclusión, hemos de contemplar el resultado como integrando una sola norma, que contiene una regla general y su excepción.

b) En cambio si la antinomia es total-total o parcial-parcial, se ha de entender que «el órgano autorizado a aplicar la ley ( $v$. gr. un tribunal) queda en libertad para elegir entre las dos normas» [RR 211 (215)]; en otras palabras, la solución de la antinomia se lleva a cabo «fundiendo disyuntivamente las dos normas en conflicto en una nueva norma que recoja a ambas como alternativas entre las que está facultado a escoger el órgano de aplicación» ${ }^{93}$. Por eso J. Aguiló denomina a este procedimiento «fusión disyuntiva de las normas» ${ }^{94}$. En lugar de dos normas que establecen «Debe ser a»y «Debe ser no a» tenemos una sola que establece «Debe ser a o no a» ${ }^{95}$.

iii) Problemas especiales plantean las antinomias en las que están envueltas normas de diferente rango. En este punto KELSEN ofrece una respuesta sorprendente. Como es sabido, la doctrina tradicional señala que en este caso es preciso respetar la idea de jerarquía normativa, tal como se expresa en la regla lex superior. Y en realidad

${ }_{90} \mathrm{O}$ normas promulgadas en el mismo momento por órganos diferentes autorizados para crear normas del mismo nivel —una situación improbable pero teóricamente posible.

91 G. Gavazzi, Delle Antinomie, Torino, Giapichelli, 1959, p. 81.

92 Vid. RR 56 y ss. [68].

93 J. RUIZ MANERO, Jurisdicción y normas, op. cit, p. 59.

94 J. Aguiló, op. cit., 34 y ss.

95 Tengo que agregar que KELSEN señala que en los casos en los que no es posible esa interpretación, debemos desentendernos de ambas normas, porque en ese caso «el legislador ha prescrito algo sin sentido, lo que existe es un acto de producción normativa sin sentido, y por tanto no existe ningún acto cuyo sentido subjetivo pueda ser interpretado como su sentido objetivo, y por consiguiente no existe ninguna norma objetivamente válida» [BRO 1401 (100); RR 211 (216); en términos parecidos se había expresado ya en PG 297]. En este caso diríamos que dos normas contradictorias se anulan recíprocamente produciendo una laguna por colisión. La verdad es que es difícil imaginar un caso de antinomia en el que el órgano encargado de aplicar el Derecho no pueda echar mano del recurso de la fusión disyuntiva de las normas. De una lectura atenta [vid. RR 212 (217)] parece desprenderse que si KELSEN plantea esta posibilidad tal vez no sea pensando en antinomias producidas por normas generales, sino más bien pensando en el caso —improbable, pero no imposible_ de una sentencia judicial que contenga dos fallos contradictorios: en este caso es el órgano mismo de aplicación del Derecho el que produce la antinomia, y KELSEN parece pensar que en este caso no hay ya oportunidad de recurrir a la fusión disyuntiva. Sea de ello lo que fuere, si la contemplamos en serio, esta posibilidad crea un problema: en este caso KELSEN ofrece dos soluciones a la antinomia — mantener ambas normas fundiéndolas disyuntivamente, o anular ambas - pero no ofrece ninguna regla para optar por una u otra, de modo que puede aplicarse cualquiera de las dos normas o ninguna de ellas. Esto significa que el caso queda enteramente entregado a la libre apreciación del órgano de aplicación de la norma. La «regla de solución de la antinomia» rezaría: «Que el caso se resuelva discrecionalmente». 
ese parece ser el primer movimiento de KELSEN ${ }^{96}$. Pero inmediatamente advierte que esa solución no resulta satisfactoria. La experiencia indica la presencia de situaciones en las que se mantienen en vigor normas que están en conflicto con otras normas superiores sin que los órganos de aplicación del Derecho se nieguen (e incluso puedan negarse) a aplicarlas invocando el principio lex superior. Éste es, por ejemplo, el caso de las leyes inconstitucionales allí donde no existe un procedimiento para invalidarlas o, si existe ese procedimiento, mientras no hayan sido anuladas. Ése es también el caso de las sentencias firmes dictadas en contra de lo establecido en una ley. En estos casos se diría que estamos ante dos normas jurídicamente válidas pero lógicamente incompatibles. Ésta le parece a KELSEN una situación imposible: «entre una norma de nivel superior y otra de nivel inferior, esto es, entre una norma que determina la producción de otra norma y esta otra norma, no puede existir ningún conflicto, puesto que la norma de nivel inferior tiene su fundamento de validez en la de nivel superior» [RR 212 (217, cursivas mías) ${ }^{97}$. Por eso, con el fin de hacer buena su tesis de la coherencia necesaria del sistema incluso en esos casos, KELSEN lleva a cabo una interesante y significativa maniobra interpretativa. Para empezar señala que, a pesar de la enorme importancia organizatoria que tiene el principio de jerarquía normativa en el sistema jurídico, el conflicto entre una norma inferior $(v . g r$. una ley ordinaria) y otra superior ( $v$. gr. la constitución) no arrastra consigo la nulidad de la norma inferior — como podría inducir a pensar la regla lex superior-, sino más bien su anulabilidad; y, por cierto, eso sólo si el sistema ha previsto procedimientos de anulación para esos $\operatorname{casos}^{98}$. Y a continuación afirma que en caso de conflicto entre normas de diferente rango la norma superior ha de interpretarse de tal modo que i) dote de validez a la norma inferior contraria a ella y al mismo tiempo, y ii) autorice su anulación, si es que hay establecidos procedimientos al efecto. En este sentido, «las llamadas leyes "inconstitucionales" son leyes conformes con la constitución, aunque anulables (aufhebar) siguiendo un procedimiento especial» [RR 278 (280)]. Puede que el sistema no prevea procedimientos de anulación en estos casos $(v \cdot g r$. recursos contra la inconstitucionalidad de las leyes, en el caso de un conflicto de una ley con la constitución), en ese caso eso habrá que interpretar que la norma superior ( $v . g r$. la constitución) autoriza al órgano inferior ( $v$. gr. el Parlamento) a producir cualquier norma, de modo que todo lo que produzca es conforme a la norma superior, incluso si es contrario a ella.

«Si una ley en vigencia puede, en razón de la manera en que ha sido creada o en razón de su contenido, encontrarse en contradicción con la constitución, hay una sola interpretación posible: es necesario admitir que la constitución reconoce no solamente la validez de las leyes constitucionales, sino también, en cierto sentido, la de las leyes denominadas inconstitucionales; de lo contrario no se podría afirmar que dichas leyes están en vigencia. En efecto, la Constitución no se limita a prescribir que las leyes deben ser dictadas siguiendo un procedimiento determinado y tener o no tener tal o cual contenido. Prescribe, además, que las leyes dictadas de otra manera o que tengan un contenido diferente no deben ser consideradas nulas. Por el contrario, son válidas hasta el momento en que sean anuladas

96 De hecho ése es el primer movimiento en PG 296.

97 «Resulta claro que no podría hablarse de la unidad del orden jurídico si el fenómeno de la norma contraria al Derecho importara realmente una contradicción lógica entre una norma superior y una norma inferior. Pero ése no es el caso.» (TP2 156; en términos parecidos TP1 120 y ss.)

98 Algo análogo ocurriría en el caso de la sentencia contraria a la ley. 
por un tribunal o por otro órgano competente de acuerdo con el procedimiento fijado en la Constitución...

La determinación de una norma inferior por una norma superior tiene, pues, un carácter alternativo. El órgano competente para crear la norma superior tiene la posibilidad de optar entre los dos términos de la alternativa, pero el primero le es señalado por la norma superior; y si elige el segundo, la norma por él creada es anulable, aunque permanece válida mientras no haya sido anulada.

Una norma es, pues, válida si ha sido establecida conforme a la norma superior, es decir, de acuerdo con uno o con otro término de la alternativa contenida en esta norma superior. Sólo una norma válida puede ser anulable, y si no lo es, significa que queda definitivamente válida...» (TP 155 y ss.) ${ }^{99}$.

Así, pues, ha de entenderse que la determinación de la norma inferior por la superior contiene tácitamente una cláusula alternativa en el sentido que acabamos de señalar. Sujeta a esa interpretación, resulta que la norma superior faculta a la autoridad inferior a dictar normas incompatibles con ella, de modo que esas normas serán válidas mientras no sean anuladas. La delegación de poder de la autoridad superior en la inferior, tendría, pues, la formulación alternativa «Dicta una norma que sea coherente con las dictadas por mí, o cualquiera otra norma a riesgo de sea anulada». Mediante este hábil juego de prestidigitación KELSEN intenta algo parecido a la cuadratura del círculo: que el respeto a la idea de jerarquía normativa sea compatible con la violación de la jerarquía normativa, que la creación irregular de normas se conforme a Derecho (es decir, no sea irregular), y que no existan conflictos entre normas de distinto rango, incluso cuando lo que prescriben es incompatible.

\section{Eficacia de las reglas}

Como sabemos, KELSEN considera estas cuatro reglas -lex posterior, lex specialis, fusión disyuntiva de las normas y cláusula alternativa tácita- como principios de interpretación no convencionales ${ }^{100}$ : se encuentran implícitos en la norma fundamental, como garante de la unidad lógica del sistema, y por consiguiente forman parte del patrimonio normativo de todo sistema jurídico, incluso si no han sido establecidas por el legislador. Porque, como he señalado, la norma fundamental no se limita a dotar de sentido normativo a los productos de una primera autoridad normativa y a las auto-

99 Vid. de forma más detallada (y también algo más engorrosa), RR 271-280 [273-282].

100 En «On the status of the lex posterior derogating rule» [en R. TuR y W. TwINNING (eds.), Essays on Kelsen, Oxford, Clarendon, 1986], S. PAULSON analiza las vacilaciones de KELSEN a propósito de la naturaleza de la regla lex posterior: en algún pasaje parece verla como un principio de interpretación convencional aunque dado por supuesto por el legislador, en otros parece presentarla como una regla válida a priori, dada la naturaleza dinámica de los sistemas jurídicos. Independientemente de esas vacilaciones, lo cierto es que si están llamadas a asegurar la coherencia como propiedad necesaria del Derecho, no pueden ser consideradas ni como normas positivas ni como principios de interpretación meramente convencionales. Y en este sentido parece expresarse el mismo KELSEN con toda la franqueza deseable. En su primera exploración del tema, KELSEN, comentando la aplicación de la cláusula alternativa tácita, afirma: «Estas interpretaciones no son necesariamente resultado de aplicar cualesquiera reglas de interpretación jurídico-positivas, sino que incluso van contra el tenor literal de preceptos jurídicos positivos». Y un poco más adelante, refiriéndose al procedimiento de «fusión disyuntiva de las normas»: «Esas interpretaciones son reinterpretaciones sin base jurídico-positiva, en contradicción con el tenor literal y el sentido pretendido, es decir, subjetivo, del material jurídico que ha de interpretarse» (PG 296 y ss.). 
ridades delegadas por ella, sino que incluye todo un arsenal de principios no convencionales que tendrían que permitir interpretar el material normativo producido por las autoridades jurídicas de modo que se presente a nuestro conocimiento como un todo dotado de sentido y accesible a una «interpretación racional».

Ahora bien, aun admitiendo la plausibilidad de esta reinterpretación de la norma fundamental, persiste, creo yo la cuestión de si esos cuatro principios realmente aseguran coherencia. Mi opinión es que probablemente cubren todos los casos de antinomia, pero que resulta dudoso que los resuelvan. Los principios lex posterior y lex specialis no plantean, creo yo, mayores dudas: cuando son aplicables, su aplicación disuelve las antinomias. Me parece altamente dudoso, en cambio, que ocurra lo mismo con el principio de fusión disyuntiva de las normas y con el de interpretación de la delegación como una alternativa. Me inclino a pensar que antes que disolver la incompatibilidad, esos dos principios más bien la conservan integrada en el sistema.

Obsérvese que, mientras la aplicación de lex posterior y lex specialis forma parte de una estrategia derogatoria, la aplicación de la fusión disyuntiva de las normas y de la cláusula alternativa tácita forma parte, en cambio, de una estrategia armonizadora: en lugar de anular alguna de las normas implicadas, busca conservar ambas manteniendo sin embargo coherencia. Pero hay que precisar un poco más la forma peculiar como KELSEN ejecuta esta segunda estrategia. La estrategia armonizadora no plantea problemas teóricos cuando opera en el nivel de las disposiciones jurídicas. En ese caso de entre las varias interpretaciones posibles de dos disposiciones de los textos legales el intérprete busca una que proporcione normas coherentes, si es que tal interpretación existe. Naturalmente esa selección tiene que ser razonable y para justificarla habrá que movilizar argumentos interpretativos y probablemente será necesario invocar principios. Pero lo cierto es que si el intérprete tiene éxito, habrá evitado que se forme la antinomia ${ }^{101}$. Así, pues, aplicada a las disposiciones jurídicas, la estrategia armonizadora no es propiamente una estrategia de disolución de antinomias sino más bien de prevención de la formación de antinomias. KELSEN, en cambio, aplica la estrategia armonizadora a normas lógicamente incompatibles; pero al «armonizarlas» ni evita que se forme la antinomia ni la resuelve: simplemente tolera que quede «engastada» en el sistema. Consideremos cada uno de los dos principios por separado

i) El principio de fusión disyuntiva de las normas establece que entre dos normas totalmente contradictorias que se encuentran en el mismo texto legal el juez tiene libertad de elección porque debemos interpretarlas como si estuvieran reunidas en una sola norma que dijera: «En el supuesto s debe ser a o debe ser no a» ${ }^{102}$. Yo creo que ésa es

101 De hecho es así como funciona el Tribunal Constitucional cuando, con el fin de conservar el trabajo legislativo, pronuncia una sentencia interpretativa, seleccionando de entre todas las interpretaciones posibles aquella que no está en conflicto con la Constitución. El mismo Tribunal Constitucional en diversas ocasiones -v. gr. las Sentencias 4/1981, de 2 de febrero [fundamento 1.b)] y 93/1984, de 16 de octubre [fundamento $5 . d)$ ] - declara conceder prioridad a la estrategia armonizadora frente a la derogatoria: «es necesario apurar todas las posibilidades de interpretar los preceptos de conformidad con la Constitución y declarar tan sólo la derogación de aquellos cuya incompatibilidad resulte indudable por ser imposible llevar a cabo dicha interpretación».

102 KELSEN subraya [RR 211 (216)] que en este caso el tenor la proposición jurídica (Rechtssatz) que describe la situación no es «En el sistema jurídico $S$ debe ser a y debe ser no a», sino más bien «En el sistema jurídico $\mathrm{S}$ debe ser a o no debe ser a». Parece pensar que con la sustitución de un enunciado conjuntivo por uno disyuntivo desaparece la antinomia. 
sencillamente una forma de identificar una antinomia, no de resolverla. Al autorizar al juez a aplicar cualquiera de los dos miembros de la disyuntiva, coloca al destinatario en una situación imposible: no puede evitar que, cualquiera que sea su conducta, esté sujeto a poder ser acusado y castigado por haber violado alguna de las normas del sistema. Esa situación se corresponde, punto por punto, con la caracterización que hace KELSEN de antinomia ${ }^{103}$.

ii) Algo parecido ocurre con el principio que exige interpretar la delegación de la autoridad inferior por la superior como si contuviera una cláusula alternativa tácita. Con ayuda de ese principio KELSEN pretende garantizar la ausencia de conflictos entre normas superiores e inferiores, incluso cuando el órgano inferior crea normas incompatibles con las del superior. Pero ese principio no elimina la contradicción, más bien la consagra: después de aplicar el principio interpretativo de KELSEN la norma inferior sigue prescribiendo de forma incompatible (contraria o contradictoria) con la norma superior. Lo único que hace ese principio es establecer una regla de tolerancia dirigida a dotar de validez a las normas eficaces, independientemente de si desde el punto de vista lógico son incompatibles ${ }^{104}$. Que hayamos de interpretar todo acto de delegación de poder normativo como si contuviera necesariamente implícita semejante regla de tolerancia me parece una propuesta altamente discutible de interpretación del acto; en todo caso no elimina, en mi opinión, las contradicciones ${ }^{105}$.

Si bien se mira, al adoptar esta estrategia armonizadora KELSEN entra en conflicto consigo mismo. Él había caracterizado el conflicto de normas como una situación que afectaba negativamente al menos a una de las dos normas implicadas. Recuérdese la formulación de 1960: «dos normas jurídicas se contradicen y, por consiguiente, no pueden ser afirmadas al mismo tiempo como válidas cuando las dos proposiciones jurídicas que las describen se contradicen» [RR 77 (88), cursivas mías]. Y sin embargo, la estrategia armonizadora adoptada por él está diseñada para permitir seguir afirmando ambas normas como válidas. Con ello intenta hacer justicia, por un lado, al carácter di-

103 Recuérdese la definición kelseniana de conflicto de normas: «Existe un conflicto de normas cuando una norma establece como debida una conducta, mientras la otra establece como debida la omisión de esa conducta [...] La situación creada en un conflicto de normas consiste en que si se sigue una de las dos normas en conflicto, se viola la otra...» (ATN 168, en términos parecidos GN 870 y ss.); «un conflicto entre dos normas se da si al obedecer o aplicar una norma la otra es necesaria o posiblemente violada» (D 349). Para ser exactos, hay que admitir que en un cierto sentido el principio de fusión disyuntiva disuelve la antinomia: si (como KELSEN) operamos bajo el muy problemático supuesto de que las normas jurídicas van dirigidas a los jueces y no a los ciudadanos, la aplicación del principio resuelve ciertamente el problema para el juez, pero a costa de dejar al particular en una trampa. (217)].

${ }_{104}$ Pues «la eficacia como condición de validez está establecida en la norma fundamental» [RR 212

${ }_{105}$ KELSEN no interpreta esta estrategia como si estuviera dirigida a resolver una antinomia, sino más bien a evitar que se forme. «El carácter alternativo de la norma superior determinante de la inferior excluye la posibilidad de que la norma inferior aparezca en contradicción lógica efectiva con la superior; pues una contradicción con el primero de los dos preceptos alternativos en que se divide la norma integral de grado superior no es una contradicción con la norma integral alternativamente configurada. Y aún la contradicción de la norma de grado inferior [...] sólo se manifiesta después de ser verificada por la instancia competente [...] La «contradicción» aparece en la esfera del Derecho, pero simultáneamente con la derogación de la norma contradictoria» (TP1 124 y ss., cursivas mías; en términos muy parecido en TP2 160). Es decir, de acuerdo con la estrategia teórica de la cláusula alternativa tácita, antes de la derogación no existe contradicción; pero después de la derogación tampoco, porque el proceso derogatorio la anula. La cuestión obvia que se suscita aquí es por qué se anula una contradicción que no existe. La respuesta de KELSEN es sorprendente: el proceso de derogación en cierto modo pone y anula al mismo tiempo la contradicción. 
námico del Derecho como sistema de normas positivas, afirmando la validez de normas contradictorias por haber sido efectivamente «puestas» por los órganos del sistema, y, por otro, a la idea del sistema como unidad lógica, afirmando que a pesar de todo no son contradictorias; intenta conciliar la eficacia como condición de la existencia de las normas con la coherencia. La estrategia armonizadora seguida por KELSEN revela, pues, hasta qué punto termina siendo confusa su idea acerca de la unidad lógica del Derecho como sistema de normas.

Bien considerado, el examen de las reglas kelsenianas de solución de antinomia indica que con ellas KELSEN no persigue tanto proporcionar recursos normativos para resolver los conflictos entre normas, sino más bien recursos teóricos para permitirnos describir coherentemente un sistema que alberga conflictos. Pero, como veremos a continuación, con ello KELSEN realmente estaba abordando un falso problema.

\subsection{La posición final}

Hemos visto de qué forma KELSEN en la segunda edición de la Reine Rechstlebre — publicada en 1960, cuando el autor tenía 79 años de edad- se creía todavía en condiciones de mantener su tesis de la unidad del sistema jurídico en un sentido particularmente fuerte: el sistema jurídico no sólo es una unidad dinámica, porque sus normas son producidas siguiendo una cadena bien formada de delegaciones de poder, sino también una unidad lógica, porque su contenido sólo puede describirse mediante un sistema de enunciados libre de contradicciones. La norma fundamental tiene que garantizar unidad en ambos sentidos, y para ello incluye como contenido propio un arsenal de principios de interpretación que operan como garantes de la coherencia: dado que tiene la función de construir el Derecho no como una unidad cualquiera sino como una unidad lógica, las reglas de disolución de antinomias forman parte substancial de ella.

Inmediatamente después de la publicación de la segunda edición de la Reine Rechstlebre, completando el giro iniciado en esa obra, KELSEN lleva a cabo un drástico cambio de posición ${ }^{106}$. En esa obra había mantenido la idea del Derecho como una unidad lógica combinando tres tesis: 1) que entre normas no hay conflictos lógicos, de modo que el principio de contradicción no les es aplicable; 2) que, en cambio, las proposiciones jurídicas que describen dos normas antinómicas constituyen una contradicción, lo cual le lleva a admitir, y 3 ) que el principio de contradicción es aplicable indirectamente a las normas, en tanto que objeto de conocimiento. A partir de 1960, KELSEN, reiterando la tesis 1), se desprende enteramente de la tesis 2), lo que obviamente arrastra de forma inmediata el abandono de la tesis 3 ).

Por lo que se refiere a la primera tesis, KELSEN se limita a mantenerse en la posición formulada en la segunda edicición de la reine Rechtslehre, aunque ahora más enérgicamente y al mismo tiempo dentro de un tratamiento algo más cuidadoso del

106 Vid., a este respecto, «Derogation» ya citado, «Law and logic», Philosophical Essays dedicated to Professor Dr. Hermann Dooyend, Amsterdam, North Holland Publ. Co., 1965, y «Recht und Logik», Forum, 142 143 (1965) (ahora en AA.VV., Die Wiener Rechtstheoretische Schule, Europa Verlag, Wien, etc., 1968), así como Allgemeine Theorie der Normen, Wien, 1979, caps. 29 y 57. 
tema relativo al lugar de la lógica en el Derecho ${ }^{107}$. La forma demasiado sumaria como se expresaba en 1960 inducía a pensar que rechazaba la posibilidad de ningún tipo de relación lógica entre normas. KELSEN ahora sustenta una posición algo más diferenciada. No niega que en la esfera de las normas puedan existir relaciones lógicas ${ }^{108}$. Para empezar, la estructura misma de las normas generales, insiste, es de naturaleza lógica, porque la relación que existe en ellas entre condición y consecuencia es una relación lógica, aunque esa relación se formule como «debida» ${ }^{109}$. Y a pesar de negar que entre normas puedan darse relaciones de inferencia, admite que la relación de subsunción de lo particular en lo general que se da entre el supuesto de hecho de la norma general y el caso concreto contenido en la norma individual que se corresponde con ella es de naturaleza lógica, de modo que esa misma relación de correspondencia entre esas dos normas es analizable lógicamente ${ }^{110}$. KELSEN no niega, pues, que la lógica pueda tener algún papel en el Derecho. Lo que tiene interés en subrayar es que las relaciones lógicas que puedan existir entre las normas no tienen efectos sobre la validez de las mismas. Y es eso lo que le lleva a insistir en que no les son aplicables la regla de inferencia y el principio de contradicción.

«Una idea muy extendida entre los juristas es que entre Derecho y lógica [...] existe una relación especialmente estrecha, que una propiedad específica del Derecho es ser lógico; es decir, que las normas jurídicas en sus relaciones recíprocas obedecen a los principios de la lógica. Esto presupone que esos principios - ante todo el principio de contradicción y la regla de la inferencia - son aplicables a las normas en general y a las del Derecho en particular» [RL 1469 (5)]. Ahora bien, «ambos principios lógicos —el de contradicción y el de inferencia - se limitan a fijar en qué condiciones un enunciado - como sentido de un acto de pensamiento- puede ser verdadero y en que condiciones un enunciado así tiene que ser falso. Las normas en cambio estatuyen un deber ser, y puesto que deber ser es un correlato de querer, son el sentido de actos de voluntad, y en cuanto tales no pueden ser ni verdaderas ni falsas [...] Una norma vale o no vale» [RL 1470 ss. (6 ss.)].

La idea de KELSEN es que las normas son el sentido de actos de voluntad, y sólo pueden formar parte del sistema en virtud de actos de voluntad: «No hay imperativo sin imperator, no hay norma sin una autoridad que establezca normas, es decir, no hay norma sin un acto de voluntad del cual ella sea el sentido» (ATN 187; 6). Por eso la regla de la inferencia y el principio de contradicción no pueden aplicarse a las normas. Si fuera aplicable la regla de la inferencia, tendríamos que aceptar que normas que no han sido introducidas mediante actos de voluntad forman parte del sistema simplemente por el hecho de poder «inferirse» de otras: y así, por ejemplo, tendríamos que aceptar que una norma individual inferida a partir de una norma general sería aplicable a un caso, incluso sin haber sido decidida por un tribunal competente. Y si el principio de contradicción fuera aplicable a las normas, entonces una norma creada por el órgano autorizado y siguiendo el procedimiento del sistema dejaría de ser válida, y por consiguiente desaparecería del sistema por el mero hecho de ser incompatible con otra, sin necesidad de un acto de voluntad. En el primer caso sería posible que las normas adquirieran validez sin mediar operaciones de producción normativa, en el segundo

\footnotetext{
107 A ello dedica KeLSEN nada menos los once últimos capítulos de la Allgemeine Theorie der Normen.

108 En resumen, vid. RL 1492 y ss. [32 y ss.] y ATN 216.

109 Vid. ATN, cap. 60.

110 Vid. ATN, cap. 59, II.
} 
sería posible que la perdieran sin mediar operaciones de derogación. Creación y derogación de normas podrían resultar de operaciones del pensamiento, sin mediar actos de voluntad.

Por lo que se refiere en particular al principio de contradicción, KELSEN insiste, como ya había hecho en 1960, en que no es aplicable las normas porque no son susceptibles de verdad o falsedad. Ya conocemos el argumento. El principio de contradicción establece que la conjunción de los enunciados «Es a» y «Es no a» es imposible porque ambos enunciados no pueden ser verdaderos a la vez; necesariamente uno tiene que ser falso. Pero ese principio, como todos los demás principios lógicos, sólo puede regir para enunciados asertóricos, porque sólo ellos son susceptibles de verdad o falsedad. Dado que las normas no son enunciados asertóricos, carece de sentido hablar de contradicciones o conflictos lógicos entre normas. Las normas no son verdaderas ni falsas, sino válidas o inválidas; que una norma sea válida significa que existe como norma, pero no que sea verdad.

Desde siempre KELSEN había mantenido clara la distinción entre enunciados asertóricos o descriptivos y normas: los primeros son el sentido de actos de pensamiento, las segundas el sentido de actos de voluntad; los primeros pueden ser verdaderos o falsos, las segundas válidas o inválidas. Con todo, si durante la mayor parte de su vida pudo afirmar la tesis de la aplicabilidad del principio de contradicción a las normas era porque establecía una analogía entre verdad y validez, que ahora cree basada en un serio malentendido. Recuérdese una de sus primeras incursiones en el tema: «El principio de contradicción rige [...] tanto para la esfera del ser como para la del deber ser; pues los dos juicios «debe ser a» $\mathrm{y}$ «no debe ser a» son tan incompatibles como los dos juicios «es a»y «no es a». Si el material jurídico que se presenta al conocimiento muestra una contradicción de este tipo, que anula todo sentido, si los actos jurídicos aparecen con un sentido subjetivo de ese tipo, esa contradicción, si se trata de normas de uno y el mismo sistema, tiene que encontrar una solución, es decir, el sentido subjetivo contradictorio no puede convertirse en sentido objetivo» (PG 295 y ss.)». Del mismo modo que dos enunciados asertóricos contradictorios no pueden ser ambos verdaderos, dos enunciados normativos contradictorios no pueden ser ambos válidos; y como la validez es la forma de existencia de las normas, ambos no pueden transformarse en normas capaces de coexistir en el mismo sistema normativo.

En sus últimos escritos KeLSEN se afana por desmontar esa analogía ${ }^{111}$. Por una parte, en el caso de los enunciados asertóricos la verdad es una propiedad contingente del enunciado; en el caso de las normas la validez es, en cambio, su propia existencia específica ${ }^{112}$. Un enunciado existe con independencia de si es verdadero o falso; una norma, en cambio, no puede no ser válida: una norma inválida es una no-norma: «una norma válida es un pleonasmo, una norma inválida una contradictio in adjecto» (ATN 137). Por otra parte, la contradicción entre enunciados es un fenómeno enteramente diferente del conflicto de normas; la contradicción tiene que ver con las con-

111 Vid. ATN 44.

112 «La verdad y la falsedad son propiedades de un enunciado, mientras que la validez no es propiedad de una norma sino su existencia, su existencia específica, ideal» [RL 1472 (9)]. 
diciones de verdad entre enunciados relacionados formando un sistema; el conflicto entre normas presupone, en cambio, la validez de las dos normas implicadas: «es imposible que dos enunciados contradictorios sean ambos verdaderos; es posible ${ }^{113}$, en cambio, que dos normas en conflicto sean ambas válidas» [RL 1478 (16)].

Naturalmente, al rechazar la aplicación del principio de contradicción a las normas KELSEN no niega el fenómeno que denominamos «antinomias», es decir, que puedan presentarse conflictos entre normas que prescriben conductas incompatibles. Lo que está en juego es la naturaleza del fenómeno: las antinomias no son conflictos lógicos, y no representan una forma de contradicción. Más aún —añade KELSEN con astucia - sólo tiene sentido hablar de conflictos entre normas si admitimos que esos conflictos no son contradicciones lógicas. Pues la consecuencia que deberíamos extraer de la presencia de una contradicción entre normas, si es que algo así existiera, es la inexistencia de una de las dos normas implicadas, y por consiguiente la imposibilidad del conflicto. El argumento de KELSEN es sencillo. Si admitiéramos la analogía entre la verdad de los enunciados asertóricos y la validez de las normas, tendríamos que aceptar que, igual que dos enunciados contradictorios no pueden ser ambos verdaderos, dos normas lógicamente contradictorias no pueden ser ambas válidas; y como la validez es el modo de existencia de las normas, ambas no podrían existir como parte del sistema jurídico. En esas condiciones no cabría entre ellas un conflicto, porque el conflicto entre normas presupone la existencia de las dos normas en conflicto ${ }^{114}$. Una antinomia es un conflicto entre normas precisamente si no es una contradicción, es decir, si no es un conflicto lógico. Los conflictos entre normas se dan entre dos normas que son ambas válidas. Pero no pueden considerarse conflictos lógicos, es decir, contradicciones.

«No cabe duda de que semejantes conflictos de normas existen [...] Un conflicto de normas presupone que las dos normas en conflicto son válidas. Los enunciados que afectan a la validez de las dos normas son verdaderos. Por eso [...] un conflicto de normas no es una contradicción, ni nada que pueda compararse con una contradicción lógica. Mediante derogación se cancela la validez de una norma válida. En el caso de una contradicción lógica entre dos enunciados, uno de los dos enunciados es desde el principio falso. Su verdad no es cancelada, pues no existe desde el principio. Puesto que la validez de una norma es su específica existencia, un conflicto de normas [...] no puede compararse con una contradicción lógica, sino sólo con dos fuerzas que operan sobre un mismo punto, pero en direcciones opues-

113 En realidad no sólo es posible sino que también es necesario, ya que, como veremos inmediatamente, para que dos normas entren en conflicto, ambas tienen que existir, es decir, ser válidas y pertenecer al mismo sistema.

114 «Un enunciado es verdadero o falso. Una norma, en cambio, no es ni verdadera ni falsa, sino que vale o no vale. Y entre la verdad de un enunciado y la validez de una norma no existe paralelismo o analogía alguna. Subrayo esto enfrentándome conscientemente a una opinión generalmente aceptada, y que yo mismo también be defendido durante mucho tiempo [!]. Si existiera una analogía o paralelismo entre la verdad de un enunciado y la validez de una norma, el principio de contradicción, que encuentra aplicación a dos enunciados en conflicto, tendría que poder aplicarse también per analogiam a dos normas en conflicto. Así como de dos enunciados en conflicto sólo uno puede ser válido, y el otro inválido, de dos normas en conflicto sólo una podría valer mientras que la otra tendría que ser inválida. Pero no es ése el caso. Pues si fuera verdad que de dos normas, una de las cuales prescribe una conducta, mientras que la otra prescribe la omisión de esa conducta, sólo una de ellas puede valer, no podría darse un conflicto entre normas. Cuando de dos normas sólo vale una, no hay dos normas, sino sólo una, y por consiguiente no hay conflicto alguno. Pues la validez de una norma es su existencia específica e ideal, su presencia (ihr Vorbandensein); y una norma que no vale, no existe, no es una norma» [GN 870 y ss.; también RL 1482 y ss. (21 y ss.)]. 
tas $^{115}$. Un conflicto de normas es un caso posible y nada raro» (ATN 100 y ss., cursivas mías) ${ }^{116}$.

Al establecer la analogía con un campo de fuerzas, KELSEN parece pensar que una antinomia no es un conflicto lógico sino más bien un conflicto teleológico: es la consecuencia de que el legislador persigue dos fines incompatibles de modo que su voluntad se proyecta sobre la conducta de los destinatarios de las normas dirigiéndolos en direcciones opuestas. Naturalmente la existencia de conflictos entre normas representa una seria deficiencia del sistema, porque prescribe conductas incompatibles: el seguimiento de una norma implica la violación de otras, de modo que no es posible no violar alguna norma del sistema. Ahora bien, un sistema normativo incoherente es deficiente, pero no es un absurdo lógico.

Hasta aquí KELSEN, como se ve, no hace sino proseguir —ahora sin concesionesuna línea de pensamiento que ya había iniciado en la segunda edición de la Reine Rechtslebre. Ahora bien como sabemos, en esa obra todavía intentaba salvar la idea de la unidad lógica o coherencia del sistema jurídico: aun admitiendo que no puede hablarse propiamente de contradicciones entre normas, todavía podrían interpretarse los conflictos entre normas (que es la forma como KELSEN designa las antinomias) como violación del principio lógico de contradicción en un sentido indirecto, a saber, a través de los enunciados metalingüísticos (Rechssätze) que informan sobre las normas (Rechtsnormen). Por esa vía indirecta podrían todavía entenderse las reglas de resolución de antinomias como reglas no convencionales, de naturaleza lógica. Podemos resumir el razonamiento de KELSEN en 1960 en los siguientes términos: i) quien se proponga describir un sistema jurídico en el que existan normas incompatibles tendrá que hacerlo mediante enunciados del tipo «En el sistema jurídico $S$ debe ser $a$, y debe ser no $a \gg$; ahora bien, ii) como cualquier enunciado asertórico, también ése está sujeto a exigencias lógicas, pero iii) dado que ese enunciado es la conjunción de dos enunciados asertóricos con contenido contradictorio, hemos de aceptar que nos encontramos ante una contradicción en sentido propio; y iv) puesto que una contradicción es un sinsentido, la ciencia jurídica sólo podrá describir el sistema jurídico como un todo cargado de sentido si elimina los conflictos, recurriendo a reglas como las que conocemos, incluso si esas reglas no han sido establecidas positivamente; v) dado que la norma fundamental tiene que permitirnos pensar el sistema jurídico como un todo con sentido, las reglas de solución de antinomias han de pensarse como formando parte de la norma fundamental; finalmente, y (vi) las reglas de solución de antinomias operan en el plano (metaligüístico) de la ciencia jurídica, pero al mismo tiempo forman parte de la norma fundamental, y dado que la norma fundamental es el fundamento de la validez las normas jurídicas y el criterio último de su pertenencia al sistema, produce coherencia en el sistema, al configurar su propio objeto como accesible al conocimiento jurídico.

115 En RL 1479 [16] a esa última frase añade KELSEN: «Las dos situaciones, un conflicto entre normas y un conflicto entre fuerzas, pueden describirse sin incurrir en ninguna contradicción». Es significativo que KELSEN aplique ahora al caso de conflictos entre normas pertenecientes al mismo sistema una analogía de la incidencia de fuerzas contrarias sobre el mismo cuerpo que inicialmente había aplicado al conflicto que se da entre normas que pertenecen a diferentes sistemas, $v$. gr. normas jurídicas y morales (vid. PG 303, NPR 75).

116 En términos similares D 351. En realidad podríamos decir que si el principio de contradicción fuera aplicable a las normas el sistema jurídico sería necesariamente coherente; las antinomias serían conflictos entre normas sólo presuntas, pero no entre normas realmente existentes. 
Ésta era la argumentación que seguía KELSEN todavía en 1960. En sus últimos escritos la considera enteramente errónea. Y con razón. El paso iii) en la cadena argumental descansa en un serio malentendido. Un enunciado asertórico del tipo «Es $a$ y no es $a$ » es un sinsentido: afirmar «En este momento está lloviendo y no está lloviendo» es la conjunción de dos enunciados uno de los cuales necesariamente es falso. Lo mismo vale para las proposiciones jurídicas que informan sobre la validez de una norma: «Los dos enunciados En el ordenamiento jurídico O vale la norma "El adulterio debe ser castigado" y En el ordenamiento jurídico O no vale la norma "El adulterio debe ser castigado" se encuentran en contradicción lógica; sólo uno u otro puede ser valido» [RL 1491 (31)]. El principio de contradicción es, pues, aplicable también a las proposiciones jurídicas, como enunciados asertóricos que son, susceptibles de ser problematizados desde el punto de vista de la verdad; y lo cierto es que no puede ser verdad que en el sistema jurídico $\mathrm{S}$ esté vigente la norma $\mathrm{N}$ y no lo esté. Ahora bien, cuando nos encontramos ante un conflicto de normas, estamos ante dos normas jurídicas que han sido creadas por órganos competentes siguiendo los procedimientos previstos y que, por consiguiente, desde el punto de vista sistemático son ambas válidas al mismo tiempo - precisamente se presenta conflicto porque ambas normas son válidas-. Pero dos normas válidas son dos normas que existen y forman parte del sistema. Por eso, aunque la existencia de conflictos entre normas es indeseable, los enunciados asertóricos (Rechtssätze) mediante los que informamos de la existencia de normas incompatibles en un sistema jurídico no constituyen ni una contradicción ni un sinsentido: simplemente suministran información (verdadera) sobre un hecho relativo a un sistema jurídico determinado — aunque deficiente—. Afirmar «En el sistema jurídico S hay una norma que prescribe a y otra que prescribe no a», no sólo no es incurrir en un sinsentido sino que puede ser emitir un enunciado verdadero; y lo será si, en efecto, las dos normas en conflicto han sido creadas por la autoridad competente siguiendo el procedimiento previsto, y son válidas.

«Hay que distinguir [...] entre una norma y el enunciado sobre la norma, es decir, el enunciado sobre la validez de la norma. Los enunciados sobre la validez de las normas son, como todos los enunciados, verdaderos o falsos. El enunciado sobre la validez de una norma es verdadero cuando la norma vale [...] Puesto que los enunciados sobre la validez de las normas pueden ser verdaderos o falsos, los principios de la lógica son aplicables a los enunciados sobre la validez de las normas». Ahora bien, «dado que dos normas que se encuentran en conflicto pueden valer ambas - de lo contrario no habría un conflicto de normas- los enunciados sobre la validez de ambas normas no representan una contradicción lógica, incluso si una de las normas establece como debida una conducta mientras que la otra establece como debida la omisión de esa misma conducta»... «De lo dicho se desprende que entre enunciados sobre la validez de dos normas en conflicto no existe ninguna contradicción lógica, como tampoco la hay entre las dos normas en conflicto "El divorcio debe ser castigado"/"El divorcio no debe ser castigado". Las dos normas establecen como debida una conducta — la una un "ser castigado", la otra un "no ser castigado"- - Las dos normas pueden ser válidas, una al lado de la otra [...] Por eso, dos enunciados, uno de los cuales afirma la validez de una de esas dos normas válidas y el otro la validez de la otra son ambos verdaderos y no representan ninguna contradicción lógica» (ATN 177 y ss.)

El error de la posición defendida por KELSEN en 1960 derivaba de no haberse percatado de que, dado el carácter metalingüístico de las proposiciones jurídicas (Rechtssätze) que nos informan sobre la existencia de normas jurídicas incompatibles, en 
ellas la contradicción aparece citada, no afirmada — aparece mencionada, no usada-. Y mencionar una contradicción no es incurrir en ella. Afirmar: «En el sistema jurídico $S$ debe ser a y debe ser no a» no es una contradicción, sino emitir un enunciado (metalingüístico) a propósito de un sistema jurídico, un enunciado que puede ser verdadero - si realmente existen las dos normas correspondientes-. Esto es algo que rige en general para los enunciados asertóricos de carácter metalingüístico, tanto si se refieren a normas como si se refieren a otros enunciados asertóricos. Si en un momento dado afirmo «Ahora está lloviendo y no está lloviendo» incurro en contradicción. Pero si a continuación alguno de mis oyentes emite el enunciado (metalingüístico) «Rodilla ha afirmado que ahora está lloviendo y no está lloviendo», no solamente no cae en contradicción alguna, ni está incurriendo en ningún absurdo, sino que está diciendo sencillamente la verdad. En el caso del Derecho, si admitimos que una norma que prescribe a y otra que prescribe no a pueden ser ambas válidas, entonces el enunciado (metalingüístico) «En el sistema jurídico $S$ hay una norma que prescribe a y otra que prescribe no a» no es una contradicción; puede que sea un enunciado verdadero. Por consiguiente tampoco de forma indirecta es aplicable el principio de contradicción a las normas ${ }^{117}$.

Ahora bien, la tesis de que: 1) los conflictos entre normas no son contradicciones lógicas, unida a la de que 2) afirmar la validez de dos normas incompatibles no es incurrir en un absurdo desde el punto de vista lógico, conduce a KELSEN a liquidar su concepción inicial: i) sobre el sentido que tiene la idea de coherencia en el Derecho, ii) sobre el contenido y función de la norma fundamental, y de paso, iii) sobre la naturaleza y el status sistemático de las reglas que permiten resolver las antinomias (o, en la terminología kelseniana, los conflictos entre normas) —haciendo con ello desaparecer todo rastro de la idea del sistema jurídico como «unidad lógica».

i) Para empezar, la coherencia no forma parte de la validez de las normas jurídicas; en un sistema jurídico las normas entran y son expulsadas del sistema en virtud de actos de producción normativa. Puede que la coherencia sea un objetivo deseable, y seguramente lo es, pero no es una propiedad necesaria del sistema jurídico; más bien es una propiedad improbable. Un sistema jurídico incoherente es un sistema normativo deficiente, desde el punto de vista práctico, pero no es un absurdo desde el punto de vista lógico. Debemos esforzarnos por evitar los conflictos entre normas, pero hemos de reconocer que, como sistema dinámico, el Derecho es propenso a generar normas incompatibles. En todo caso las normas jurídicas integran una unidad dinámica, no una unidad lógica

ii) Dentro del pensamiento tardío de KelSEN la norma fundamental sigue teniendo, ciertamente, la función de permitirnos considerar como una unidad dotada de sentido normativo lo que de otro modo no sería más que un conjunto de actos de voluntad, pero ya no como una unidad dotada de sentido lógico. Los productos de los actos de voluntad de ciertas personas - que ocupan posición de autoridad como jueces, legisladores, etc.- , son normas en la medida en que todos ellos puedan remitirse, siguiendo cadenas de validez bien formadas, a la norma fundamental. La norma fundamental nos permite, pues, interpretar ciertos actos como productores de normas

117 RL 1492 [32], rectificando explícitamente la posición mantenida en la 2. ed. de la Reine Rechtslebre. 
y ciertos enunciados prescriptivos como normas válidas. Pero para ello no necesita asegurar coherencia, es decir, ausencia de conflictos entre las normas. En este sentido el KELSEN tardío descarga a la norma fundamental de la función de garante de la coherencia. La norma fundamental puede ser, pues, la base un sistema jurídico incoherente: se limita a dotar de autoridad a un órgano de creación de normas, cuyos actos de voluntad pueden producir normas incoherentes. Ninguna regla lógica puede protegernos frente a ese riesgo.

iii) En esas condiciones un sistema sólo puede lograr coherencia en la medida en que disponga de reglas para resolver los conflictos entre normas, y en la medida en que esas reglas sean efectivas. Pero esas reglas sólo pueden existir en la forma de normas positivas ${ }^{118}$ : «Un principio así, capaz de resolver el conflicto, puede — pero no tiene que- estar estatuido por una norma positiva. Si no está estatuido, el conflicto sigue sin resolver» (ATN 169). La forma más común de resolver un conflicto de normas es la derogación —anular alguna de las normas en conflicto- . Ahora bien, la anulación de una norma no es simplemente función de las dos normas en conflicto, como ocurriría si la validez de las normas dependiera de sus relaciones lógicas: requiere disposiciones derogatorias ${ }^{119}$. Como forma de resolver un conflicto de normas, «la derogación tiene lugar cuando la autoridad que establece la norma la estatuye» (ATN 101; D 351), «no es un principio lógico, sino la función de una norma jurídica positiva», por lo cual «no tiene que entrar en aplicación de forma necesaria, sino que sólo puede aplicarse si ha sido estipulado positivamente» [D 354; ATN 102; vid. también RL 1479 y ss. (18)]. Si la operación de privar de validez a una norma válida no es una operación lógica, sino una operación de aplicación de una norma de Derecho positivo, entonces no incumbe a la ciencia jurídica — como todavía pensaba KELSEN en 1960—, sino a los órganos encargados de aplicar el Derecho. El científico del Derecho puede (y debe) señalar que existe el conflicto, pero la solución del conflicto no es de su competencia:

«Lo que interesa a la teoría del Derecho es que los principios de derogación no son principios lógicos y que si no están establecidos expresamente o presupuestos como tácitamente establecidos, los conflictos entre normas permanecen sin solución, y que la ciencia del Derecho es tan poco competente para resolver los conflictos existentes entre normas $-v$. gr. por medio de la interpretación-, es decir, cancelar la vigencia de normas establecidas, como para poner normas en vigor» (ATN 103) ${ }^{120}$.

El resultado de todo ello es, pues, que las reglas de disolución de antinomias no son principios lógicos, universalmente válidos, aplicables en todo caso e independientemente de la voluntad del legislador, porque están implícitos en la norma fundamental y por consiguiente forman parte de todo sistema jurídico, sino que en el mejor de los

118 Vid. ATN cap. 57, IV.

119 «La comprensión de la esencia de la derogación se ha visto enturbiada por la doctrina adoptada por la jurisprudencia romana formulada en la frase lex posterior derogat priori. Esta frase es desorientadora. Ante todo porque despierta la impresión de que la derogación es función de una de las dos normas en conflicto. Lo cual es [...] erróneo. La frase en cuestión es problemática también porque, dado que la derogación no es un principio lógico, sino un principio jurídico-positivo, no tiene que entrar en aplicación necesariamente, sino sólo cuando está jurídico-positivamente normado, y porque de ningún modo entra en aplicación en todos los casos de conflicto de normas» (ATN 102; en términos parecidos, D 354; cursivas mías). «La anulación de la validez de una de las dos normas o de ambas sólo puede producirse en el procedimiento de producción de normas, especialmente mediante una norma derogatoria» (ATN 168).

120 En los mismos términos, D 355. 
casos son normas positivas en aquellos sistemas que efectivamente las hayan acogido, y en la medida en que lo hayan hecho.

A esta concepción tardía de KELSEN se podría objetar que hay ciertas reglas de disolución de antinomias - precisamente las conocidas tradicionales reglas lex posterior, lex superior, lex specialis - cuya aplicación por los juristas, y en particular por los jueces, se constata incluso en sistemas jurídicos en los que no se encuentran consagrada explícitamente como normas positivas. La respuesta de KELSEN a esta objeción es que las normas pueden ser positivas de dos modos: por haber sido creadas explícitamente por el legislador o por haber sido «presupuestas tácitamente como obvias» (selbstverständlich, stillschweigend vorausgesetzt) por el legislador ${ }^{121}$. Precisamente este segundo sería el caso de la aplicación de reglas de solución de antinomias cuando no han sido establecidas explícitamente por el legislador. Lo malo de esta respuesta no es sólo que tenga la apariencia incómoda de una respuesta demasiado ad boc, sino que abre la puerta para introducir bajo el rótulo «Derecho positivo» cualquier cosa que nos pueda parecer conveniente.

La posición final de KELSEN sobre el status de las reglas de disolución de antinomias se resume en el siguiente comentario sobre la regla lex posterior:

«La frase en cuestión [lex posterior derogat priori] es problemática también porque, dado que la derogación [de normas en conflicto] no es un principio lógico, sino un principio jurídico-positivo, no tiene que entrar en aplicación necesariamente, sino sólo cuando está jurídico-positivamente normado, y porque de ningún modo entra en aplicación en todos los casos de conflicto de normas...

Contra la afirmación de que la derogación que resuelve un conflicto entre normas, y especialmente el principio lex posterior derogat priori, no es un principio lógico sino un principio jurídico-positivo podría objetarse que una norma que regule la derogación en caso de conflicto entre normas, en la mayor parte de los casos no se encuentra como norma expresamente establecida en un orden jurídico positivo. Esto se explica por el hecho de que el legislador se abstiene de normar expresamente algunas cosas porque las presupone tácitamente como obvias. Es posible que los tres modos de resolver conflictos entre normas se apliquen tan comúnmente como principios de interpretación por los órganos de aplicación del Derecho, que su vigencia se considere obvia —también por los legisladores—» (ATN 102 y ss.) $)^{122}$.

Después de ello, la idea Derecho como una unidad lógica se ha evaporado enteramente.

\section{Excurso II. Lo que queda de las reglas para la disolución de las antinomias}

Corrigiendo la frase anterior, tal vez debería decir que en el último KELSEN la idea del Derecho como unidad lógica casi se ha evaporado por completo. Un examen de las reglas para la solución de los conflictos entre normas saca a la luz un indicio significativo de lo difícil que le resultaba a KELSEN desprenderse de una idea que tan temprano había arraigado en él.

121 «...una norma que el legislador considera obvia y por eso no la formula expresamente, sino que la presupone tácitamente también es una norma puesta, una norma positiva» [RL, 1480 (19)].

122 En términos parecidos, D 354 y ss. y RL 1479 y ss. (17 y ss.). 
En la parte final de Derogation y en el cap. 29 de la Allgemeine Theorie der Normen KELSEN hace una incursión en las estrategias que puede adoptar un orden jurídico para resolver los conflictos entre normas. El examen es menos completo y menos compacto de lo que fue el estudio de las reglas para la disolución de antinomias en «Die philosophischen Grundlagen der Naturrechtslehre...» (1928) y en la segunda edición de la Reine Rechtslebre (1960). De hecho, ahora KELSEN contempla sólo con algún detalle dos casos de conflicto: i) entre normas distanciadas en el tiempo, y ii) entre normas de diverso grado dentro de la jerarquía normativa ${ }^{123}$. No es sorprendente que el tratamiento del tema sea ahora más ligero, si se tiene en cuenta su convicción final de que la solución de las antinomias depende contingentemente de estrategias normativas adoptadas positivamente por el legislador —en ese sentido la solución de las antinomias no es algo que la teoría misma pueda predeterminar por sí sola-. Justamente por eso resulta sorprendente la distinta naturaleza de la respuesta que da a esos dos casos de conflicto.

i) Como acabamos de ver, KELSEN plantea el caso del conflicto entre normas distanciadas en el tiempo para acentuar el carácter positivo y contingente del tradicional principio lex posterior: ese principio está en condiciones de resolver un conflicto de normas sólo si ha sido establecido positivamente por el legislador o, si no lo ha sido, ha sido dado por sobreentendido. El principio lex posterior es, pues, convencional y en este caso la disolución del conflicto depende contingentemente de la existencia de una norma positiva que lo imponga ${ }^{124}$.

ii) En el caso de un conflicto entre una norma superior y otra inferior $(v \cdot g r$. el caso de una ley «inconstitucional») KELSEN, en cambio, insiste en que, bien mirado, no hay tal conflicto. Y para ello recurre a la estrategia que ya conocemos de interpretar que la norma superior contiene una cláusula tácita otorgando al órgano inferior la alternativa de crear una norma conforme con la superior o cualquier otra norma, a riesgo de que sea anulada:

«La constitución de un Estado puede determinar que el legislador debe tratar por igual a los hombres independientemente de su religión o de su raza, pero puede que más tarde el legislador promulgue una ley en la que se impongan determinadas obligaciones o se concedan determinados derechos sólo a hombres pertenecientes a una determinada religión o raza. Entonces puede que [...] la norma anterior (superior) pierda su validez. En este caso, que es el caso de una norma inconstitucional, hay sin embargo que tener en cuenta que de acuerdo con el Derecho positivo la ley denominada «inconstitucional» puede ser válida, pero que su validez puede ser anulada mediante un procedimiento especial previsto por la constitución, $v$. gr. mediante la decisión de un tribunal especial. Luego no existe conflicto alguno entre normas. Pues cuando la norma en cuestión es válida, es también acorde con la constitución, es decir, la constitución autoriza al legislador también a la promulgación de la

123 A decir verdad, KELSEN todavía menciona incidentalmente el caso de conflicto (total) entre dos normas emitidas por el mismo órgano en el mismo texto legal. Pero lo hace para despacharlo, como era de esperar, mediante una fórmula que en realidad equivale a decir que no hay ninguna solución predeterminada, que la solución queda enteramente en manos del legislador: «Una y la misma ley del legislador puede contener dos normas en conflicto. En ese caso, si no es válida la norma de que el órgano de aplicación del Derecho puede elegir aplicar una u otra, puede serlo la norma de que las dos normas que han entrado en vigor pierden su validez» (ATN 102; también D 1440 y ss.).

${ }^{124}$ Lo mismo dice, de forma enteramente incidental, a propósito del principio lex specialis: «no es aplicable mientras no haya sido establecido expresa o tácitamente por la autoridad jurídica» (ATN 267, n. 83). 
ley en cuestión y prevé sólo la posibilidad de anular esa ley en un procedimiento especial» (ATN 101 y ss.; D 1440, cursivas mías).

Obsérvese que, a diferencia de lo que hace con lex posterior, KeLSEN mantiene la vieja estrategia de la cláusula alternativa tácita entendida como un principio interpretativo de carácter no positivo ${ }^{125}$, y ello para reafirmar aquella vieja tesis de que «entre una norma de nivel superior y otra de nivel inferior, esto es, entre una norma que determina la producción de otra norma y esta otra norma, no puede existir ningún conflicto, puesto que la norma de nivel inferior tiene su fundamento de validez en la de nivel superior» [RR 212 (217)]. Se percibe aquí, creo yo, una resistencia a admitir que pueda existir un conflicto entre normas de distinto rango, incluso en un momento en que KELSEN ha abandonado enteramente la idea de la unidad lógica del Derecho como sistema normativo, cuando por consiguiente no hay ninguna razón para que niegue la posibilidad de que se den conflictos entre normas de distinto rango. En esa resistencia, que parece estar muy profundamente arraigada en él, veo yo un síntoma de una dificultad para desembarazarse enteramente de la idea del Derecho como un sistema normativo coherente.

\section{ESBOZO DE UN DIAGNÓSTICO}

Creo que en las oscilaciones de opinión que experimenta KELSEN en relación con el tema de los conflictos entre normas y la coherencia del sistema jurídico se revela una tensión subterránea que atraviesa de punta a cabo la teoría pura del Derecho: la tensión existente entre una concepción positivista de la ciencia del Derecho y una visión constructivista del conocimiento jurídico. Y creo que en esa tensión se refleja una peculiaridad de la teoría del Derecho kelseniana: una teoría positivista elaborada en la estela del neokantismo.

A la hora de exponer la concepción kelseniana del Derecho como un sistema de normas a menudo no se llama suficientemente la atención, creo yo, sobre un hecho que desde el punto de vista filosófico es de gran significación: KELSEN no concibe el sistema jurídico como un dato para el conocimiento sino como un constructo del conocimiento - como una construcción de la ciencia jurídica-. Y en ello se revela una herencia neokantiana que en ningún otro punto se hace más evidente que en la doctrina a propósito de la norma fundamental. KELSEN caracteriza las normas jurídicas como el sentido de actos de voluntad, de modo que un acto de producción normativa es condición necesaria de su existencia: «no hay imperativo sin imperator, no hay norma sin una autoridad que establezca normas, es decir, no hay norma sin un acto de voluntad del cual ella sea el sentido». Pero insiste en que un conjunto de actos de voluntad sólo ad-

125 Con perspicacia J. Ruiz MANERo llama la atención sobre el diferente efecto que KeLSEN atribuye ahora a las normas positivas que incorporan los principios tradicionales lex posterior y lex superior. La norma positiva que establece que en caso de conflicto entre una norma anterior y otra posterior prevalece esta última es «una norma derogatoria directa, que priva por sí misma de su validez a la norma anterior incompatible con otra posterior». Un ordenamiento jurídico puede también contener una norma positiva que incorpore el principio lex superior; pero a diferencia del caso anterior, esa norma no es propiamente una norma derogatoria: «no deroga directamente a la norma de grado inferior incompatible con otra anterior, sino que se limita a habilitar a un órgano de control para que prive de su validez (para que derogue) a la norma posterior de grado inferior» (Jurisdicción y normas, op. cit., pp. 75 y ss.). 
quiere carácter jurídico en la medida en que podamos interpretarlos en último término bajo la suposición de la norma fundamental. Es la suposición de la norma fundamental lo que nos permite contemplarlos como actos jurídicos, esto es, por un lado, como productores de normas, fuentes de derechos y obligaciones, y, por otro, como sujetos a normas, como actos accesibles, por tanto, a un estudio normativo, en lugar de como meros fenómenos psicológicos o sociológicos objeto de investigación empírica. Como sabemos, KELSEN atribuye a la norma fundamental la naturaleza de una hipótesis o una suposición, porque asumirla es adoptar una perspectiva que podemos o no desear adoptar para la interpretación de los fenómenos. Los mismos hechos sociales que interpretamos desde un punto de vista normativo, como hechos generadores de deberes, derechos, obligaciones, normas, etc., pueden ser objeto de un examen empírico, en términos de intereses, decisiones y relaciones de fuerza, en suma, en términos de relaciones causales. Pero si queremos hacerlos accesibles a un análisis jurídico, y no, por ejemplo, sociológico, tenemos que contemplarlos en términos normativos. Y para ello hemos de suponer la norma fundamental. La norma fundamental es así el presupuesto del conocimiento jurídico y de la interpretación jurídica de los fenómenos.

Ahora bien, por más que por detrás de ella KELSEN se empeñe en situar una voluntad (supuesta o ficticia), la norma fundamental no es una norma positiva, fruto de un acto de voluntad, sino más bien un producto del intelecto - algo que pone el conocimiento jurídico para poder aprehender su objeto-. En este sentido el sistema jurídico no es algo que venga dado al conocimiento jurídico, sino un objeto construido por el conocimiento. Ahora bien, desde el momento en que el conocimiento jurídico construye su propio objeto, lo somete a sus propias exigencias.

Este punto de vista, característicamente neokantiano explica, creo yo, que durante mucho tiempo KELSEN tendiera de forma espontánea a trasladar al Derecho ciertas exigencias que parece casi natural que deseemos imponer a un sistema normativo construido racionalmente. El Derecho, parece pensar KELSEN, no es cualquier conjunto de normas producidas por decisiones humanas, sino un conjunto de normas que ha de poder concebirse como una construcción racional - por supuesto, no como un sistema de normas justas, pero sí como un sistema que, por ejemplo, no contenga directivas de conducta contradictorias y esté en condiciones de proporcionar una solución a cada caso que se produzca dentro de su universo-, un sistema, en suma, libre de antinomias y de lagunas. Pero, puesto que coherencia y compleción no son propiedades necesariamente vinculadas a los productos de una legislación humana, han de ser logradas en el curso de una labor de interpretación reconstructiva a partir del material suministrado por el legislador. Visto desde este punto de vista, el conocimiento jurídico tiene un papel activo: no se limita a registrar el material jurídico, sino que lo configura como una construcción que es capaz de satisfacer ciertas exigencias de racionalidad deseables en un sistema normativo — de forma muy destacada, la exigencia de coherencia y la exigencia de compleción-. Como ya sabemos, KELSEN permanece fiel a esta visión casi hasta el final de su vida: como sistema, el Derecho no es sólo una unidad dinámica sino además una unidad lógica.

$\mathrm{Al}$ afirmar la tesis de la unidad lógica del Derecho como sistema de normas KELSEN sigue atribuyendo al conocimiento funciones relevantes en relación con la integración del sistema. Y eso revela que, a pesar de los esfuerzos de toda su vida por distanciarse 
críticamente de la concepción de la ciencia jurídica característica de la dogmática alemana tradicional, mantiene un hilo de conexión con la visión tradicional del sistema como una construcción científico-jurídica. Pero lo cierto es que esa tesis parecía chocar con la pretensión de neutralidad del conocimiento, característica del positivismo y con la exigencia de no confundir el Derecho que es con el Derecho que debe ser. Y además parecía forzar al teórico del Derecho a introducir en el sistema jurídico ingredientes que no son propiamente positivos, que no son simplemente resultado de actos de voluntad. Por otra parte, esta visión del Derecho como un objeto construido por la ciencia jurídica —en la que el enfoque neokantiano encontraba inesperadamente un cierto punto de contacto con el enfoque de la dogmática jurídica tradicionalchocaba también con la tesis kelseniana sobre el carácter meramente descriptivo de la ciencia del Derecho. Uno de los temas recurrentes en KELSEN es la refutación del carácter práctico atribuido por la teoría del Derecho tradicional a la ciencia jurídica: la ciencia jurídica, sostiene él, no es una ciencia práctica —entre otras cosas porque en su opinión la expresión «ciencia práctica» es absurda, una contradictio in adjecto- ${ }^{126}$, sino una empresa teórica cuyo cometido fundamental es describir el Derecho positivo de un país. Esta concepción descriptivista de la ciencia jurídica, sin embargo, tiene que someterse a revisión desde el momento en que se concibe el sistema jurídico como «un todo pleno de sentido», como un constructo racional elaborado mediante interpretación del «material jurídico que se presenta al conocimiento».

La trayectoria de KELSEN a propósito del tema de los conflictos entre normas registra una progresiva agudización de su concepción descriptivista de la ciencia jurídica, y un progresivo abandono de los residuos de una concepción constructiva e integradora de la interpretación científico-jurídica. Si la ciencia jurídica no está orientada a resolver problemas sino más bien a describir un derecho realmente existente, fruto de actos de voluntad llevados a cabo por multitud de criaturas humanas que adoptan sus decisiones sometidas a todo tipo de contingencias, entonces no hay razón para sobrecargarla con la tarea de inyectar en su objeto exigencias de racionalidad como coherencia y compleción.

Esto tiene su manifestación en un significativo aligeramiento de la norma fundamental. Como es sabido, KELSEN sostiene hasta el final de su vida, con unas u otras matizaciones, la doctrina de la norma fundamental como fuente última de validez del Derecho, y como presupuesto de la interpretación jurídica de la realidad. En este sentido podemos decir que sigue considerando que el sistema jurídico no es algo que meramente está ahí, dado al conocimiento, sino que es la construcción de un conocimiento orientado jurídicamente. Pero al descargar a última hora a la norma fundamental de la tarea de garantizar la unidad lógica del sistema, al concebirla como un presupuesto de una ciencia jurídica meramente descriptiva, KELSEN la descarga también de funciones constructivas. Del complejo algoritmo inicial, que operaba como filtro y configurador, «transformando» en sistema el «material dado al conocimiento», hemos pasado a una regla cuyo contenido es «una pura delegación», sin otra función que la de dotar de sentido normativo a las decisiones de un poder de creación de normas.

Al desprenderse al final de su vida de la tesis de la coherencia KELSEN no hace más que reforzar su adhesión al credo positivista. Lo extraño es que, en cambio, permanez-

126 Sobre el carácter contradictorio de la expresión «razón práctica», vid. RR 415-425. 
ca hasta el final aferrándose a la tesis de la compleción del sistema jurídico, esto es, a la tesis de la ausencia de lagunas ${ }^{127}$.

\section{CONSIDERACIÓN FINAL}

El objeto de este trabajo es el pensamiento de KelSEN, no la coherencia en el Derecho y el problema de las antinomias. He intentado identificar y explorar un nudo de tensiones que se encuentra latente en la concepción kelseniana del Derecho como sistema normativo y que se enreda en torno a la idea de coherencia. No pretendo en cambio ofrecer respuestas concluyentes a las cuestiones relativas al papel de la lógica en el Derecho, el lugar de la idea de coherencia en el Derecho, y la naturaleza y el status de las reglas de solución de antinomias, ni siquiera discutir sistemáticamente los argumentos de KELSEN sobre esas cuestiones ${ }^{128}$. Con todo, con el fin de concluir de algún modo, me limitaré a formular, de forma perentoria y sin mayor discusión, algunas consideraciones dispersas y nada concluyentes sobre el asunto, comentando algunas de las tesis de KELSEN.

1. Frente a la opinión del KELSEN tardío, opino que es injustificado negar que pueden darse relaciones lógicas de contrariedad y contradicción entre normas. Entre las modalidades deónticas «obligatorio», «prohibido» y «permitido» existen, creo yo, relaciones lógicas que se hacen evidentes una vez que las definimos tomando cualquiera de ellas como término primitivo y usando la negación. El desarrollo de la «lógica modal deóntica» tiene ahí su punto de partida. Ahora bien, si existen relaciones lógicas entre las modalidades deónticas, no veo por qué no podemos admitir que se dan también entre las normas que las establecen. En mi opinión es de sentido común que es lógicamente (y no sólo fácticamente) incompatible deber hacer algo y deber no hacerlo, y que dos normas que prescriben de ese modo son lógicamente (y no sólo teleológicamente) incompatibles. Los desarrollos experimentados por la lógica en las últimas décadas sugieren que el argumento de que no se trata de una incompatibilidad lógica porque la lógica sólo rige para los enunciados asertóricos, susceptibles de ser discutidos en términos de verdad, resulta simplemente dogmático: descansa en una visión restrictiva de la lógica, que ignora la posibilidad bien conocida de construir cálculos lógicos no dependientes del valor de verdad.

2. El último KELSEN tiene particular empeño en negar que los conflictos entre normas puedan caracterizarse como contradicciones. Creo, sin embargo, que tienen razón quienes opinan que no es posible identificar un conflicto de normas sin la idea

127 Vid. ATN, cap. 31.

128 De entre la literatura sobre el tema entresaco: S. PAULSON «Zum Problem der Normenkonflikte», ARSP, 66 (1980), y «On the status of the lex posterior derogating rule», en R. TuR y W. TwINNING (eds.), Essays on Kelsen, Oxford, Clarendon, 1986; M. G. Losano, «La dottrina pura del diritto dal logicismo al irracionalismo», estudio introductorio que acompaña la trad. italiana de ATN (Teoria generale delle norme, Einaudi, 1985); O. WEINBERGER, «Der normenlogische Skeptizismus», Rechtstheorie, 17 (1986), y «Logic and the Pure Theory of Law», en R. Tur y W. Twinning (eds.), Essays on Kelsen, op. cit.; I. WEYLAND, «Idealism and realism in Kelsen's treatment of norm conflicts», en R. TuR y W. TwINNING (eds.), Essays on Kelsen, op. cit.; T. MaZzarese, Logica deontica e linguaggio giuridico, Padova, Cedam, 1989; J. RuIZ MAnero, Jurisdicción y normas, Madrid, CEC, 1990, caps. III y IV; B. CELANO [«Norm Conflicts: Kelsen's View in the Late Period and a Rejoinder», en S. S. PAUlsOn y B. LiTsCHEWski PAUlSON (eds.), Normativity and norms. Critical perspectives on Kelsenian themes, Oxford, Clarendon, 1998]. 
lógica de contradicción ${ }^{129}$. Recuérdese cómo define KELSEN el conflicto entre normas en una de sus últimas formulaciones: «existe un conflicto entre dos normas cuando lo que una y otra establecen como debido es incompatible, y por eso el cumplimiento o la aplicación de una de las normas implica necesaria o posiblemente la violación de la otra» (ATN 99). Si, como parece obvio, KELSEN no está pensando aquí en necesidad o posibilidad empírica, ¿de qué otra cosa estamos hablando que de contrariedad o contradicción lógica? En algún momento KELSEN mismo parece aceptar en parte este punto:

«Constituye una aplicación del principio lógico de contradicción el que si alguien cumple una norma, no puede al mismo tiempo cumplir una norma que esté en conflicto con ella, es decir que la primera norma no puede al mismo tiempo ser cumplida e incumplida. Pues el principio de contradicción no significa otra cosa que cuando es verdad que una persona se comporta de un determinado modo no puede ser verdad que no se comporta de ese determinado modo. Esto es, sin embargo, la aplicación del principio de contradicción a dos enunciados sobre hechos del ser. Pero no está en cuestión la aplicabilidad del principio de contradicción a enunciados de ese tipo. Lo que está en cuestión y si ese principio es aplicable a normas» [RL 1483 y ss. (22 y ss.)].

De este pasaje parece inferirse que KELSEN mismo admite que no es posible identificar un conflicto entre normas sino en términos de contradicción lógica entre los enunciados referidos al cumplimiento de las normas. ¿Por qué entonces rechaza que el principio de contradicción sea aplicable a las normas? Ciertamente las normas carecen de valor de verdad, pero ¿no cabe establecer un cálculo lógico tomando validez como análogo de verdad, como de hecho parece proceder la lógica modal deóntica? Contra la tesis de que existen contradicciones lógicas entre normas, el KELSEN tardío alega que si el principio de contradicción fuera aplicable a las normas no existirían conflictos entre normas: para que haya un conflicto entre normas tiene que haber dos normas válidas, y aplicando el principio de contradicción, dos normas contradictorias no pueden ser simultáneamente válidas. Si admitimos que hay relaciones lógicas entre normas, tenemos que admitir también que los sistemas jurídicos son esencialmente coherentes, que la coherencia es una propiedad esencial de los sistemas jurídicos, y no meramente un desideratum. Éste es un argumento sagaz pero engañoso, que revela lo que yo creo que es un malentendido que perturba todo el tratamiento kelseniano de los conflictos normativos. Este argumento se apoya en uso confuso del término validez (Geltung), del que se sirve profusamente KELSEN, y probablemente se debilitaría si admitiéramos la distinción entre validez lógica y validez jurídica ${ }^{130}$. De dos normas que

129 J. RUIZ MANERO resume su conclusión en los siguientes términos: «Tanto si adoptamos la concepción bilética como si nos inclinamos por la concepción expresiva [...], la lógica se nos aparece como apta para cumplir, en relación con los conflictos entre normas, el mismo papel que cumple en relación con la inconsistencia entre aserciones: esto es, el de evidenciarlos» (Jurisdicción y normas, op. cit., p. 73). En términos parecidos se expresa B. CELANO: «Kelsen no parece haberse percatado de que el concepto de conflicto de normas depende crucialmente del concepto de contradicción lógica y que una contradicción lógica entre enunciados es el criterio por medio del cual puede entenderse que dos normas entran en conflicto» («Norm Conflicts: Kelsen’s View in the Late Period and a Rejoinder», p. 359).

130 Hace ya casi veinte años que J. DeLGAdo PINTO [en «Sobre la vigencia y la validez de las normas jurídicas», Doxa, 7 (1990), ahora incluido en Estudios de Filosofía del Derecho, Madrid, CEPC, 2006, vid., especialmente la larga nota 1] llamó la atención sobre el confuso uso que la filosofía del Derecho alemana hace del término Geltung aplicado a las normas: con él se designa en ocasiones la existencia actual de una norma en el mundo social, esto es, su vigencia, en otras su carácter valioso, en otras el hecho de reunir los requisitos establecidos por un orden jurídico para determinar su pertenencia al sistema. Muchas de las dificultades con 
regulan la conducta de forma incompatible — de forma contraria o contradictoriapodemos decir que desde el punto de vista lógico no pueden ser ambas válidas al mismo tiempo. Ahora bien, el hecho de que desde el punto de vista lógico dos normas incompatibles no puedan ser válidas al mismo tiempo no impide que desde el punto de vista jurídico ambas puedan ser válidas al mismo tiempo — por ejemplo, porque ambas han sido creadas por la autoridad competente, siguiendo el procedimiento previsto por el sistema-. Precisamente podemos caracterizar la antinomia como un conflicto entre dos normas que son ambas válidas desde el punto de vista jurídico pero que desde el punto de vista lógico no pueden ser válidas al mismo tiempo, porque son lógicamente incompatibles. Que dos normas sean jurídicamente válidas incluso si lógicamente no pueden serlo, no representa ningún problema conceptual si admitimos que validez lógica y validez jurídica son propiedades diferentes de las normas.

Lo que parece estar en juego en la negativa del último KELSEN a aceptar su posición inicial sobre la aplicabilidad del principio de contradicción a las normas son las condiciones de validez de las normas y los criterios de pertenencia al sistema: si el principio de contradicción fuera aplicable a las normas, entonces tendríamos que admitir (como de forma subrepticia admitía inicialmente KELSEN) que las condiciones de validez y los criterios de pertenencia al sistema no son puramente positivos. Esa objeción, creo yo, se alimenta del uso confuso del término «validez», al que acabo de referirme, y se disipa si aceptamos la distinción entre validez lógica y validez jurídica.

3. La existencia de incompatibilidad lógica entre dos normas jurídicamente válidas — vale decir, la existencia de antinomias — no representa ningún problema para la descripción de un sistema jurídico, pero sí desde luego para la aplicación del Derecho. En este sentido lleva razón KELSEN cuando, rectificando su propia posición sostiene que el enunciado: «En el sistema $S$ hay una norma que manda a y otra que prohíbe a» no constituye ningún problema lógico. Como información sobre un sistema jurídico ese enunciado no sólo está perfectamente en orden sino que, llegado el caso, puede ser verdadero. Pero la existencia de una norma que manda a y otra que prohíbe a representa, en cambio, un problema práctico: desde luego lo representa para el destinatario de la norma que, haga lo que haga, vulnerará una de las dos normas, y también para el órgano de aplicación del Derecho que tiene que decidir el caso dictaminando cuál de las dos formas de conducta es jurídicamente correcta y cuál de las partes implicadas en el caso tiene razón con arreglo a Derecho. En un sistema normativo institucionalizado, como es el Derecho, las antinomias persisten mientras no las resuelva el órgano competente ${ }^{131}$. El último KELSEN tiene razón cuando afirma que a propósito de ellas los juristas (en particular la llamada «ciencia jurídica») sólo pueden identificarlas e investigar sus posibles soluciones, pero carecen de autoridad para resolverlas de forma públicamente vinculante. Esta última es una tarea que compete al legislador mediante operaciones de cambio legislativo, y entre tanto a los que J. Raz denomina «órganos primarios» del sistema, fundamentalmente los tribunales, órganos encargados de es-

\footnotetext{
las que tropieza el traductor de KELSEN a la hora de verter al castellano expresiones como in Geltung setzen, in Geltung treten, geltendes Recht y otras por el estilo, desaparecerían si se siguiera la recomendación del profesor Delgado Pinto de utilizar vigencia y vigente en lugar de validez y válido. Esa recomendación podría ser oportuna en el caso que nos traemos entre manos.

131 A menos, obviamente, que existan normas positivas que establezcan de forma inequívoca cuál de las normas implicadas en una antinomia pierde validez jurídica.
} 
tablecer de forma públicamente vinculante qué rige como derecho y de decidir en un caso concreto qué debemos, qué podemos y qué no podemos hacer conforme al Derecho vigente. En todo caso, si admitimos que la ciencia jurídica no es, como afirma KELSEN, una ciencia puramente descriptiva, sino una empresa teórica orientada a resolver problemas jurídicos y en cierto modo referida a la práctica institucional de aplicación del Derecho, tampoco puede desentenderse de la discusión sobre la solución más satisfactoria de los conflictos de normas que detecta en el Derecho vigente.

4. La teoría del Derecho tiene ante sí la tarea de dar cuenta del hecho extraordinariamente perturbador de que en su trabajo de aplicación del Derecho los tribunales —al menos en un Estado de Derecho- están sujetos a deberes institucionales que les fuerzan a tratar el Derecho como si satisficiera exigencias de racionalidad —v. gr. coherencia y compleción - que no pueden esperarse de un sistema puramente dinámico. Es una obviedad que, en tanto que sistema normativo dinámico, el Derecho es propenso a generar antinomias y a albergar lagunas. Ahora bien, en tanto que sistema normativo institucionalizado dispone de órganos primarios - $v$. gr. los tribunalesque tienen encomendada la tarea de resolver unas y otras, y de resolverlas, además, con arreglo al Derecho vigente. Pero en un Estado de Derecho, bajo un régimen de imperio de la ley, los tribunales no sólo están obligados a decidir, sino que están obligados a fundamentar sus decisiones, y, por cierto, no invocando cualesquiera razones sino razones internas al sistema: no sólo tienen que resolver todos los casos, sino que tienen que hacerlo conforme a Derecho, porque cuando los ciudadanos acuden a los tribunales no tienen derecho simplemente a alguna decisión, sino precisamente a aquella que es conforme a Derecho. La irritante tesis dworkiniana de la respuesta correcta tiene su base en el hecho de que la tarea de aplicación institucional del Derecho está sujeta a la presuposición de que el sistema jurídico es completo — de modo que siempre hay una respuesta en términos del Derecho vigente - y coherente- de modo que siempre hay sólo una respuesta correcta. Integrar adecuadamente esa presuposición en una teoría del sistema jurídico que no minusvalore el carácter dinámico del Derecho (en el sentido kelseniano) es, en mi opinión, una tarea todavía pendiente para una teoría del sistema jurídico.

5. Si es verdad que los órganos primarios no son órganos de decisión discrecional, sino que deben resolver razonablemente e invocando razones internas al sistema, queda pendiente la cuestión de cómo han de afrontar los casos de antinomia. Desde luego cabe la posibilidad de que el sistema jurídico contenga reglas positivas suficientemente potentes para disolver los distintos tipos de antinomia. Pero ésta es una situación contingente. La cuestión interesante para la teoría del Derecho es si existen recursos razonables de los que puedan echar mano los jueces, en ausencia de reglas positivas efectivas. Los cuatro principios de interpretación que propuso KELSEN como reglas para la disolución de antinomias, no ofrecen una respuesta satisfactoria, porque, como ya he señalado, no están pensados tanto para resolver antinomias como para permitirnos describir como un todo coherente un sistema que contiene antinomias.

En la teoría del Derecho es moneda corriente referirse a las tres reglas tradicionales de disolución de las antinomias conocidas como lex posterior, lex superior y lex specialis. Su persistencia en el pensamiento jurídico descansa en el hecho de que no sólo son reglas razonables, sino que además son razonables en un sentido especialmente pertinente. Son reglas razonables, no por consideraciones externas, v. gr. porque 
proporcionen la solución más justa a un determinado caso, sino por consideraciones derivadas de la naturaleza y estructura misma del sistema jurídico y además son razonables por consideraciones relativas no a éste o aquél sistema jurídico en particular, sino a todo sistema jurídico en general, en la medida en que es un sistema jurídico dinámico (lex posterior), organizado jerárquicamente (lex superior), y en el que se reconoce a los órganos de producción de normas la capacidad de excepcionar en consideración a situaciones especiales (lex specialis). En este sentido, aunque no creo que quepa catalogarlas como reglas lógicas, me inclino a admitir que tal vez sean reglas universalmente válidas, en un sentido débil: son reglas razonables $y$ las razones por las que es razonable aplicarlas en un sistema jurídico valen para todos los sistemas. Es notorio que lamentablemente esas tres reglas no son enteramente eficaces para resolver las antinomias. Por consiguiente, si los tribunales tienen que resolver todas las antinomias, y tienen que hacerlo con arreglo a Derecho, el sistema jurídico tiene que disponer de otros elementos normativos.

\section{OBRAS DE KELSEN CITADAS EN EL TEXTO}

AS Allgemeine Staatslebre, Springer, Berlin, 1925 (para facilitar la localización de los textos en la trad. de L. LegAz, Teoría general del Estado, México, Nacional, 1979, se indica entre corchetes el lugar correspondiente).

ATN Allgemeine Theorie der Normen, Wien, Manz-Verlag, 1979.

BRO «Der Begriff der Rechtsordung» (1958), reimpre. en H. Kelsen, A. MERKL y A. Verdross, Die Wiener Rechtstheoretische Schule, Europa Verlag, etc., Wien, etc., 1968 [trad. «El concepto de orden jurídico», en Contribuciones a la teoría pura del Derecho, trad. de M. I. AzAretTo, Buenos Aires, Centro Edit. de Am. Latina, 1969 (orig. 1958)].

CT El contrato y el tratado (1943), trad. de E. GARCía MáYnEZ, México, Editoria Nacional, 1979.

D «Derogation», Essays in Jurisprudence in Honor of Roscoe Pound, Indianapolis/New York, Bob Merrill, 1962.

DL Derecho y lógica, trad. de U. Schmill Ordónez y J. CASTRo VAlLE de Recht und Logik (1965), México, UNAM, 1978.

GN «Die Grundlagen der Naturrechtslehre» (1963), sigo la versión publicada en AA.VV., Die Wiener Rechtstheoretische Schule, op. cit.

GT General Theory of Law and State, Cambridge (Mass.), Harvard Univ. Press, 1945 (entre corchetes, el lugar correspondiente en Teoría general del Derecho y del Estado, trad. de E. GarCía Máynez, México, UNAM, 1983).

HP Hauptprobleme der Staatsrechtslehre. Entwickelt aus der Lebre vom Rechssatze (1911), 2. ${ }^{a}$ ed., Tübingen, Mohr, 1923 (trad. de W. Roces de la 2. ${ }^{a}$ ed. alemana, Problemas capitales de la teoría jurídica del Estado, México, Porrúa, 1987).

NPR Naturrecht und positives Recht. Eine Untersuchung iheres gegenseitigen Verbältnisses, Sonderabdruck aus der Internationalen Zeitschrift für Theorie des Rechts II (19271928), Brünjn, R. M. Moherer, 1928.

PG «Die philosophischen Grundlagen der Naturrechtslehre und des Rechtspositivismus» (1928), tomado de AA.VV., Die Wiener Rechtstheoretische Schule, Europa Verlag, Wien, etc., 1968. 
RL «Recht und Logik» (1965), sigo la versión publicada en AA.VV., Die Wiener Rechtstheoretische Schule, op. cit. (trad. española de U. SCHMILl OrdóÑEZ y J. CASTRO VALLE, Derecho y lógica, México, UNAM, 1978).

RR Reine Rechtslebre, Wien, Deuticke, 1960 (se trata de la segunda edición de la Teoría Pura del Derecho; para facilitar la localización de los textos en la trad. R. J. VERNENGO, México, UNAM, 1979, se señala entre corchetes el lugar correspondiente).

TP1 La teoría pura del Derecho. Introducción a la problemática cientifica del Derecho, trad. de C. Cossio (de la 1. ${ }^{a}$ ed. de la Reine Rechtslebre de 1934), 2. ${ }^{a}$ ed., México, Editora Nacional, 1979.

TP2 Teoría pura del Derecho, trad. de M. Nilve y N. Cabrera, Buenos Aires, EUDEBA, 1960 (versión española de la edición francesa de 1953 de la Teoría Pura). 